\title{
Child Poverty and Compulsory Elementary Education in India: Policy Insights from Household Data Analysis*
}

\author{
D.P. Chaudhri \\ Monash University
}

\author{
Raghbendra Jha \\ ASARC, ANU
}

\footnotetext{
All correspondence to:

Prof. Raghbendra Jha,

Australia South Asia Research Centre,

Arndt-Corden Department of Economics,

College of Asia and the Pacific,

Australian National University,

Canberra, ACT 0200, Australia

Phone: + 6126125 2683, Fax: +61 261250443

Email: r.jha@anu.edu.au
}

*We are grateful to Hai Anh La for excellent research assistance. The usual caveat applies. 


\section{ABSTRACT}

Children ( under 15 years of age) growing up in poor and/or nutritionally deprived households also live with a number of layers of deprivations that stifle their freedom to actively participate in and benefit from elementary school education. Lack of health care, limited access to quality schooling and opportunity cost of participation in education are some of these layers. Human Development Report 2010, using Oxford University's newly developed Multidimensional Poverty Index, adds more dimensions to poverty measures over and above those of the Indian Planning Commission's (2009) new measure or absolute poverty used in this paper. These enrich our understanding but do not directly deal with children growing up in absolute poverty and non- participation in schooling. This issue can be meaningfully explored with household as the unit of analysis.

The paper uses household level data for 2004-05 (NSS 61st Round) and 1993-94 (NSS 50th Round) for India and also major states to analyze these issues. We start with the size of child population, changing share of states and uneven demographic transition in India (particularly the movement in Total Fertility Rates across Indian states) during 1961-2001. Changes in the number of children and the household size in very-poor, poor, non-poor low income and nonpoor high income households from 1993-94 to 2004-05 are analyzed within the crosssections and also between the two cross-sections. Participation in education, and nonparticipation separated as child labor and Nowhere (neither in schools nor in labor force) by poverty status at the all-India and the state levels are reported and commented upon.

Changes in magnitudes \& proportions of children in poverty in India and across states during 1993-94 \& 2004-05 are presented and the share of some states in these magnitudes is highlighted. The determinants of non-attendance in schools (i.e. child being in the labor force or 'no-where') for 5-14 year olds are analyzed using formal econometric models - Probit with binary variables and also Multinomial Logit Models. The results are robust and confirm our descriptive analysis. Finally, broad features of The Free and Compulsory Elementary Education Act, 2009 (Law w.e.f. April, 2010) are reported and linked to the policy implications of our empirical findings for meaningful implementation of the Elementary Education Law. Potential usefulness of Unique ID in delivery of child focused services and monitoring is also highlighted.

EL Classification Codes : I21, J11, J13, J16, J22,

Keywords:

Total Fertility Rate, Child poverty, Elementary education, School non-attendance, India. 


\section{Introduction}

The period between 1993 and 2005 has been one of major policy shifts and reforms in India. Growth rates of total and per capita income have accelerated. Population growth and absolute poverty have been declining. Uneven pace and patterns across states and households have accentuated pre-existing dualistic patterns and inequalities. This paper reports analysis of household data from National Samples Surveys for the years 1993-94 and 2004-05 from the perspectives of child poverty and participation in or exclusion from school education. The findings on interstate and inter-household disparities have immediate relevance for policies aimed at implementing the Free and Compulsory Elementary Education Law of 2010.

The paper is organized as follows. Section II is devoted to the changing size and shares of child population in India during 1961-2001 and its driver with projections to 2026, unequal demographic transition across states of India. In section III we comment on household size and number of children in poor and non-poor households, across states in 1993-94 and 200405. Section IV deals with magnitudes and changing shares of children in poverty across states of India. Section V profiles elementary education by poverty status at the all-India level whereas section VI does this at the level of individual states. Section VII analyzes the determinants of non-attendance in schools (i.e. child being in the labor force or 'nowhere') for 5-14 year olds based on the results of Probit and Multinomial Logit Models estimations. Section VIII highlights the basic features of Free and Compulsory Elementary Education Law and implications from our findings for its meaningful implementation. Section IX deals with the Unique ID and its potential usefulness in efficient delivery and monitoring progress of child focused poverty reduction and education efforts. Summary and Conclusions in section $\mathrm{X}$ brings out the need for policy focus on children in poverty for implementation of the Elementary Education Law and also necessary changes in India's poverty elimination efforts.

\section{Child Population, States Shares and Demographic Transition}

Child population (5-14 years) in India increased from 114 million in 1961 to 243 million 2001. Based on our estimate of child population for 2004-05, based on NSS data, and experts committee's projections to 2026 we find that child population in India had peaked at 243 million in 2001. Four major states of India, namely Uttar Pradesh (UP), Bihar, Maharashtra and Madhya Pradesh (MP), accounted for 38.9\% of child population in 1961 . Their share increased to $48.4 \%$ in 2001. Our estimate and expert committee projections to 2026 suggest 
that the share of these four states will keep rising till 2026 when it would reach over $52 \%$ of child population. The details can be seen in Figure 1 and actual data in Table A-1. Child population of Bihar increased from 7.4 million in 1961 to 29.5 million in 2001 which is fourfold increase during this 40 year period. In UP it increased from 18.9 million in 1961 to 46.9 million in 2001. In contrast child population in Kerala increased from 4.7 million in 1961 to just 5.6 million in 2001 and in Tamil Nadu it increased from 8.1 million to 11.6 million during the same period. Figure 1, clearly demonstrates that pace and pattern of increase in child population during this 50 year period has been very uneven in different states of India. States in 'virtuous' spiral, as Chaudhri (1996) demonstrated have a slower rate of growth of child population and those in ' vicious spiral' had a much faster rate of growth of child population (Figure 2 and Table A2). The drivers of this differential growth have been investment in developmental efforts, elementary education, infrastructure and faster structural change of the economy of the states in virtuous spiral. Reverse is true for the states in vicious spiral.

Figures 1 and 2 here

The pace of demographic transition mainly depends on speed of economic change and investment in social infrastructure, in particular elementary education (Caldwell 1990, 1998, Chaudhri and Nyland 2002, Chaudhri 1997). This is now part of conventional wisdom, resulting from extensive research, the efforts of UN Population \& demographic reportings and UNICEF's studies. The key driver is total fertility rate (TFR) and its change over time. Infant mortality rates are closely related to it. We have reported these in Figure 2, and detailed data in Table A2. Total fertility rate in India was 6.1 in 1961. It peaked at 6.5 in 1971 and has been declining steadily since then. In 2001 TFR in India was 2.9. In states like Bihar, Jharkhand, UP, Gujarat and Rajasthan it was above the national average with Bihar having the highest TFR at 7.9. In 2001 more than half the Indian states had TFR lower than the national average of 2.9. A TFR of 2.1 would result in stationary population and an even lower rate, as in Kerala and Tamil Nadu, results in declining child population. Bihar, Jharkhand, UP, Rajasthan, and MP continue to have a TFR above 3.0 whereas the national average is 2.9. This can be seen from Figure 2 and also Table A2. The expert committee projections to 2026 are based on projected changes in total fertility rates, women in reproductive age group, and infant mortality rates in different states of India. From Figures 1 and 2 we can surmise that it is obvious that more than half the new investments in delivering free and compulsory 
elementary education at an acceptable national standard will have to be directed to four major states of India, namely UP, Bihar, Maharashtra, and MP which account for $49 \%$ of child population.

\section{Children in Poor and Non-poor households in India}

Uneven demographic transition across India presented above dealt with state and national level aggregations. These were based on different rates of change over time in TFR across states. We now examine the same question through an analysis of household data for two cross-sections 11 years apart. We first comment on the number of children (in the age group 0-14 years) in households of different poverty categories. Households are divided into four groups: (i) Very Poor: households with monthly per capita expenditure (MPCE) less than half the official poverty line, (ii) Poor: Households with MPCE less than the poverty line but more than half the poverty line, (iii) Non-poor Low: Households with MPCE more than the poverty line but less than twice the poverty line, and (iv) Non-poor High: Households with MPCE more than twice the poverty line. Results comaparing the average household size and the average number of children in these four categories of households for 1993-94 and 2004-05 are given in Figure 3 and Table A3.

Figure 3 here

Chaudhri and Wilson (2002) had done a similar analysis to study child labour. Tilak (1996) had done so with 1987-88 data for non-participation in schools and Ray (1999) reported relationship between poverty and household size. Chudgar (2010) analysed only female headed households. Rastogi et.al.(2008) presented aggregates on children in poverty in South Asia at a UNICEF organised regional workshop. We go further and compare these differences within a sample across four groups by MPCE and also between samples that are 11 years apart.

In 1993-94 the average household size among the very poor was 5.8 and 2.9 children on average were living in this household. The average household size among the poor was 5.6 and 2.4 children were living in such a household. The household size of the non-poor low was 5.0 and only 1.7 children were living in it. Unsurprisingly, households in the non-poor high group had an average family size of 3.9 and only 1.0 child was living in it. The differences across groups with pairwise comparisons are statistically significant at 1 percent level of significance. In 2004-05 the average size of household among the very poor declined 
to 5.5 and the number of children living in it declined to 2.6. Among the poor the household size increased to 5.8 and number of children living in it remained unchanged at 2.4. Among the non-poor low the average size increase to 5.1 and the number of children living in it remained unchanged at 1.7. Among the non-poor high the average size remained unchanged at 3.9 but the number of children living in it declined to 0.9 . The differences across subgroups, when not zero, in the number of children in the households are statistically significant at 1 percent. The differences in the means in pairwise comparisons, when not zero, during the two periods are also statistically significant at 1 percent.

This gives us a very interesting pattern of uneven demographic transition among these four groups of households within a cross-section and also the change from 1993-94 to 2004-05. First, the number of children in the non-poor high group has declined over this period and is now less than one at 0.9 , giving a very low dependency ratio. The number of children in nonpoor low expenditure group at 1.7 and among the poor and very poor at 2.4 and 2.6 respectively are increasing monotonicaly with decline in household expenditure. The inescapable inferences that the poor have larger family size, larger number of children in their households and also have higher dependency ratios compared with the non-poor have relevence for policies on child poverty reduction and also poverty reduction for faster demographic transition among poorer households across states. Implementing the Compulsory Education Law in earnest and focusing on this subgroup as a priority will have high social benefits.

\section{Child Poverty Across Indian States}

In 1993-94, 121.7 million children (0-14 years) were living in absolute poverty. This number declined by 17.7 million to 103.9 million in 2004-05. In terms of proportions, $43.4 \%$ of children were living in absolute poverty during 1993-94 and this declined to $31.7 \%$ in 2004-05. Concentration of child poverty in the four states that account for half the children in India is rather startling as can be noted from Figure 4 and Table A4.

Figure 4 about here

In section II we had pointed out that only four states of India, namely UP, Bihar, Maharashtra, MP account for $49 \%$ of child population 5-14. These four states also have a concentration of child poverty which is even higher than their proportional share in child 
population. Three other states, West Bengal, Orissa and Rajasthan have child poverty of more than 5 million children in each one of them. All the other states of India account for a much smaller number. Himachal Pradesh and Jammu and Kashmir have the lowest number and proportion of children living in absolute poverty. Surprisingly, this is not true for Kerala anymore. In Figure 4 we have shown the shares of child population in the groups 0-4, 5-9 and 5-14 separately mainly because the policies required for each of these sub-groups are different. While dealing with compulsory elementary education laws the age-group 5-14 years is relevant. For dealing with child labour only and middle schools, the relevant age group is 10-14 because we know that over $95 \%$ of child labour comes from this age group. For dealing with infant and child development during preschool years, age-group relevant for Anganwaries is under five years of age. These subdivisions also tell us something about the potential demand for compulsory elementary education in the primary and middle school stages.

In Figure 4, we have presented the actual number of children in absolute poverty in two separate panels for each state, the left one dealing with 2004-05 and the right one dealing with 1993-94. This is done to examine the change in number of children in absolute poverty in different states of India by different age groups during these two periods. Decline in child poverty over this period for India as a whole is also reflected in all the states with a small child population, except Delhi. Maharashtra, even among the large child population states, is a glaring exception. This is brought out clearly in Figure 5 and Table A5.

Figure 5 about here

We note that in Maharashtra the absolute number of children living in poverty increased by over 2 million over 11 years. Increase in Rajasthan and Orissa as well as MP has also been large. Increase noted in Kerala, Jammu \& Kashmir, Haryana and Delhi, though small, is a cause for alarm. The largest decline noticed between these two periods was in West Bengal, UP, Andhra Pradesh, Karnataka, Tamil Nadu, Gujarat, and Punjab. Decline of child poverty in Bihar has been disappointingly small.

Increasing child poverty in the age group 10 to 14 in Maharashtra, Rajasthan, Orissa, MP and Delhi has serious implications for potential increase in child labour and potential violation of Compulsory Elementary Education Laws unless corrective policy measures are taken.

Policies dealing with overall poverty reduction, child focused poverty reduction, provision of 
Anganwaries and implementation of elementary education laws to be successful would need to get commitment from and cooperation of six major states of India, namely UP, Bihar, MP, Maharashtra, West Bengal, and Orissa. These states would also require major inputs of financial, organisational and institutional resources for meaningful implementation of the new elementary education law.

\section{Elementary Education by Poverty Status at the all-India Level}

Following the classification of households by poverty status discussed in section III, we report on the schooling status of children in the age group 5-14 years in Figure 6 and Table A6, separately for each of these four groups. Children in each of the groups are divided into those who are attending school, those who are in full time work (child labour) and those who are doing neither, we call Nowhere children. Consistent patterns observed in household size and number of children observed above is evident in school attendence, incidence of child labour and proportions of Nowhere children as well.

Figure 6 about here

Out of a total child population of 223.5 million in 2004-05, 2.9 million children or $1.3 \%$ were ultra poor, 66.7 million children or or $29.8 \%$ were poor; 124 million children or 55.48 $\%$ were in the non-poor low category, and 29.9 million children or $13.38 \%$ were in the nonpoor high category. Thus, the proportion of children (31.1 per cent) who are poor is greater than the proportion of the total population that is poor (28.7 \% for the rural sector and $25.9 \%$ for the urban sector, according to Himanshu (2007)). This higher incidence of poverty among children is further reinforced when we consider non-attendance in schools. In the population as a whole while $82 \%$ of children aged 5-14 are in school only $71 \%$ of children in ultra-poor households and $72 \%$ in poor households are in schools. The proportions for children in non-poor low and non-poor high households are much higher (85\% and 95\% respectively). Hence, in a Business as Ususal scenario a greater proportion of children from poor households will face lives without education and hence, possibly, perpetuation of intergenerational poverty than children from non-poor households. As expected, the incidence of child labor and of children being 'nowhere' is much higher among poor hosueholds than among non-poor households. From the vantage point of implementation of the Compulsory Education Law 2010 an important implication is that these children will need bridging courses before they can be absorbed into the regular education stream. 
A comparison of the pie charts for 2004-05 with those for 1993-94 suggestes that participation in schooling has improved for each of the four groups. In India total child population increased from 169 million to 226 million during this period. Percentage attending schools increase from $68 \%$ to $83 \%$; child labour decline from $5 \%$ to $2 \%$ and proportion of nowhere children decline from $27 \%$ to $15 \%$. This is a sea change from the dismal performance of the first four decades of elementary education effort. However, almost one third of children growing up in poor households continue to be stifled. These all India figures conceal diversity across States and much larger than proportionate share of children in poverty in the states still in the vicious spiral of poverty.

\section{Elementary Education Across States by Poverty Status}

States with large concentrations of children in poverty, viz., UP, Bihar, MP, Maharashtra, West Bengal, Orissa, and Rajasthan also have a higher proportion of poor either in full-time child labour or nowhere as can be seen from Figure 7P. Reverse is true for Himachal Pradesh, Kerala, Andhra Pradesh and Tamil Nadu where the proportion of children even from households in absolute poverty attending school is between 85 and $90 \%$. In contrast the above-mentioned states in vicious spiral have a school attendance rates of between 54 and $73 \%$ for children from households in absolute poverty.

Figure 7P \& NP about here

We have noted above that one in three children of India live in absolute poverty. Despite this handicap about $70 \%$ of children in poverty attend schools. For states in virtuous spiral, schooling is at the higher end of 85 to $90 \%$, while those in vicious spirals have school attendance in the range of 54 to $73 \%$. A part of this can be explained by slow demographic change resulting in larger concentration of child population presented above. The main driver, however, has been failure of public policy to address issues of educational and overall development of the states caught in the vicious spiral .A bi-modal distriution of states is unmistakable. A policy implication for serious implementation of the Compulsory Education Law 2010 is that focusing on states in the vicious spiral will require a big push in financial inputs, restructuring of institutions and enhanced monitoring and evaluation of educational efforts in these states. 
School participation rates of children from nonpoor households, reported in Figure 7NP, are significantly higher than those from households in absolute poverty. Bihar has the lowest participation rate at $77 \%$, and UP and Rajasthan have participation rates at about $82 \%$. In all other states the rates are close to $90 \%$ or higher. Implementation of the new Education Law, to be effective, has to take cognizance of poverty and non-poverty groups differences and also issues of non-participation even among the non-poverty groups in the States in vicious spiral mentioned above. This is easily verified from Figure 7P and 7 NP. See also Table A7.

Differences in attendance rates in rural and urban areas of different States present a mixed picture. Participation in education, in states in virtuous spiral, continue to have sharp differences between poor and nonpoor groups but not between rural and urban areas. In contrast, states in vicious spiral, present a mixed picture. Thus, in rural UP $70 \%$ of children in poverty attend school while $81 \%$ of children of nonpoor attend school. In contrast, in urban UP only $67 \%$ of children in poverty attend school while $88 \%$ of nonpoor children attend school. It is noteworthy that rural urban difference favours the urban areas for the non-poor but reverse is true for the poor in UP. In contrast, in rural Bihar school participation rates are lower for poor as well as nonpoor compared to their counterparts in urban Bihar. These results are reported in Figure 7UP, 7NUP, 7RP and 7 RNP.

\section{Figures 7UP, 7NUP, 7RP and 7 RNP about here}

Change in children's participation in schooling, child labour and nowhere children from 1993-94 to 2004-05 in major states of India is presented in Figures 8, 8R and 8U. See akso Table A8.

Figures $8,8 \mathrm{R} \& 8 \mathrm{U}$ here

School participation rates have improved substantially in all states except Tamil Nadu. Child labour has declined in all states except Kerala where it has increased marginally. Number of nowhere children has increased in Bihar, Jammu and Kashmir, and Kerala, while it has declined in all other states. In rural areas child labour has increased in Jammu and Kashmir and Kerala but has declined in rural areas of all other states. In urban areas of many states the change is a cause for concern and requires appropriate policy attention. Child labour increased in urban Bihar, Gujarat, Jammu and Kashmir, MP, Rajasthan and UP from 199394 to 2004-05. The absolute number of nowhere children increased in urban Jammu \& Kashmir and Rajasthan while it declined in all other states of India. Decline in number of 
children in labour force and nowhere category in UP and Bihar, in rural as well as urban areas, has been substantial. Consequently, school attendance rates, at least nominally, have shown substantial improvements in these two states. ProbeII team(2010) has commented on this change. Overall, improvement in School participation is unmistakable for the non poor and also for the poor, but at a lower rate. However, partly due to increase in child population and partly due to the dynamics of development, increase in child labour and nowhere children in some states is a cause for serious concern.

\section{Determinants of non-particpation in Schools}

We now try to understand the determinants of non-attendance in school. Two broad classes of econometric models are estimated. In the first we use a probit model with the binary variable being at least one child in the age group 5-14 years from the household not being in school, i.e., these children are either in the labor force or 'nowhere'. In the second case we use a multinomial model of the child being in school, in child labour or 'nowhere'. Our broad conclusions are that states with high concentration of child poverty are more likely to have children out of school. The dependency ratio also matters as the higher the number of children in the household the greater the likelihood that a child would be out of school. Per capita expenditure, share of health and education in household expenditure, and whether the household is female and whether he/she is illiterate have the anticipated impacts. Social factors like being SC or ST are still important.

\section{The Probit Model}

There is a latent or unobserved, variable $\mathrm{y}^{*}$ which is generated from a familiar looking model:

$\mathrm{y}^{*}=\beta^{\prime} \mathrm{x}+\mathrm{u}$

where $\beta$ is a K-vector of parameters, $x$ is a vector of explanatory variables and $u \sim N(0 ; 1)$ is a random shock. We observe $y=1$ if $\mathrm{y}^{*}>0$ and $\mathrm{y}=0$ otherwise.

It is easy to show that $\operatorname{Pr}(\mathrm{y}=1)=\Omega\left(\beta^{\prime} \mathrm{x}\right)$. This gives us the likelihood for both cases $\mathrm{y}=0$ and $y=1$. Assuming the observations are i.i.d. it is straightforward to construct the sample log likelihood. This can be maximized using standard nonlinear maximization algorithms in STATA. A reference group (typically $\mathrm{y}=0$ ) is omitted from the estimation. It is well-known (Wooldridge, 2006) that marginal effects and not coefficients are relevant for analysis. 
Various versions of the Probit model using robust techniques are estimated for 1993-94 and 2004-05 and results are robust across various models estimated. Hence, we report results on the most general model with interaction effects. A summary of these results and statistical tests for the significance of differences in the coefficients across the two sample periods are shown in Table 1

\section{Table 1 here}

In both time periods the larger the number of children aged 0-4 and 5-14 in the household the greater the probability that a child would not be in school. However, this impact is significantly lower in 2004-05 for children aged 5-14. Similarly, the greater the proportion of girls aged 0-4 as well as 5-14 the greater the likelihood of a child not bein in school. However, this impact is significantly lower in 2004-05 for girls aged 5-14. In both sample periods a female headed houshold has a lower probability of a child being out of school and the differnce of the reponse across the two time periods is not significant. As expected the higher the education share of household expenditure the lower the probability of a child being out of school. However, the strength of this is significantly lower in 2004-05. Since education and health expenditures compete in household budgetary allocation, the higher the share of health expenditure the greater the likelihood of a child being out of school but the strength of this response is not significantly different in 2004-05 as compared to 1993-94. Again, as expected, the higher the per capita expenditure the lower the probability that a child will be out of school. However, the strength of this reponse has fallen significantly over time. If the household head is illiterate there is a greater chance of a child not being in school. However, the strenght of this response does not vary significantly over time. The interaction of illiterate household head with share of education in housheold expenditure is negatively related to the likelihood of a child being out of school. However, the strength of this reponse falls over time. The interaction of illiterate household head with share of health in housheold expenditure is negatively related to the likelihood of a child being out of school, but the coefficients are small in both sampe periods. Further, the strength of this reponse falls over time. The interaction of illiterate household head with pre capita household expenditure is negatively related to the likelihood of a child being out of school. However, the strength of this reponse falls significantly over time. Disturbingly, in both periods ST housheholds have a higher probability of a child being out of school and the differnce increases significantly over time. Interaction effects of ST with other characteristics are insignificant except for its interactions with health and per capita household expenditure, which are significant in 1993- 
94 only, and reduce non-participation in schools. Differences of these coefficients over time are negative and signficant. Similarly, SC households are less likely to send their children to school. The interaction of SC with health share of total expenditure is significant for 1993-94 only and raises the likelihood of a child not going to school. The difference in this coefficient over time is insiginficant. In 1993-94 SC interacted with per capita expenditure lead to lower likelihood of a child not going to school and over time this difference is lower and significant. State dummies (relative to Gujarat) are positive and significant for those states where demographic pressures are most severe. Thus, children in Tamil Nadu are morel likely to attend school whereas those in Uttar Pradesh are less likely to attend school than children in Gujarat. Relative to Gujarat whereas the influence of UP has only been exacerbated over time that of Tamil Nadu has fallen. Children in rural India are less likely to not attend school in 2004-05. The diagnostics of the estimated equations are strong.

\section{The Multinomial Logit Model}

We further refine the analysis of factors underlying not being in school by considering the three categories that a child aged 5-14 years could be in: in school, in the labor force and 'nowhere'. To analyze the determinants of these we turn to estimating a multinomial logit model.

For Category $(\mathrm{Y}=\mathrm{m})$ the multinomial logit model is stated as

$$
P(Y=m)=\frac{\exp \left(Z_{m}\right)}{1+\sum_{h=1}^{M} \exp \left(Z_{k}\right)} \text { where } \mathrm{m}=1,2 . .
$$

For the Reference Category, i.e., $(\mathrm{Y}=0)$ the multinomial logit model is stated as:

$$
P(Y=0)=\frac{1}{1+\sum_{h=1}^{M} \exp \left(Z_{k}\right)}
$$

Here $\mathrm{M}=$ number of explanatory variables used in the analysis. Once again, Wooldridge (2006) argues that marginal effects are more meaningful than coefficients.

\section{Table 2 here}

Table 2 presents results for the multinomial estimation for being a child worker and being 'nowhere' with 'being in school' as the base case for 1993-94 and 2004-05. The results are again quite robust across different estimation techniques. 


\section{Results on Child Labor}

In both time periods the higher the number of children in the age group 0-14 the lower the probability that a child would be working. However, this difference falls over time. The proportion of girls aged $0-14$ to children aged $0-4$ is practically insignificant. The higher the number of children in the age group 5-14 years the greater the likelihood of a child being in the labor force and there are no significant differences in this over time. However, the higher the ratio of girls aged 5-14 among all children aged 5-14 within the household the lower the likelihood of a child being in the labor force. The difference between the two years in regard to this is positive and weakly significant. Thus, it appears that girls are, ceteris paribus, less likely to enter the labor market. Female headed households were more likely to send children into the labor force in 2004-05 but not in 1993-94. Higher per capita expenditure does not, in general, significantly affect the likelihood of a child entering the labor force. The higher the share of education in household expenditure the lower the likelihood of the household sending a child into the labor force and this difference has grown over time. However, the share of health in total expenditure does not significantly affect the likelihood of sending a child into the labor force. Households headed by an illiterate person are more likely to send a child into the labor force and this effect does not change significantly over time. The likelihood of a child being sent into the labor force is significantly affected by households with higher per capita expenditure and headed by an illiterate person in 1993-94 but not in 2004-05. The interaction of illiterate household head with proportion of expenditure on education has a negative impact on sending children into child labour and the difference over time is positive and significant. The effect of the interaction of illiterate household head with health share of total expenditure on child labour is positive and significant in 1993-94 but insignificant in 2004-05. In both cases the magnitude of the coefficient is small. The fact that a household is ST has an insignificant effect on any one of its children being in the labour force. ST interacted with health share of total expenditure had a positive but small impact in 1993-94. ST interacted with per capita expenditure had a negative impact on the probability of a child being in the labour force and this impact changed only insignificantly over time. All other ST related variables were insignificant in both time periods. SC households had a positive and significant impact on child labour in 1993-94 but this effect was insignificant in 2004-05. SC interacted with per capita expenditure was negative and significant for 1993-94 and SC interacted with health share of expenditure was positive and significant (but small in magnitude) in 1993-94. All other SC related variables were 
insignificant, Relative to Gujarat UP had a higher probability of a child being in the labour force and Karnataka had lower probability for both time periods with the latter falling significantly over time. .

Rural households are less likely to send their children into the labor force but this effect has fallen over time.

\section{$\underline{\text { Results on being 'nowhere' }}$}

These results are presented in the lower panel of Table 2 and are once again quite robust with respect to the estimated equation.

The larger the number of children in the age groups 0-4 and 5-14 the higher the probability that a child will be "nowhere". Differences over time are insignificant for the age group 0-4 but negative and significant for 5-14 year olds. The larger the proportion of girls the greater is the likelihood of a child being 'nowhere' but this effect has fallen over time. Thus girls who are not in school are more likely to 'nowhere' and less likely to be in the labor force. Female headed households and households having higher per capita expenditures are less likely to have a child in the 'nowhere' category. The difference in the second effect is negative and significant. As expected, the higher the share of expenditure in the household's expenditure the lower the likelihood of a child being 'nowhere'. This effect falls over time. Also as expected the higher the share of health in total expenditure the greater is the likelihood of a child being nowhere. However, the difference over time is insignificant. A household where the head is illiterate has a greater likelihood of children being nowhere and the difference in this impact over time is insignificant. In both periods illiterate head interacted with education share of total expenditure lowers the likelihood of a child being nowhere and this effect rises over time. In 2004-05 illiterate head interacted with health share of total expenditure had a negative impact on a child being nowhere whereas this effect was positive in 1993-94. The difference between the coefficients in the two time periods is negative and significant. Illiterate head interacted with per capita expenditure has negative and significant impacts on the likelihood of a child being nowhere in both time periods. In 1993-94 a ST household had greater likelihood of having a child being nowhere; in 2004-05 this effect was insignificant. Other ST related variables were insignificant except for ST interacted with health share of total expenditure and ST interacted with per capita expenditure which were positive and significant and negative significant but only 1993-94. SC 
households had a greater likelihood of having a child in the nowhere state, but this effect has fallen over time. SC interacted with share of education in expenditure has, as expected, a negative impact in both time periods and the difference in the two responses is insignificant. SC interacted with health share of total expenditure has a positive impact but only in 199394. Other SC related variables are insignificant. As compared to children from Gujarat those from West Bengal, Bihar, Uttaranchal and some other states have higher likelihood of being 'nowhere.' In contrast children from Maharashtra, Andhra Pradesh, Mizoram and some other states have lower likelihood of being 'nowhere' than those from Gujarat. ${ }^{1}$ Children from rural households are less likely to be 'nowhere' as compared to those from urban households.

\section{Free and Compulsory Education Law 2010.}

For the first time in the history of India, all children in 6-14 age group have legal rights to free and compulsory elementary education up to grade VIII. The Rights of Children to Free and Compulsory Education Act 2009 has become law from 1 April 2010. ${ }^{2}$ The new law is a game changer. It requires all state parties to ensure a national system of education with minimum acceptable standards and enforceable neighborhood school admissions. All private/elite schools are required to enroll $25 \%$ of children from deprived groups in their total admissions. They will be re-reimbursed at the rate of average cost. Salient features relevant to children living in poverty, we have been discussing, are summarized below:

The National Commission for Protection of Child Rights has to monitor progress of the proposed institutional arrangements. State Commission for Protection of Child Rights have

\footnotetext{
${ }^{1}$ To check for robustness two additional specifications of the probit and multinomial logit regressions were run. In the first, children aged $0-4$ and girls aged $0-4$ as a proportion of children aged $0-4$ in the household were also included in the regressions. In the second the number of children aged $0-14$ and proportion of girls aged 0-14 in total number of children aged 0-14 in the household were included and children aged 5-14 and proportion of girls aged 5-14 in total number of children aged 5-14 were dropped from the set of independent variables. The results were broadly similar to those reported in Tables 2 and 3. These results are not included here to conserve space but are available, upon request, from the corresponding author.

${ }^{2}$ The Gazette of India, No 39 dated 27 August 2009, Ministry of Law and Justice, Government of India, New Delhi contains details of the bare Act. It has been extensively commented in India and internationally. See Chaudhri (2010) as an example. The Act has been a very long time in coming. For the background of its evolution see Naik $(1975,1980)$, Naik et al. (1952), Education Commission Report (1966). For critical comments on slow evolution, see Dreze \& Sen (1995, 1997), Weiner (1991), Rustagi (2008, 2009), Probe Report (1999; 2011 forthcoming), Mehrotra (2006), Govinda (2008) among many others. On legal aspects see Bhatt (2005).
} 
been asked to monitor progress in their respective states and reported to the National Commission. Every school is required to have a school management committee to monitor the working of the school; prepare a school development plan; monitor the utilization of the grants received from the appropriate government are local authority; and perform such other functions as may be prescribed. All stakeholders would have representation in the committee with at least $50 \%$ of membership drawn from women. Similar institutional arrangements have been proposed at the local government, district and state levels. The duties of the teachers, their qualifications, up gradation of their training and their role are being specified. Similarly, a minimum national curriculum has also been suggested. These are all detailed in different schedules of the Act. The government is required to have modifications to the schedules, if any, discussed in the Parliament.

No child shall be refused admission, and shall be admitted to the class appropriate to her age. The school is required to provide the necessary extra educational support to the child so as to enable her to catch up with the rest of the class. The teacher pupil ratio at the primary level has been lowered to 1:30 in primary sections and 1:35 in upper primary sections. All schools are required to have a school library with newspapers, magazines and books, play materials, games and sports equipment. State is to provide facilities and it is the responsibility of local self-government to provide for education of incoming migrant children.

The National Commission for Protection of Child Rights and State Commissions along with national and state advisory bodies have been given responsibility for tracking performance of the Act .Most of these provisions were recommended by the National commission on education 1966. Naik, who had been member secretary of the commission (1964-66), summarizes the role of education as stated in the report,

The new education, in the commission's view, should be based on a deep and widespread study of science and technology; should cultivate a capacity and willingness to work hard and be closely related to productivity; should strengthen social and national integration and help to create a more just and egalitarian social order; should consolidate democracy as a form of government and help us to adopt it as a way of life; and should help us to strive to build social, moral and spiritual values. ${ }^{3}$

\footnotetext{
${ }^{3}$ See Naik, Reflections on The Future of Development of Education in India (Paris: UNESCO,1980) pp. 61-64.
} 
Naik emphasizes that,

Education is a double-edged sword; while wrong education could lead to social disintegration, the right kind of education can bring about effective national development. The most effective way of breaking the vicious circle in which we find ourselves at present is to begin an educational reconstruction in a big way. That is why the commission placed the highest emphasis on creation of a national system of education through an educational revolution... If we desire to get out of this vicious circle, create an egalitarian society and an egalitarian education system, we must mount a big offensive on both social and educational fronts. ${ }^{4}$

The commission had correctly identified the elitist character of our society. The two main forces of modernization, education and science and technology, have helped the elite to improve their standards of living but have not done a corresponding service to the masses of the people. The commission recommended adoption of a new philosophy: faith in the common man. Four decades later, India has taken a decisive step to soften the sharp edges of the dualistic system of elementary education. Cheating the poor with poor quality education can be phased out rather quickly, if the government delivers on its promise and NGO's create enough pressure and hold the governments to account (Bhatt, 2005). The poor must be made aware of their newly acquired Right to Education and entitlement to vote. Meeting the MDG No 2 by 2015 is within striking distance provided the state governments in UP, Bihar, MP, Maharashtra, Orissa and Rajasthan implement the law earnestly. Required resources and delivery effort would be a major challenge.

\section{Child Poverty, Compulsory Education Law and Unique Identification}

Unique Identification Authority of India (UIDAI) established in 2009 is located within the Planning Commission of India. The concept originated with the Planning Commission in 2006 for use primarily as the basis for efficient delivery of welfare services. It was also expected to act as a tool for effective monitoring of various programs and schemes of the government. The Unique Identification (UID) has made major strides during the last 18 months. UIDs have been distributed in some parts of India and the programme has been accelerating its delivery. Issues of child poverty require targeted delivery of a number of services to households living below the poverty line. UID can be used to track implementation of compulsory elementary education Law of 2010 for children living in

\footnotetext{
${ }^{4}$ See Naik (1980), ibid, pp. 67
} 
poverty. We have shown that some major states like UP, Bihar, Maharashtra and MP account for half of total child population and a much larger share of children living in poverty and not participating in school education. Distribution of the foundational requirements of unique ID called 'Aadhaar', can be given priority in these States and regions and also to families accessing various poverty reduction programs. This would enable the policymakers to achieve efficient delivery of services and also at lower costs. Later on, monitoring and evaluation would get more focused on the groups that were supposed to benefit from these programs. In elementary education we are unable to precisely track the student cohorts from grade 1 to completion of primary stage at grade 5 or from grade 6 to completion of upper primary stage at grade 8 . It will be possible to undertake meaningful evaluations with the use of unique IDs. A backward district in each of these major states can be given priority for the issue of these unique IDs as a priority. This will provide additional, accurate information to the Child's Rights Commission with a potential for meaningful debates on child poverty reduction and implementation of the Education Law of 2010.

\section{Conclusions}

This paper has investigated a number of issues related to the status of children and demographic transition of various Indian states across time using NSS household data for 2004-05 \& 1993-94 and Census data for the period 1961-2001 and their implications for compulsory Education law. TFR have declined in all states of India between 1961 and 2001. However, for states such as Tamil Nadu, Karnataka, Kerala, Andhra Pradesh, West Bengal and Himachal Pradesh the decline has been quite dramatic with TFR falling to near or below 2 in 2001, implying declining child population. Hence, these states are in a virtuous spiral with rising (living) standards leading to lower TFR which then feeds into rising living standards. Some other states, e.g., Bihar, UP, Haryana, Jharkhand, Chattisgarh, Rajasthan, Punjab, Orissa and Maharashtra have TFR much above 2 and, hence, have growing populations (vicious spiral). The All-India TFR is above 2.1 whence the population of the country as a whole is growing. Thus, we find that there is decline in absolute number of children in some states but increase in others. The principal reason for the decline in TFR is the decline in the Infant Mortality Rate and increase in girls' education. A focus on girls' education is still needed, particularly in states in the vicious spiral.

The average number of children for ultra poor, poor, non-poor low and and non-poor high are respectively 4.4, 5.7, 4.9 and 3.9. Using a t-test the differences in the number of chidren 
across these categories in all pairwise comparisons are significant at 1 per cent. Children living in poorer households are larger proportion of child population than proportion of poor in total population. Hence, using the Compulsory Education Law to focus on this subgroup as a priority will have high social benefits.

In the population as a whole while $82 \%$ of children aged 5-14 are in school only $71 \%$ of children in ultra-poor households and $72 \%$ in poor households are in schools. The proportions for children in non-poor low and non-poor high households are much higher ( $85 \%$ and $95 \%$ respectively). Hence, in a Business as Ususal scenario a greater proportion of children from poor households will face a life without education and hence, possibly, poverty than children from non-poor households. The incidence of child labor and of children being 'nowhere' is much higher among poor hosueholds than among non-poor households. From the vantage point of the Compulsory Education Law these children will need bridging courses before they can be absorbed into the regular education stream. We have not examined educational quality or school related supply side factors.

Analysis at the level of individual states reveals that by an large, states in the virtuous spiral have higher school attendance and lower incidence of child labor and children in the 'nowhere' category as compared to states in the vicious cycle. A bi-modal distriution of states is unmistakable. A policy implication is that focusing on states in the vicious spiral will require a big push in financial inputs, restructuring of institutions and enhanced monitoring. Finally, the paper investigates the determinants of non-attendance in schools for children aged 5-14 using two models: a probit model for non-attendance in schools and a multinomial logit model of children being in the labor force and 'nowhere'. The higher the number of children in the household and the greater the proportion of girls among the children the gereater the likelihood of a child not being in school. Children from houehsolds with higher per capita expenditures are less likely to be out of school. Children from female headed households have a lower risk of not being in school. The dependence of non-attedance on varoius social factors such as caste and state dummies is also investigated as are varoius interaction effects.

The estimated multinomial logit model also yields several insights - in particular that, ceteris paribus, girls who are not in school are more likley to be 'nowhere' than in the labor force as compared to boys. Socio-cultural identifiers, ST, SC, Muslims and also gender, turnout to be relevent in our formal econometric estimates for both periods. Interactions with expenditure 
on education and health in these groups also showed expected relationships. Child labour among Muslims and SC continue to be a cause for concern but not among ST. On a positive note, the change between 1993-94 and 2004-05 is in the right direction.

Our analysis found impressive improvements in school enrolements between 1993-94 and 2004-05. Incidence of child poverty also declined for India as a whole with mixed but generally positive results from states. Rise in urban child poverty in states like Maharashtra needs attention. Similarly, increase in child labour and nowhere children in some states like Rajasthan, Maharashtra and even in Delhi should be a cause for serious concern. Overall, implementation of Compulsory Education Law in the coming years requires immediate and serious attention to the underlying causes of child poverty and its re-enforcing factors discussed above. Resurgent India with one in three children living in absolute povert would be a pipe dream. Opportunity for reaping demographic dividends would be lost.We cannot undo the past but future is ours to make.

\section{References}

Bhatt, A. (2005), Supreme Court on Children, Delhi: Human Rights Law Network.

Caldwell, J.C. (1990), 'The Soft Underbelly of Development: Demographic Transition in Conditions of Limited Economic Change', in Proceedings of the World Bank Annual Conference on Development Economics, World Bank, Washington D.C.

Caldwell, J.C. (1998), 'Malthus and the Less Developed World: The Pivotal Role of India', Population and Development Review, 24(4), pp. 675-696.

Chaudhri, D.P. (1996), A Dynamic Profile of Child Labour in India New Delhi: International Labour Office.

Chaudhri, D.P. (1997), 'A Policy Perspective on Child Labour in India with Pervasive Gender and Urban Bias in School Education', The Indian Journal of Labour Economics, 40(4), (OctDec), p.789-808.

Chaudhri, D.P. (2000), 'Basic Human Rights, Core Labour Standards and Relative Educational Deprivation of Youth in Modern Indian States', V.V. Giri Memorial Lecture, reproduced in The Indian Journal of Labour Economics, 43(1), Jan-March, 2000.

Chaudhri, D.P. (2010), 'Child's Rights and Elementary Education in India', Prabuddha Bharata, 115(12), pp. 669-75.

Chaudhri, D.P. and C. Nyland (2002), 'Globalisation, Demographic Pressures and Child Labour Standards', The Indian Journal of Labour Economics, 4(3) (Jul-Sep), pp. 537-560.

Chaudhri, D.P. and E. Wilson (2002),'Nutritional Poverty, School Education and Supply of Child Labour', in Nira Ramachandran and Lionel Massum (eds) Coming to Grips with Rural Child Work, Delhi: Institute of Human Development \& United Nations World Food Programme.

Chudgar, Amita, (2010), 'Female Headship and Schooling Outcomes in Rural India', World Development (forthcoming) 
Dreze, J. and A. Sen (1995), Economic Development and Social Opportunity, Delhi: Oxford University Press.

Dreze, J. and A. Sen (1997), Indian Development, Delhi: Oxford University Press.

Education Commission Report (1966), Education and National Development: Report of the Education Commission, New Delhi: Ministry of Education, Government of India.

Government of India, (2009), The Rights of Children to Free and Compulsory Education Act 2009, The Gazette of India, No 39, Ministry of Law and Justice, New Delhi.

Govinda, R. (2008), Access to Elementary Education in India: Country Analytical Review, New Delhi: National University of Educational Planning and Administration.

Himanshu (2007), 'Recent Trends in Poverty and Inequality: Some preliminary results', Economic and Political Weekly, 42(6), 497-508, 10 February.

Mehrotra, Santosh (ed.) (2006), The Economics of Elementary Education in India, Sage, New Delhi.

MHRD (2009), Website: http://www.education.nic.in/ for details on the 2009 Act.

Naik, J.P. (1975), Elementary Education in India: A Promise to Keep, Delhi, Allied Publishers. .

Naik, J.P. (1980), Reflections on The Future of Development of Education in India, Paris: UNESCO.

Naik, J.P., K.G. Saiyidain and S. Abid Hussain (1952), Compulsory Education in India Paris: UNESCO.

National Sample Survey (2011) Details of National Sample Survey data available at http://mospi.nic.in/nsso_4aug2008/web/nsso.htm

NUEPA on Education Data http://www.education.nic.in/ and also http://www.dise.in/ for recent details.

Oxford University (2010), The Oxford Poverty and Human Development Initiative, see website: http://www.ophi.org.uk/policy/multidimensional-poverty-index/

Planning Commission (2009), 'Expert Committee Report on Poverty Measurement', Planning Commission of India, New Delhi.

Probe Team (1999), Probe Report on Elementary Education, Oxford University Press, New Delhi

PROBE II, A. Shiva Kumar et al. (2010) Education for all is the policy, but what is the reality? (Chennai: Frontline, 26(6). Probe II in Press (2011).

Ray, Ranjan 1999), 'Household Size and Child Welfare in India', working paper, School of Economics, University of Tasmania, Australia.

Rustagi, Preet and Raj. G. Mitra (2008), 'South Asia Regional Child Poverty Network', PPP at 7-9 May 2008 meeting sponsored by UNICEF, New Delhi.

Rustagi, Preet (ed.) (2009), Universalisation of Elementary Education in India: Concerns, Conflicts and Cohesions, Oxford University Press, New Delhi

Registrar General of India (2006), Expert Committee Report on Population Projections till 2026, New Delhi: Registrar General's Office.

Tilak, J.B.G. (1996) 'How Free is Primary Education in India' (Parts I and II), Economic and Political Weekly, 31(5 and 6): pp. 275-82 and 355-66.

UIDAI (2011), 'Unique Identification Authority of India and AADHAAR', Government of India, New Delhi

UNDP (2010), Human Development Report 2010, UNDP, New York.

Weiner, M. (1991), The Child and The State in India, Princeton: Princeton University Press.

Wooldridge, J.M. (2006), Introductory Econometrics, Mason, $3^{\text {rd }}$ edn, OH: Thomson: South Western. 
Figure 1: Child Population (5-14 years) in Indian States 1961-2005 with Projections to 2026

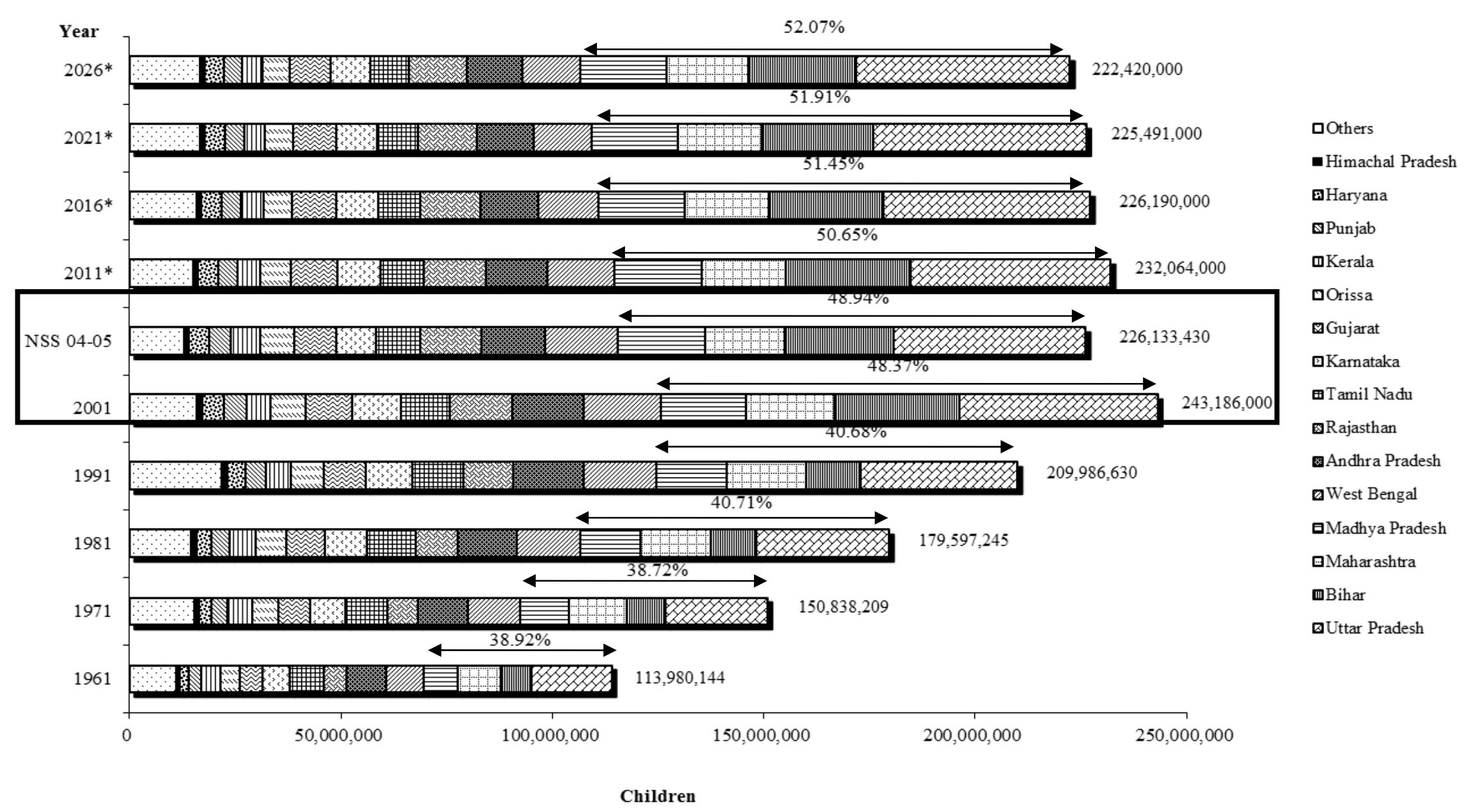

Sources: 1. Census of India 1961, 1971, 1981, 1991, 2001, NSS 61 ${ }^{\text {st }}$ Round for 2005, and Population Projections for India and States 2001-2026 (Census of India 2001). 2. Chaudhri \& Jha, 'Child Poverty and Elementary Education in India', ASARC Working Paper 2011/04. 
Figure 2: Total fertility rates in major states of India 1961-2001

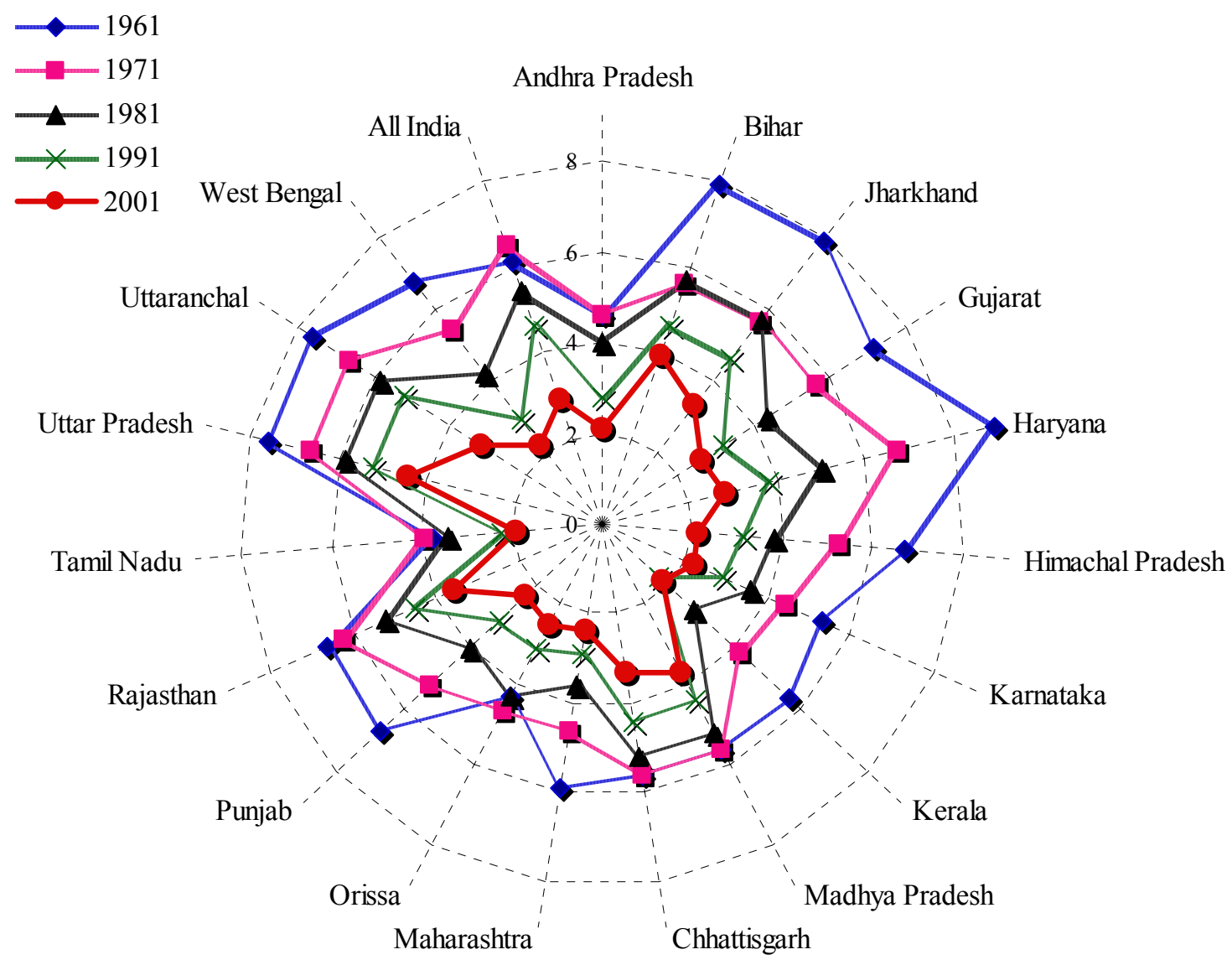

Sources: 1. Census of India 1961, 1971, 1981, 1991 and 2001

2. Ron C. Mittelhammer, Tauhidur Rahman (2004), Distribution of Human Development, Child Labor and Poverty in India.

3. National Commission on Population MHFW 2006

4. Chaudhri \& Jha, 'Child Poverty and Elementary Education in India', ASARC Working Paper 2011/04. 
Figure 3: Household size, number of children (0-14) in poor and non poor households in India 2004-05
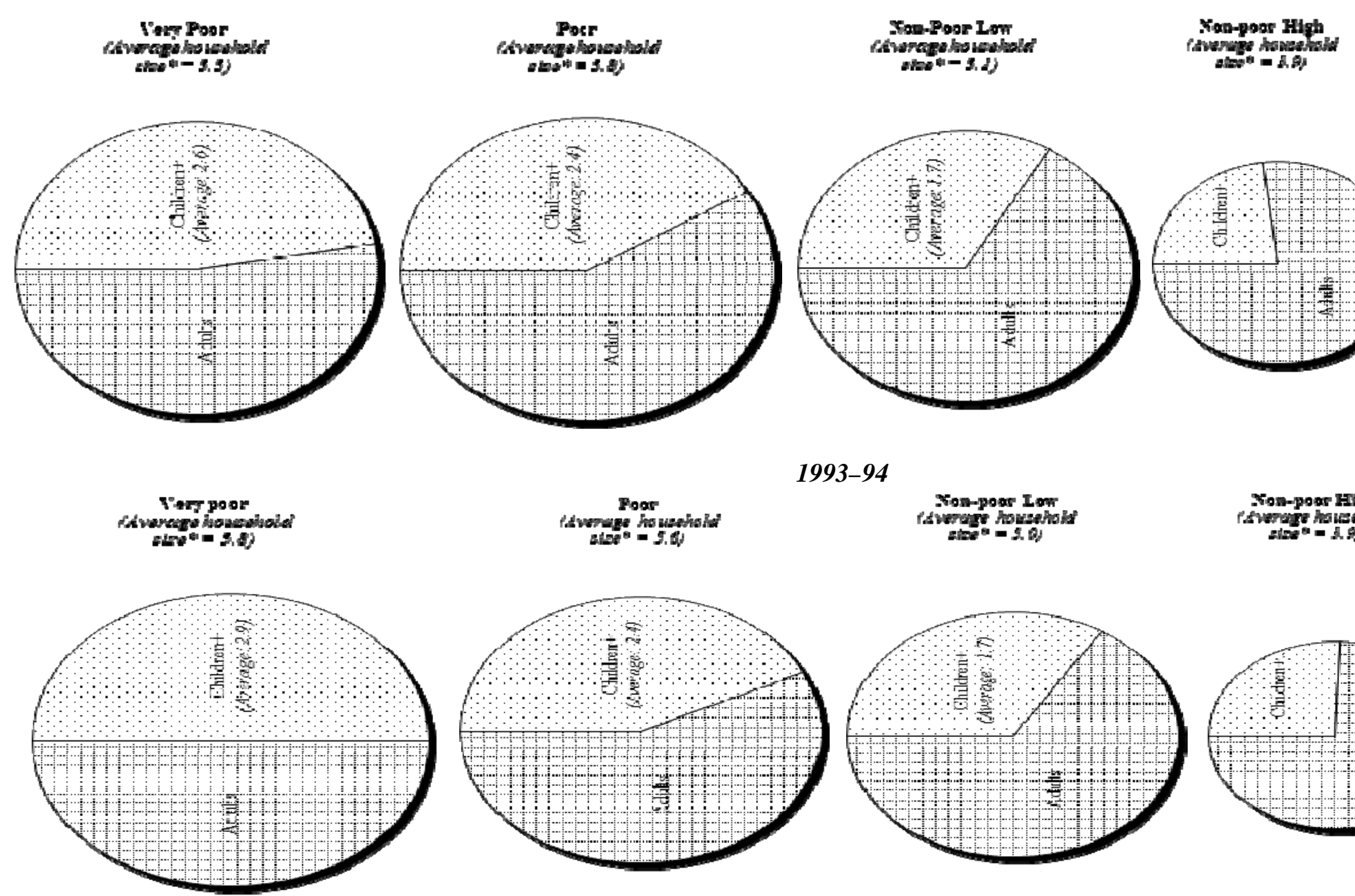

1993-94
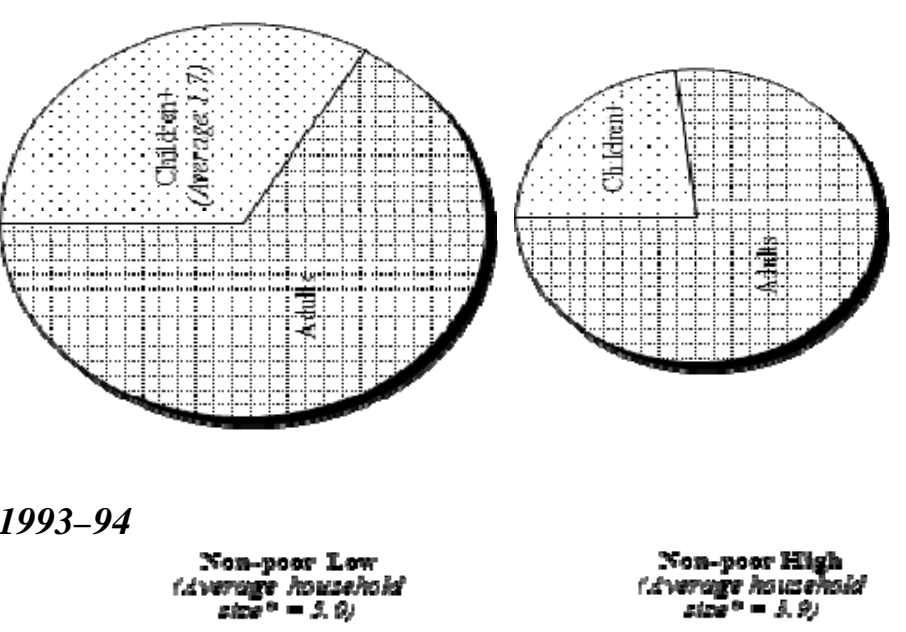

Sources: 1. Computed from NSS 61st Round for 2004-05 and NSS 50th Round for 1993-94

2. 'Poverty estimates for 2004-05', Press Information Bureau of Government of India, New Delhi, March-2007

3. Savita Sarma, 'Poverty Estimates in India: Some key issues', ERD Working Paper Series No. 51, ADB, May 2004

4. Chaudhri \& Jha, 'Child Poverty and Elementary Education in India', ASARC Working Paper 2011/04.

Notes: * all pairwise comparisons of differences in mean values of household size are statistically significant at $1 \%$ within the two samples and also between $1993-94$ and $2004-05$

+ all pairwise comparisons of differences in mean values of number of children are statistically significant at $1 \%$ within the two samples and also between $1993-94$ and $2004-05$ 


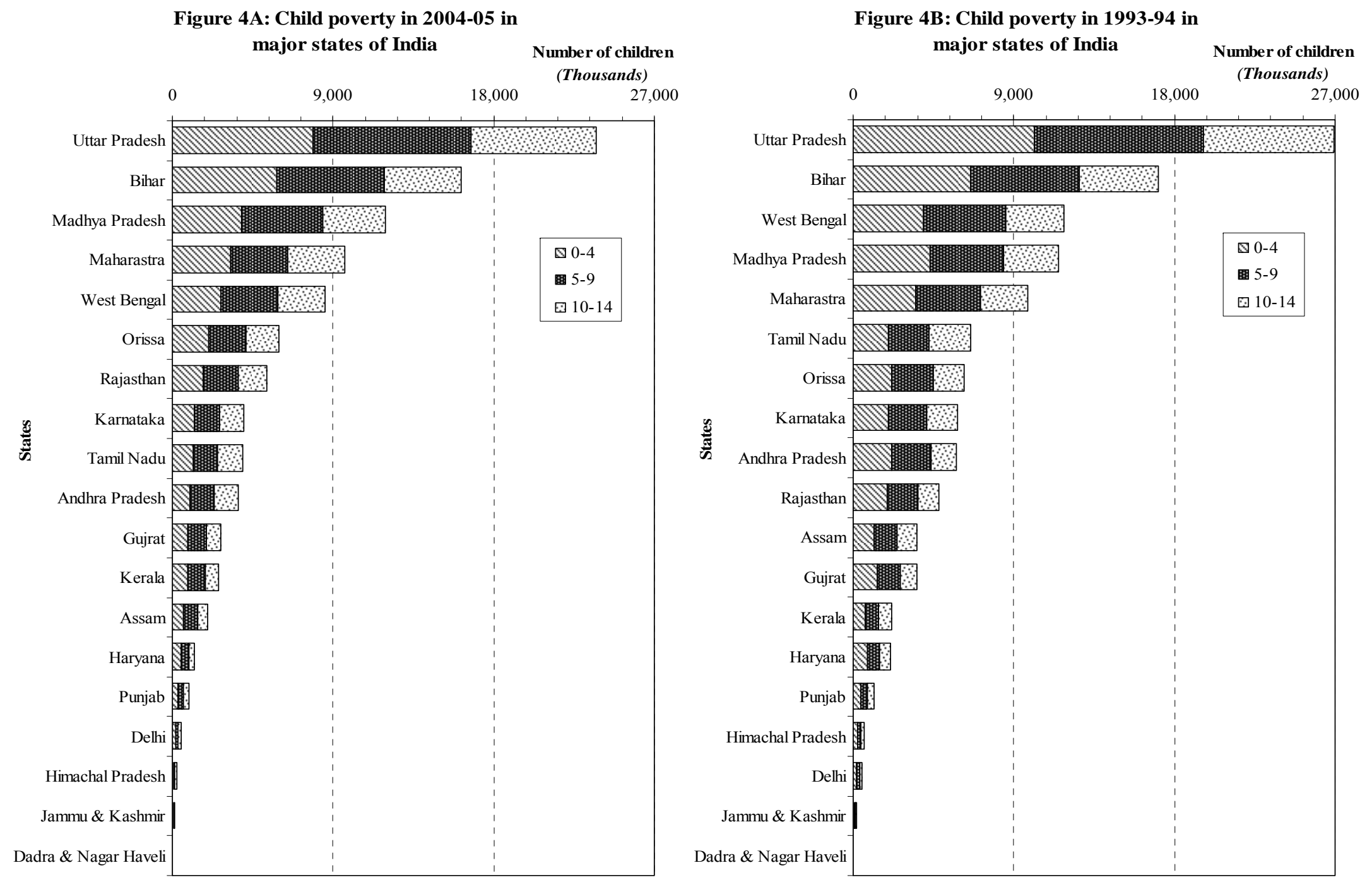

Sources: 1. Computed from NSS 61st Round for 2004-05 and NSS 50th Round for 1993-94

2. Chaudhri \& Jha, 'Child Poverty and Elementary Education in India', ASARC Working Paper 2011/04. 

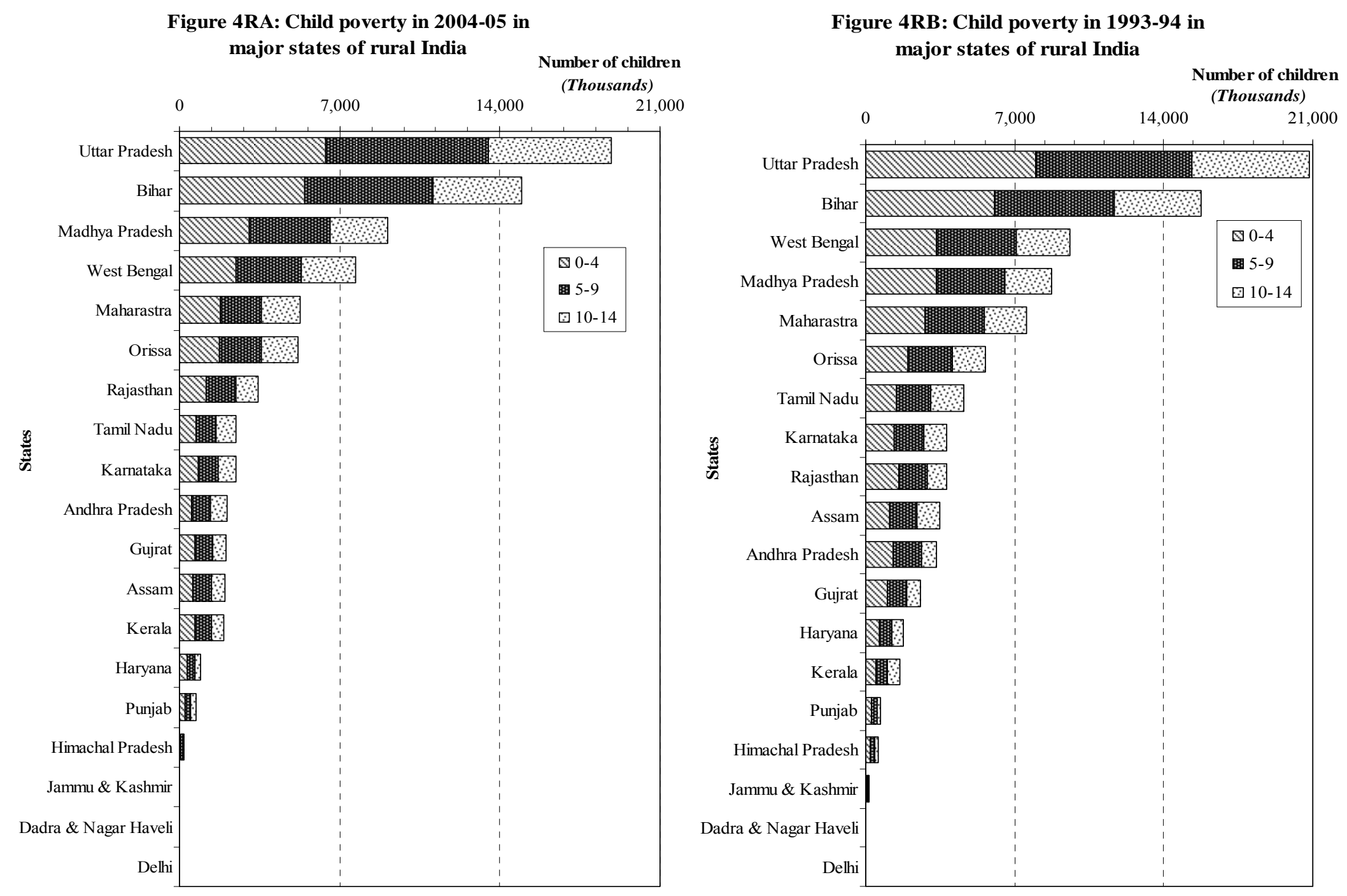

Sources: 1. Computed from NSS 61st Round for 2004-05 and NSS 50th Round for 1993-94

2. Chaudhri \& Jha, 'Child Poverty and Elementary Education in India', ASARC Working Paper 2011/04. 


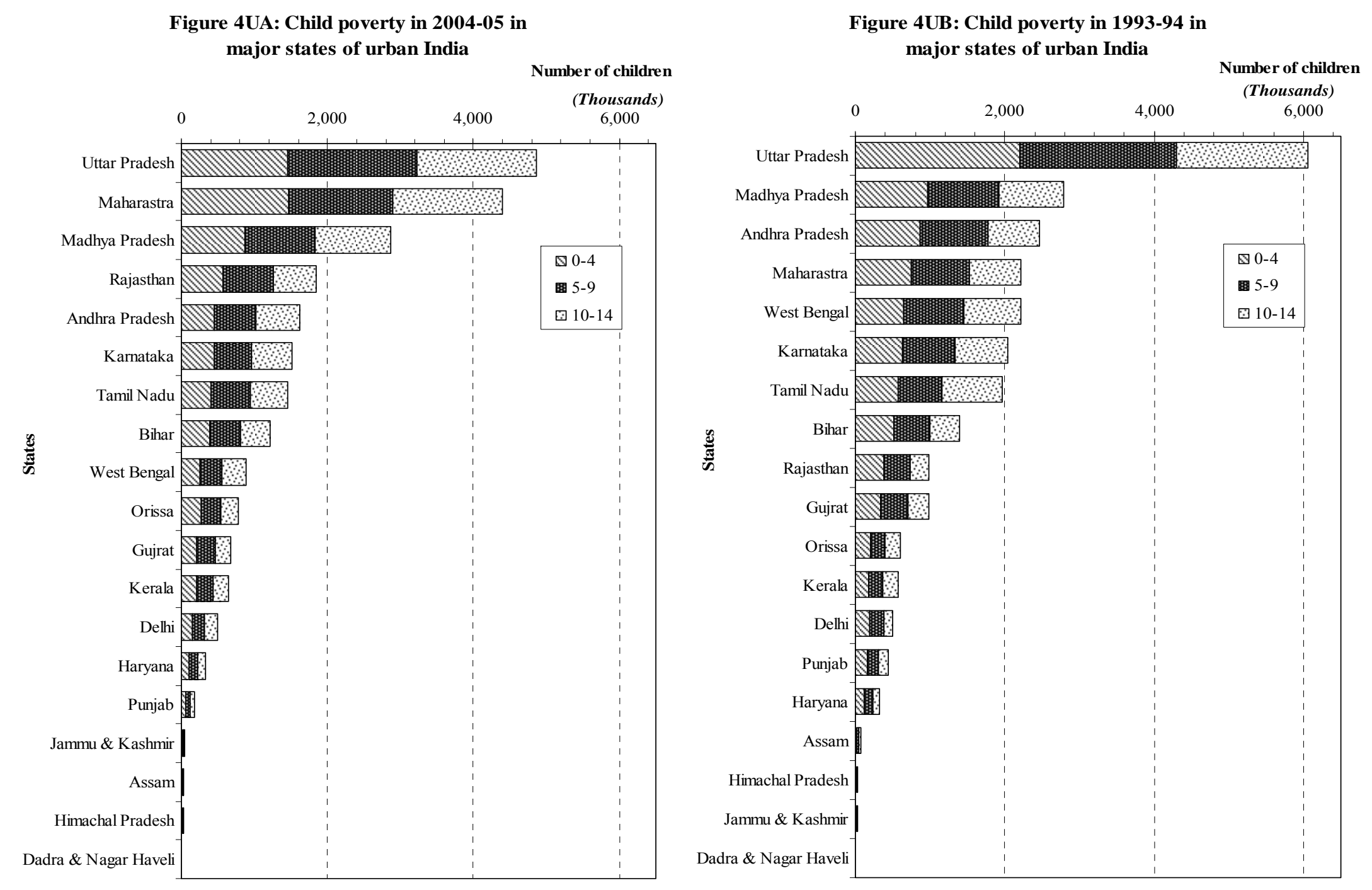

Sources: 1. Computed from NSS 61st Round for 2004-05 and NSS 50th Round for 1993-94

2. Chaudhri \& Jha, 'Child Poverty and Elementary Education in India', ASARC Working Paper 2011/04 


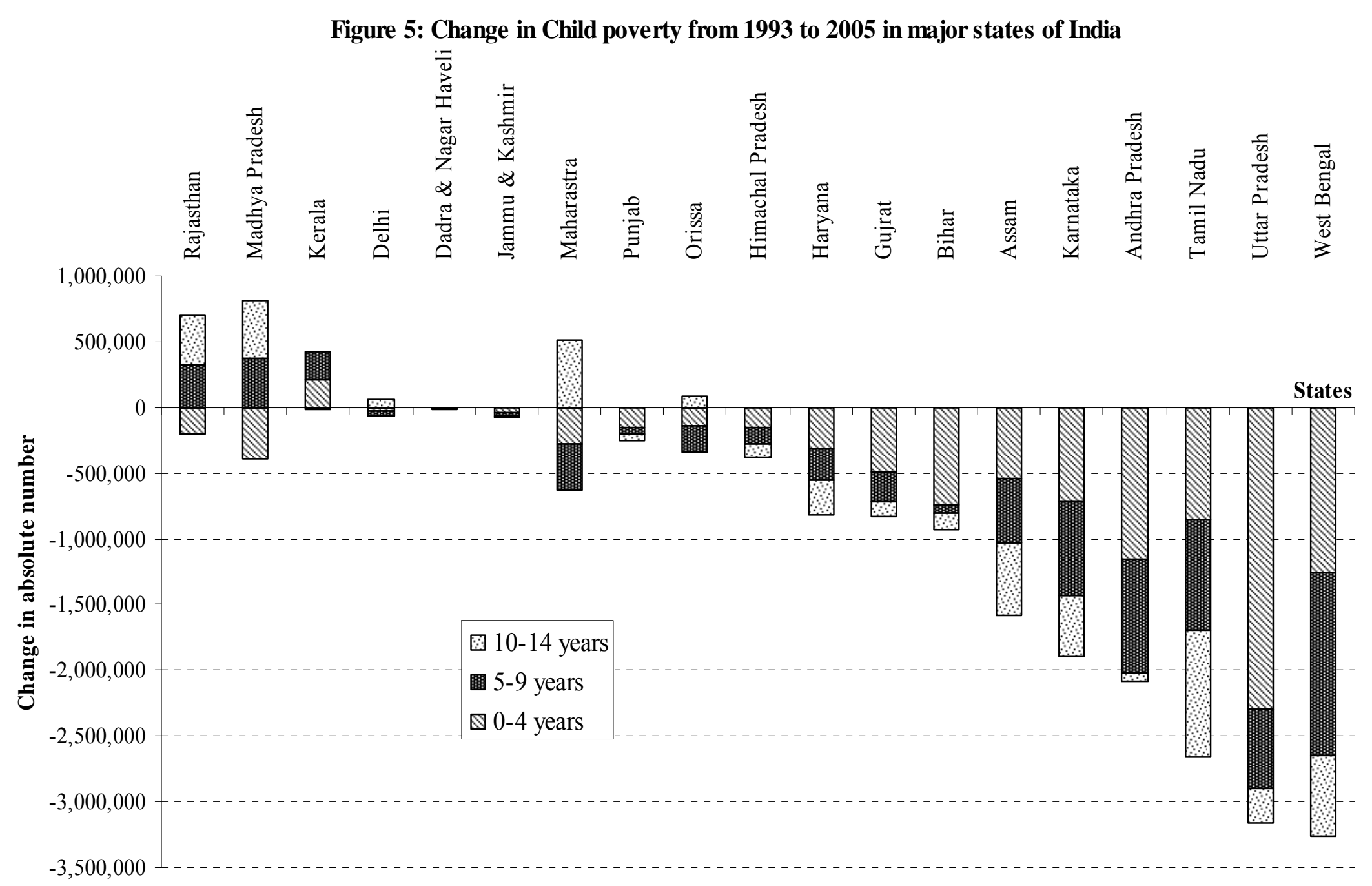

Sources: 1. Computed from NSS 61st Round for 2004-05 and NSS 50th Round for 1993-94

2. Chaudhri \& Jha, 'Child Poverty and Elementary Education in India', ASARC Working Paper 2011/04. 
Figure 5R: Change in Child poverty from 1993 to 2005 in major states of Rural India

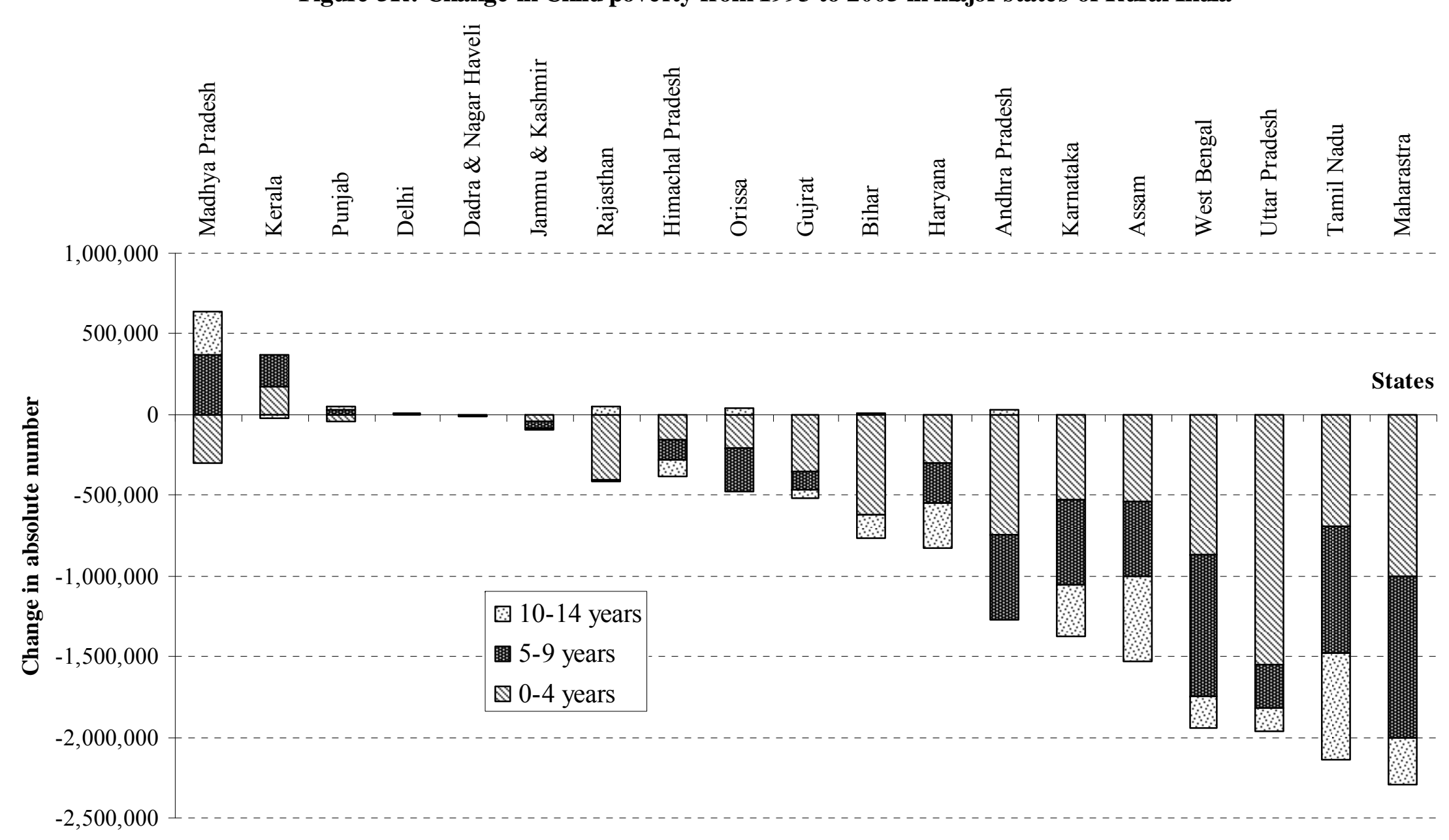

Sources: 1. Computed from NSS 61st Round for 2004-05 and NSS 50th Round for 1993-94

2. Chaudhri \& Jha, 'Child Poverty and Elementary Education in India', ASARC Working Paper 2011/04. 
Figure 5U: Change in Child poverty from 1993 to 2005 in major states of Urban India

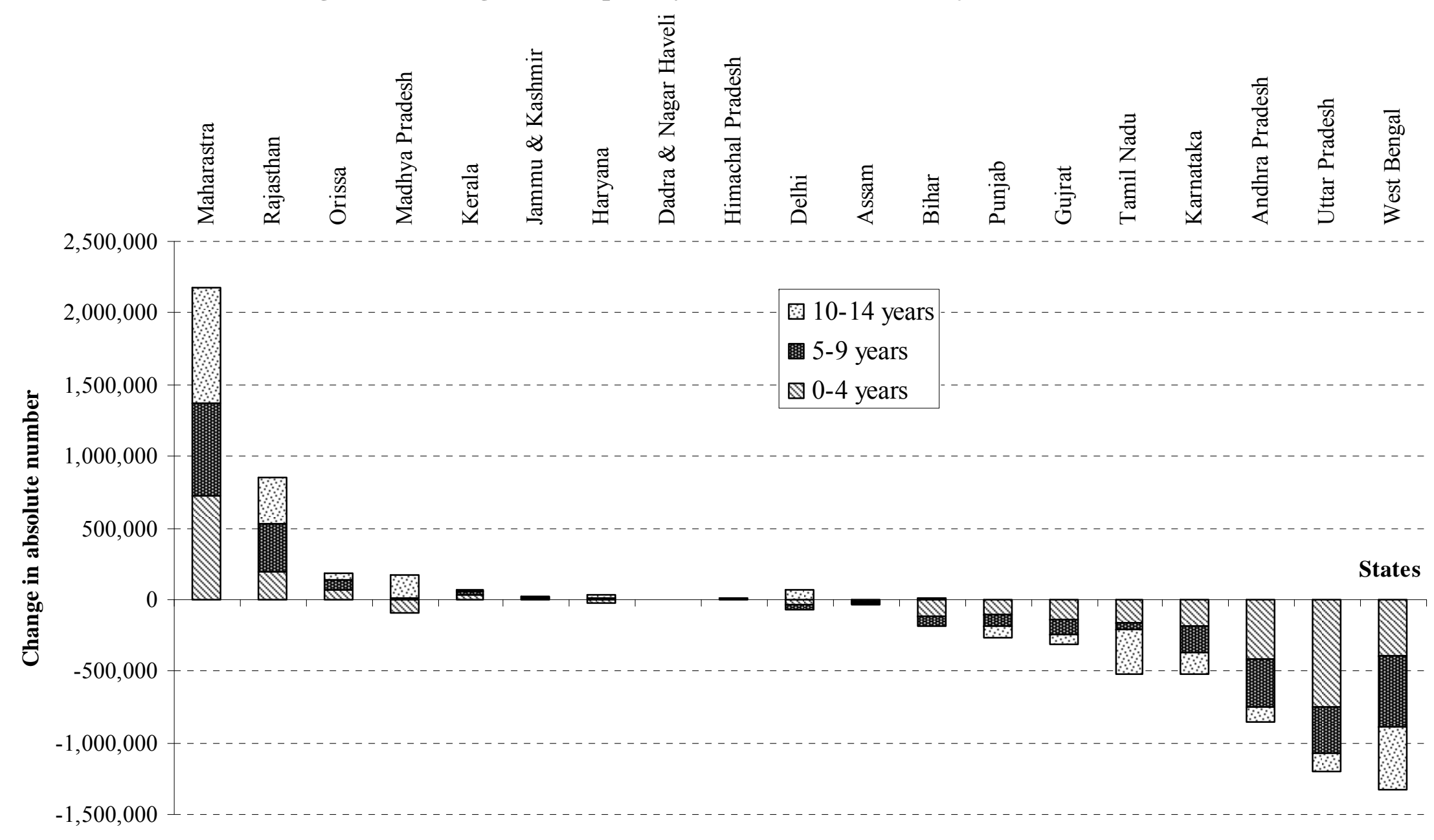

Sources: 1. Computed from NSS 61st Round for 2004-05 and NSS 50th Round for 1993-94

2. Chaudhri \& Jha, 'Child Poverty and Elementary Education in India', ASARC Working Paper 2011/04. 
Figure 6: Child population (5-14) in schools, in labour force and nowhere by poverty status in India

\section{axacroces

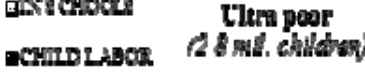

ancoratere
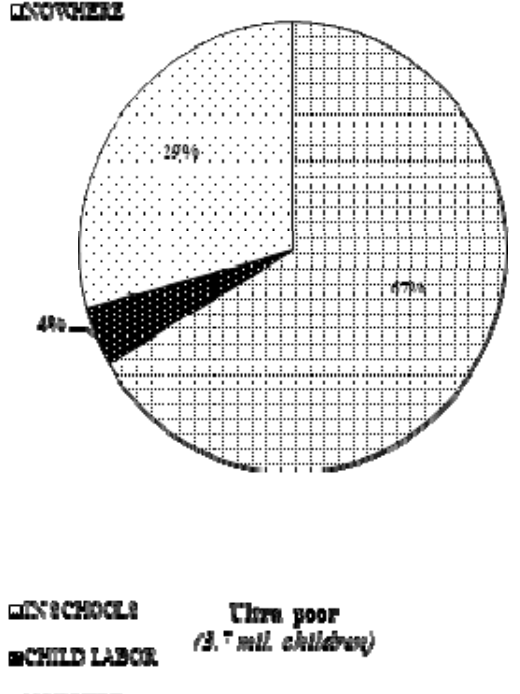

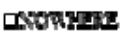

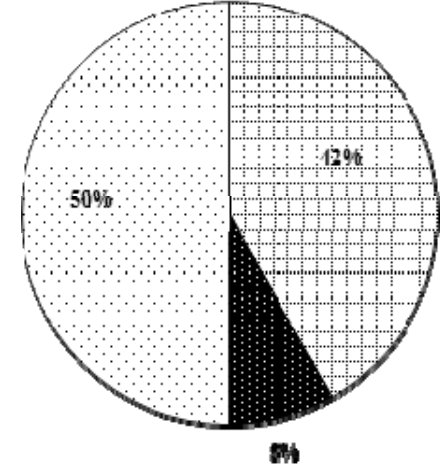

2004-05

Xom
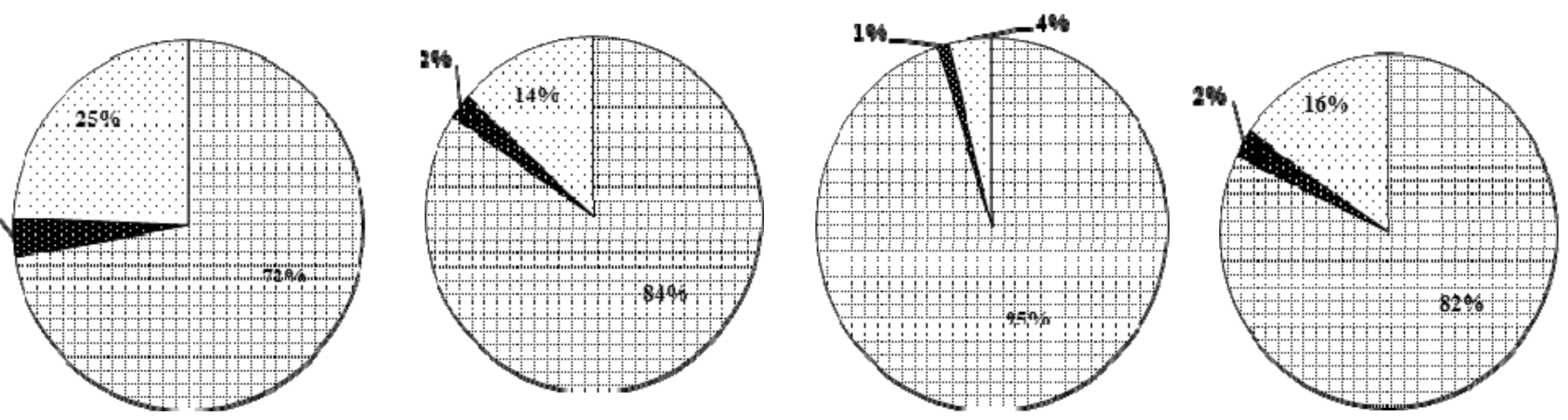

1993-94

$$
\text { Poor }
$$

162.8 Alll. ehthowi

Ti.s

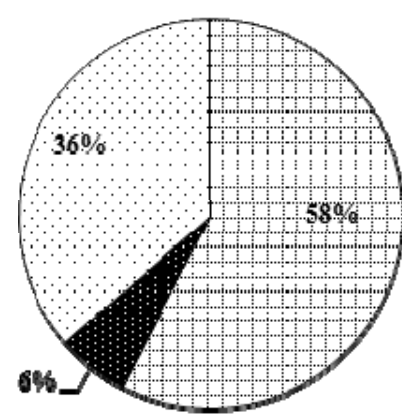

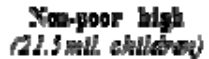

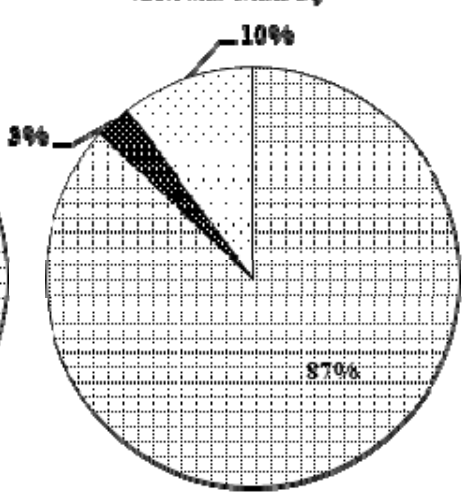

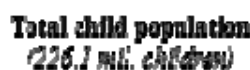

Sources: 1. Computed from NSS 61st Round for 2004-05 and NSS 50th Round for 1993-94

2. Chaudhri \& Jha, 'Child Poverty and Elementary Education in India', ASARC Working Paper 2011/04. 
Figure 7P: Children in poverty (5-14 years) in schools, labour force and non-participation in major states of India 2004-05

\section{Number of children}

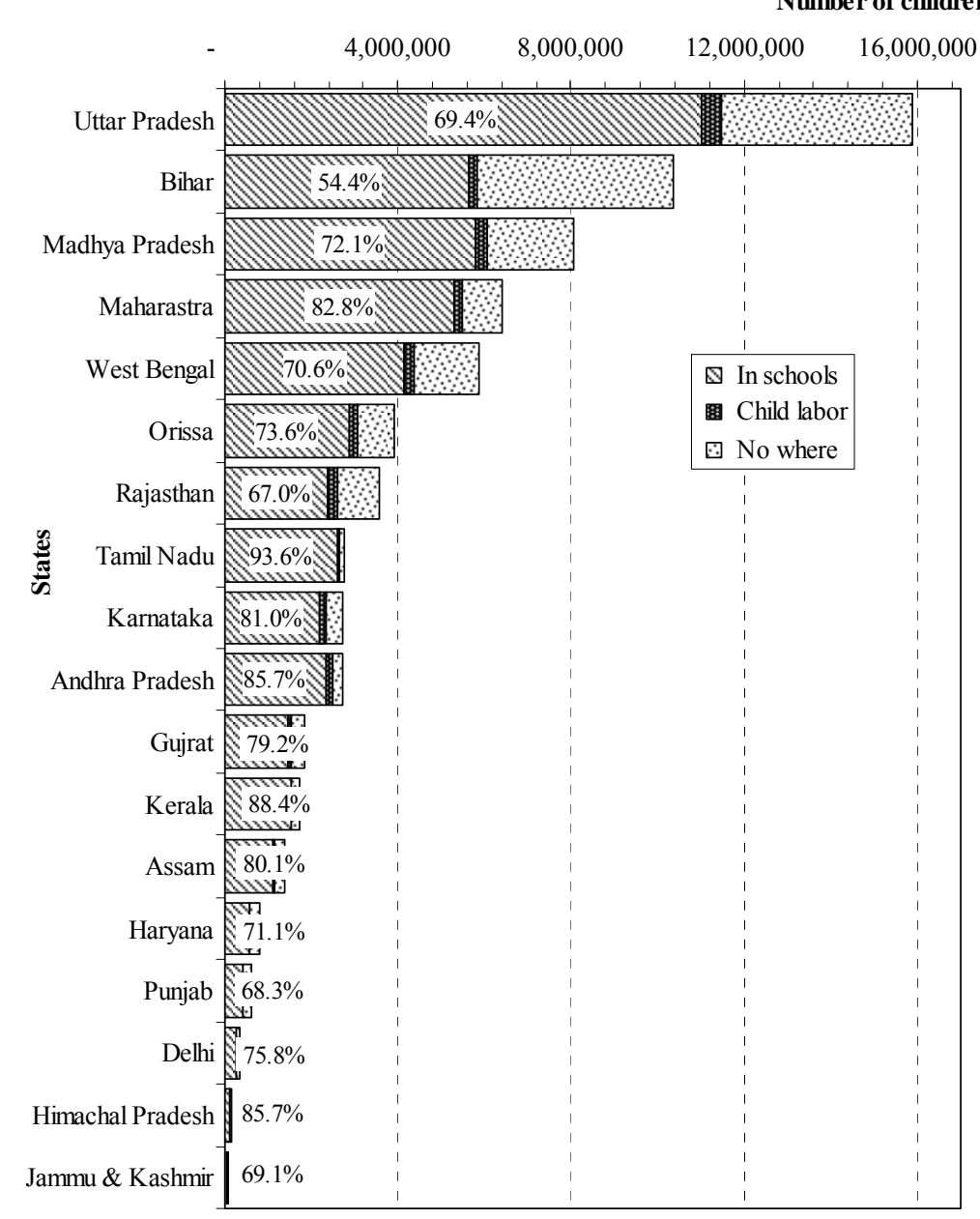

Figure 7NP: Non-poor children (5-14 years) in schools, labour force and non-participation in major states of India 2004-05

Number of children

Madha Pradesh
Maharastra

Sources: 1. Computed from NSS 61st Round for 2004-05 and NSS 50th Round for 1993-94

2. Chaudhri \& Jha, 'Child Poverty and Elementary Education in India', ASARC Working Paper 2011/04. 
Figure 7RP: Children in poverty (5-14 years) in schools, labour force and non-participation in major states of Rural India 2004-05

Number of children

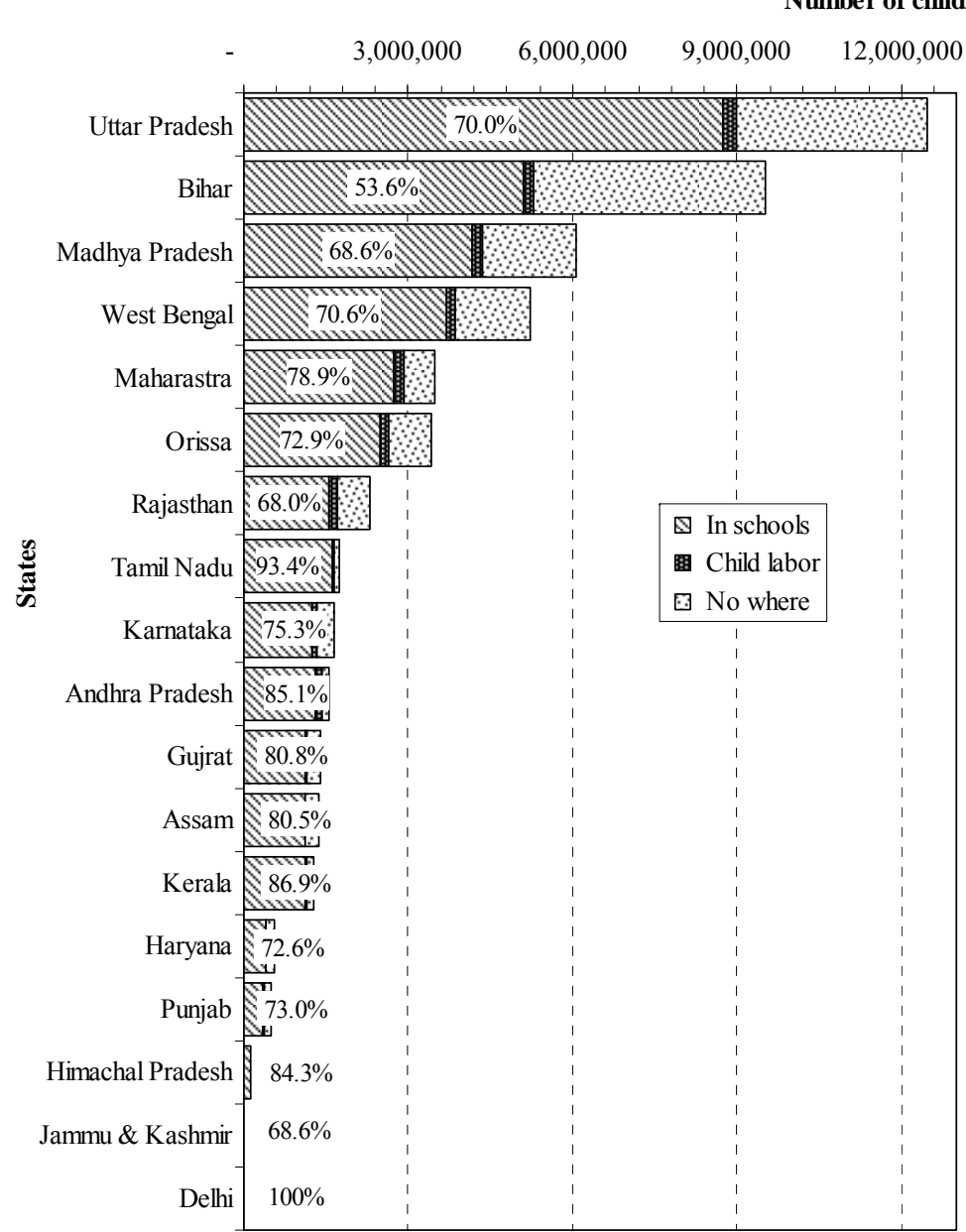

Figure 7RNP: Non-poor children (5-14 years) in schools, labour force

and non-participation in major states of Rural India 2004-05

Number of children

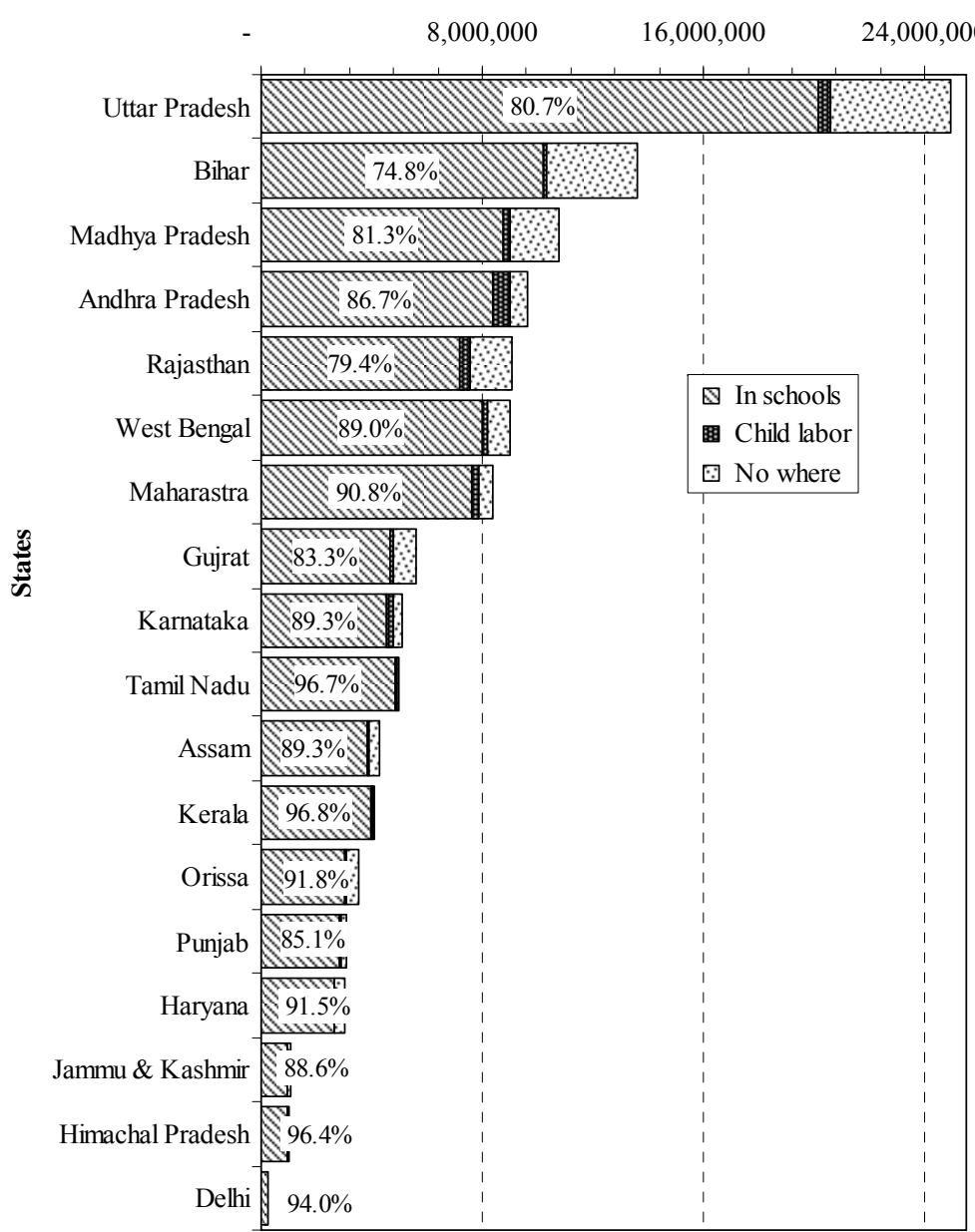

Sources: 1. Computed from NSS 61st Round for 2004-05 and NSS 50th Round for 1993-94

2. Chaudhri \& Jha, 'Child Poverty and Elementary Education in India', ASARC Working Paper 2011/04. 
Figure 7UP: Children in poverty (5-14 years) in schools, labour force and non-participation in major states of Urban India 2004-05

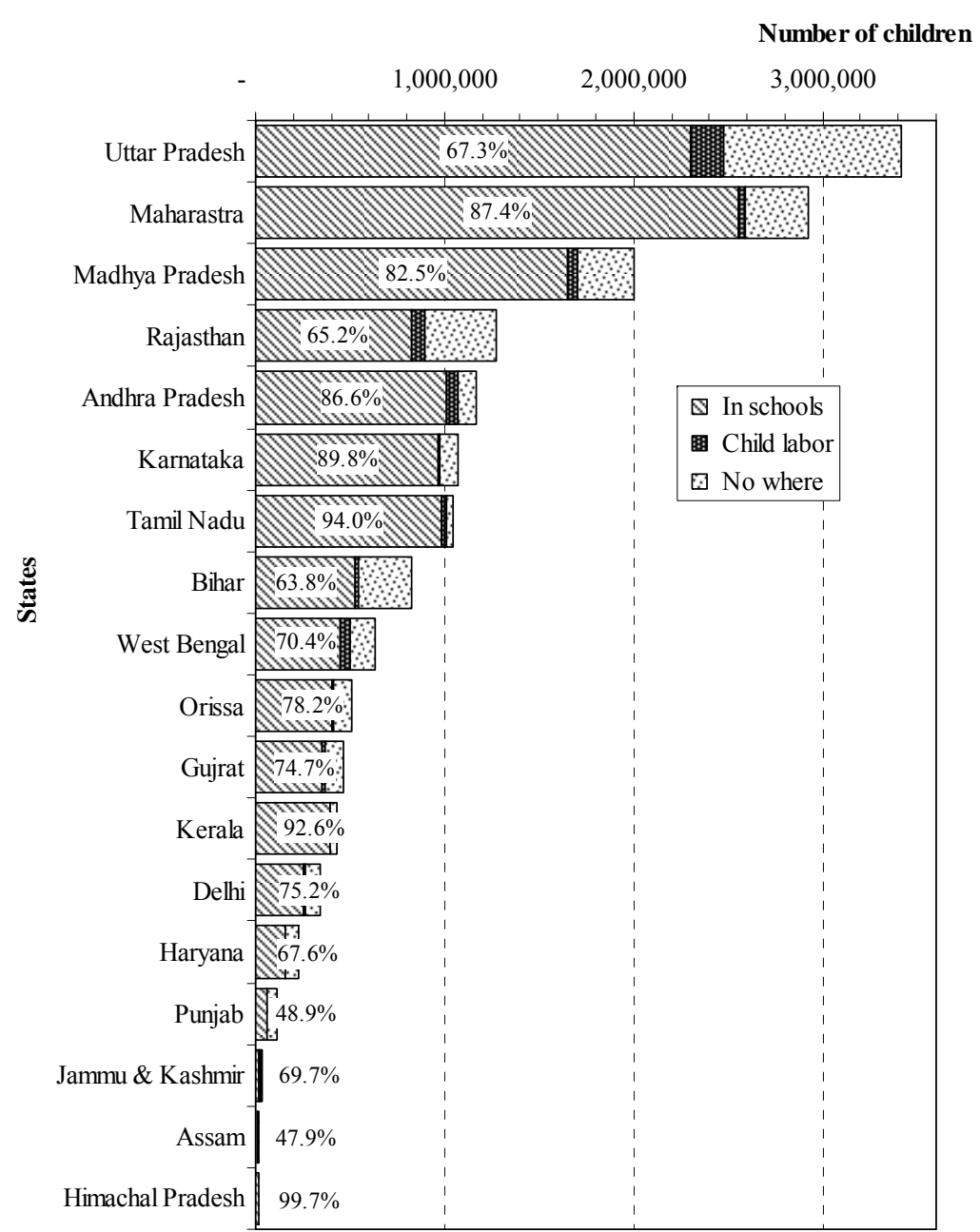

Figure 7UNP: Non-poor children (5-14 years) in schools, labour force and non-participation in major states of Urban India 2004-05

Number of children

$4,000,000$

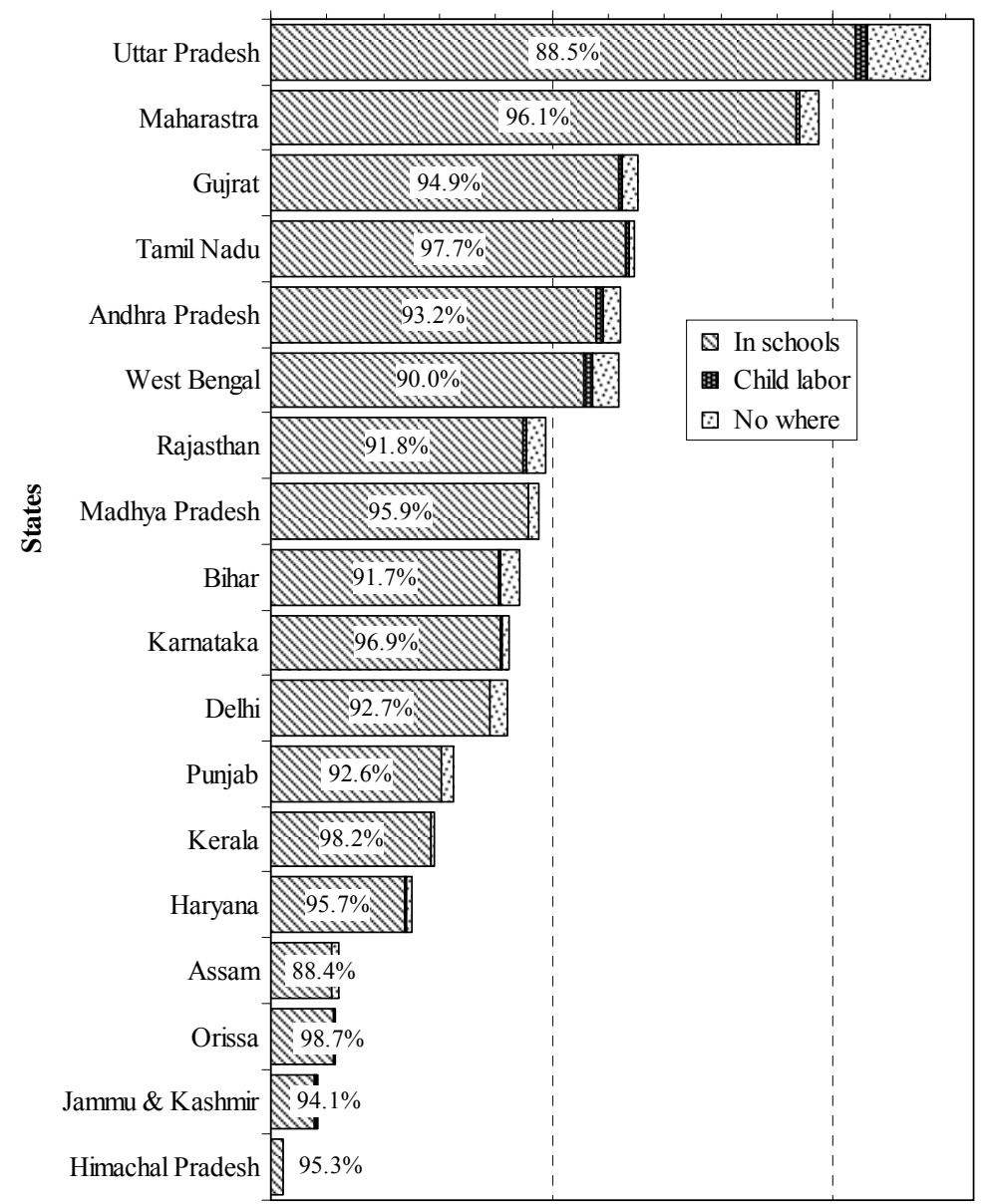

Sources: 1. Computed from NSS 61st Round for 2004-05 and NSS 50th Round for 1993-94

2. Chaudhri \& Jha, 'Child Poverty and Elementary Education in India', ASARC Working Paper 2011/04. 
Figure 8: Change in children's participation in schooling, child labour and non-participation from 1993-94

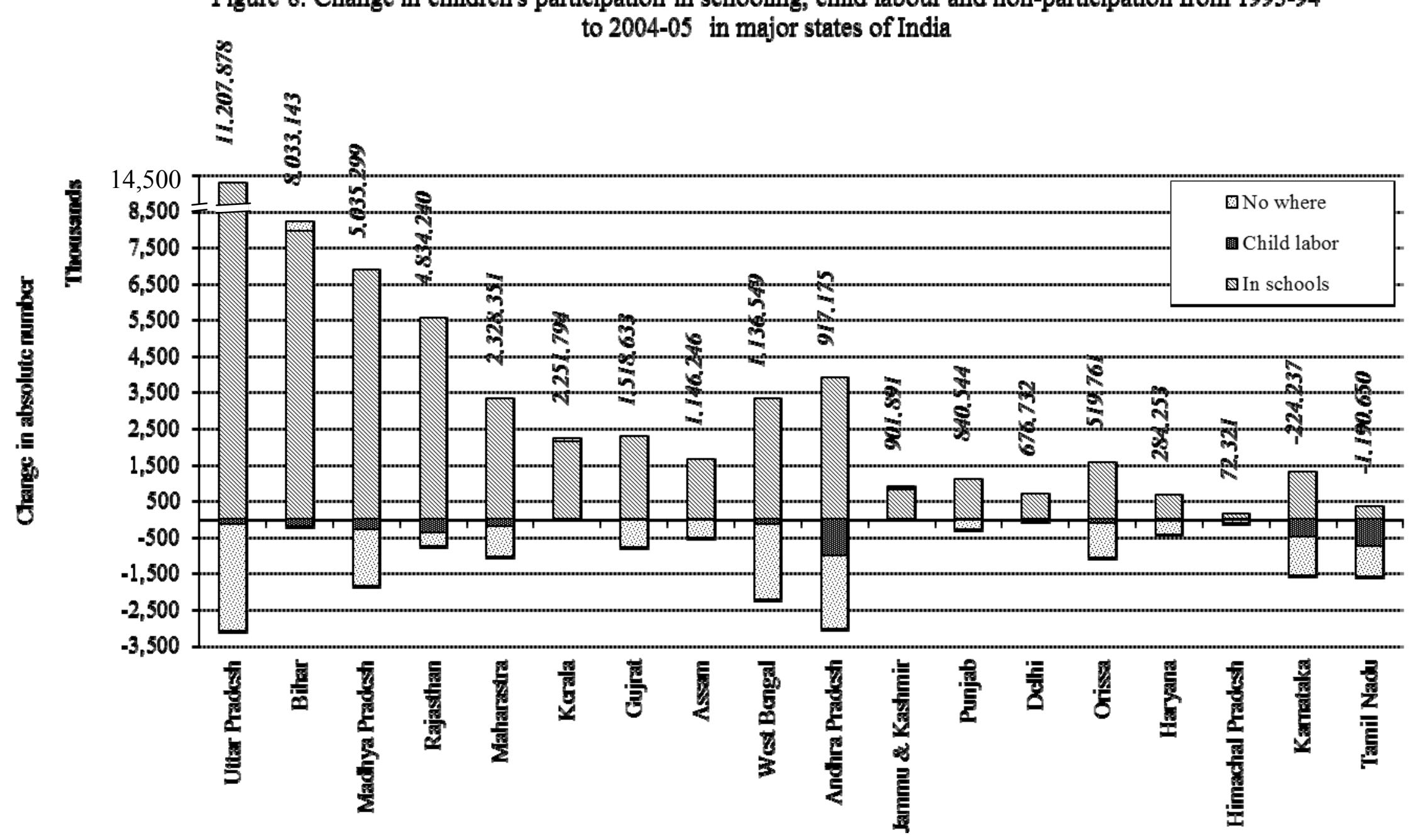

Sources: 1. Computed from NSS 61st Round for 2004-05 and NSS 50th Round for 1993-94

2. Chaudhri \& Jha, 'Child Poverty and Elementary Education in India', ASARC Working Paper 2011/04. 
Figure 8R: Change in children's participation in schooling, child labour and non-participation from 199394 to 2004-05 in major states of rural India

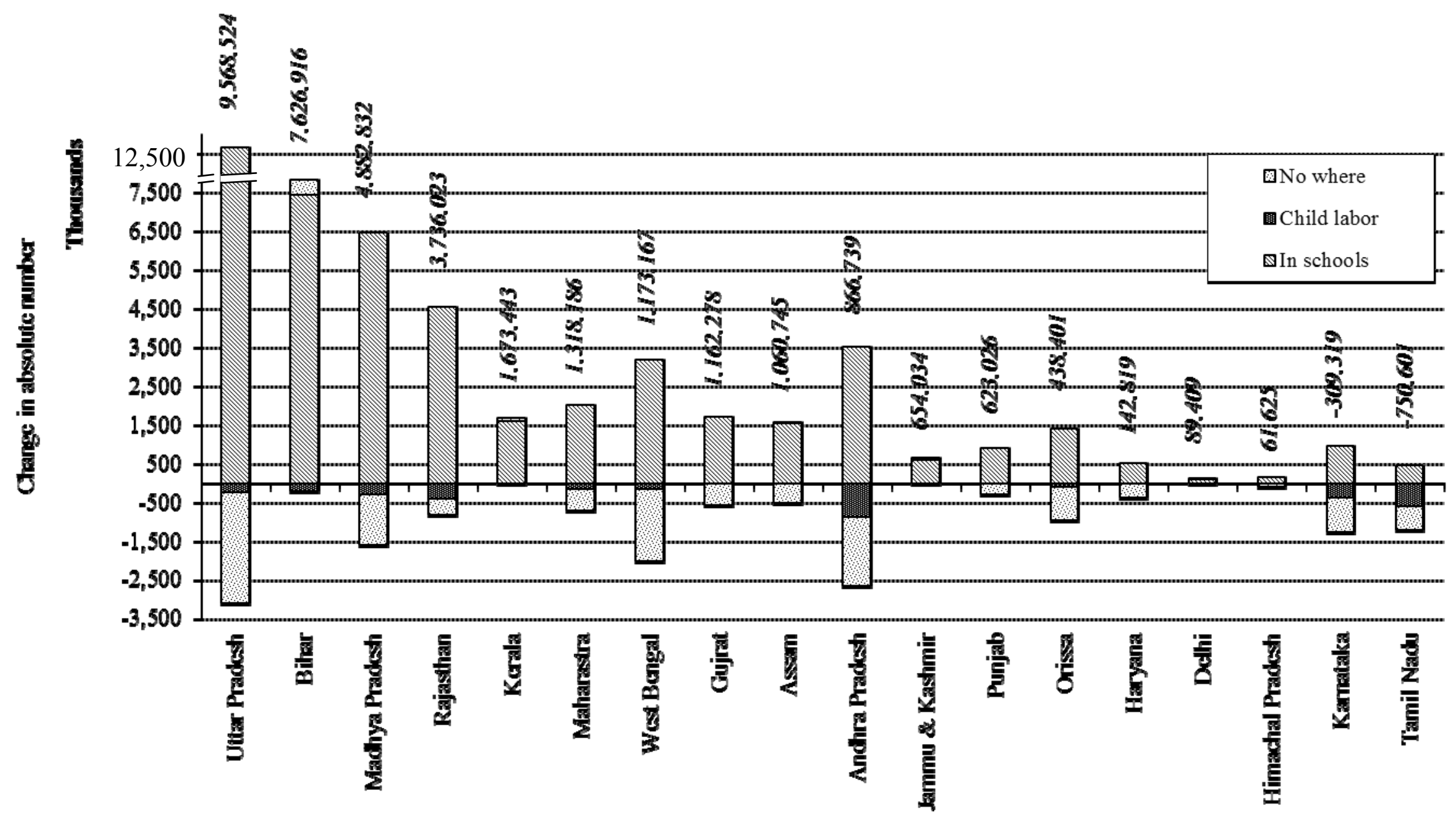

Sources: 1. Computed from NSS 61st Round for 2004-05 and NSS 50th Round for 1993-94

2. Chaudhri \& Jha, 'Child Poverty and Elementary Education in India', ASARC Working Paper 2011/04. 
Figure 8U: Change in children's participation in schooling, child labour and non-participation from 1993-

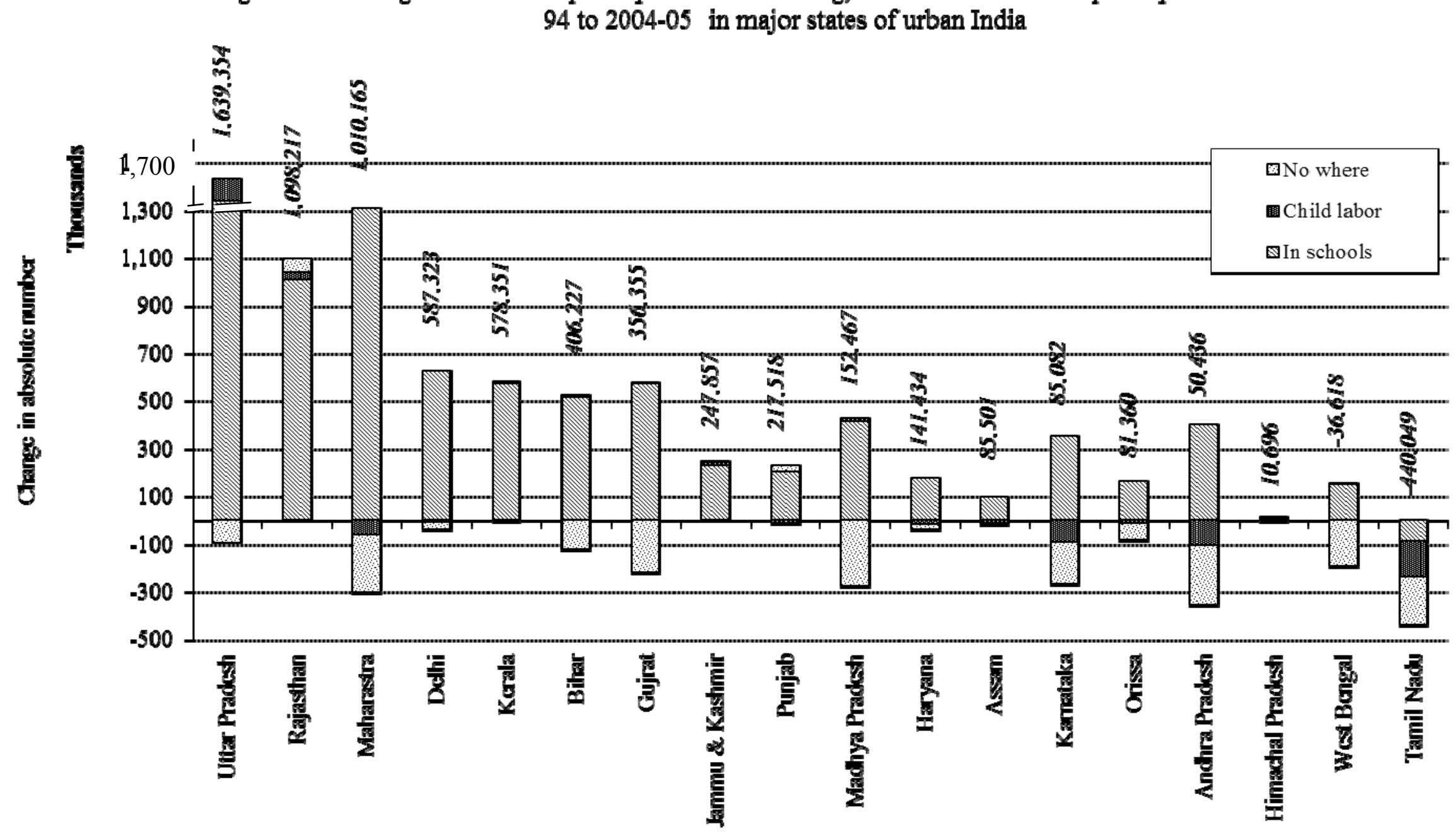


Table 1 - Probit model with interaction terms, Robust SE

(Dependent variable $=1$ if $\mathrm{HH}$ has at least one child aged 5-14 not in school, $=0$ if $\mathrm{HH}$ has all children aged 5-14 in school)

\begin{tabular}{|c|c|c|c|}
\hline Variables & $\begin{array}{c}\text { Coefficient } \\
2004-05\end{array}$ & $\begin{array}{c}\text { Coefficient } \\
\text { 1993-94 }\end{array}$ & $\begin{array}{c}\text { Change } \\
05-93\end{array}$ \\
\hline No. of children aged 0-4 & $0.013(0.009)$ & $0.012(0.008)$ & 0.001 \\
\hline Proportion of girls aged 0-4 to children aged 0-4 & $0.055^{\star * *}(0.019)$ & $0.029 *(0.017)$ & 0.026 \\
\hline No. of children aged 5-14 & $0.268 * \star *(0.007)$ & $0.294^{\star \star \star}$ & $-0.026 * \star *$ \\
\hline Proportion of girls aged 5-14 to children aged 5-14 & $0.149 * * *(0.016)$ & $0.297 * \star *(0.015)$ & $-0.148^{* * *}$ \\
\hline Female headed household & $-0.062^{\star * *}(0.023)$ & $-0.058 * \star(0.025)$ & -0.004 \\
\hline Education share of total expenditure & $-0.129 * * \star(0.006)$ & $-0.074^{\star \star \star}(0.004)$ & $-0.055^{\star \star *}$ \\
\hline Health share of total expenditure & $0.002^{\star \star}(0.001)$ & $0.001 *(0.001)$ & 0.001 \\
\hline Per capita expenditure & $-0.000 * \star *(0.000)$ & $-0.000 * \star *(0.000)$ & $0.000^{* * *}$ \\
\hline Head is illiterate $(\mathrm{HI})$ & $0.757 * \star \star(0.041)$ & $0.807 * \star \star(0.037)$ & -0.050 \\
\hline - HI * Education share of total expenditure & $-0.077^{\star * *}(0.012)$ & $-0.079 * \star *(0.012)$ & 0.002 \\
\hline - HI * Health share of total expenditure & $-0.004^{\star \star}(0.002)$ & $-0.001(0.001)$ & -0.003 \\
\hline - HI * Per capita expenditure & $-0.000 * * *(0.000)$ & $-0.000(0.000)$ & $0.000^{\star * *}$ \\
\hline Scheduled Tribe (ST) & $0.223^{\star \star \star}(0.066)$ & $0.200 * \star \star(0.050)$ & 0.023 \\
\hline - ST * Education share of total expenditure & $-0.007(0.012)$ & $-0.020^{\star *}(0.009)$ & 0.013 \\
\hline - ST * Health share of total expenditure & $-0.002(0.003)$ & $0.004^{* *}(0.002)$ & $-0.006^{*}$ \\
\hline - ST * Per capita expenditure & $-0.000(0.000)$ & $0.000 *(0.000)$ & $0.000 * \star *$ \\
\hline Scheduled Caste (SC) & $0.238 * \star \star(0.048)$ & $0.405^{\star \star \star}(0.059)$ & $-0.167^{\star * *}$ \\
\hline - SC * Education share of total expenditure & $-0.021^{\star *}(0.011)$ & $-0.025(0.021)$ & 0.004 \\
\hline - SC * Health share of total expenditure & $-0.001(0.002)$ & $0.003^{*}(0.002)$ & $-0.004^{* *}$ \\
\hline - SC * Per capita expenditure & $-0.000 *(0.000)$ & $-0.000 * \star \star(0.000)$ & $0.000 * \star *$ \\
\hline Religion is Islam (ISL) & $0.290 * \star \star(0.054)$ & $0.182^{\star \star *}(0.039)$ & $0.108 * *$ \\
\hline - ISL * Education share of total expenditure & $-0.002(0.016)$ & $-0.022^{\star \star \star}(0.008)$ & $0.020 * \star *$ \\
\hline - ISL * Health share of total expenditure & $-0.001(0.002)$ & $-0.000(0.001)$ & -0.001 \\
\hline - ISL * Per capita expenditure & $-0.000(0.000)$ & $0.000 * \star *(0.000)$ & $0.000 * \star *$ \\
\hline Andaman \& Nicobar & $-0.504^{\star * *}(0.148)$ & $-0.197 * \star(0.086)$ & $-0.307^{\star}$ \\
\hline Andhra Pradesh & $-0.123^{\star * \star}(0.043)$ & $-0.007(0.036)$ & $-0.116^{\star *}$ \\
\hline Arunachal Pradesh & $0.396 * \star *(0.055)$ & $-0.040(0.060)$ & $0.436^{\star \star *}$ \\
\hline Assam & $-0.062(0.045)$ & $-0.102^{\star \star \star}(0.042)$ & 0.040 \\
\hline Bihar & $0.475^{\star * *}(0.038)$ & $0.402^{\star \star *}(0.035)$ & 0.073 \\
\hline Chandigarh & $-0.038(0.200)$ & $-0.179(0.210)$ & 0.141 \\
\hline Dadra \& Nagar Haveli & $-0.115(0.154)$ & $0.15(0.106)$ & -0.265 \\
\hline Daman \& Diu & $-0.176(0.218)$ & $-0.521^{\star *}(0.218)$ & 0.345 \\
\hline Delhi & $0.116(0.087)$ & $0.441^{\star \star \star}(0.117)$ & $-0.325^{\star \star *}$ \\
\hline Goa & $-0.429 * \star \star(0.164)$ & $-0.436 * \star \star(0.161)$ & 0.007 \\
\hline Haryana & $0.375^{\star \star \star}(0.056)$ & $0.046(0.056)$ & $0.329 * * *$ \\
\hline Himachal Pradesh & $-0.385^{\star \star \star}(0.067)$ & $-0.251^{\star \star \star}(0.058)$ & -0.134 \\
\hline Jammu \& Kashmir & $0.061(0.058)$ & $0.066(0.065)$ & -0.005 \\
\hline Karnataka & $-0.235^{\star \star *}(0.047)$ & $-0.165^{\star \star *}(0.040)$ & -0.070 \\
\hline Kerala & $-0.323^{\star \star *}(0.049)$ & $-0.670 \star \star *(0.055)$ & $0.347^{\star \star \star}$ \\
\hline Lakshadweep & $-1.269 * \star *(0.215)$ & $-1.757^{\star * \star}(0.155)$ & $0.488^{* *}$ \\
\hline Madhya Pradesh & $0.152 * \star \star(0.039)$ & $0.206 * \star \star(0.035)$ & -0.054 \\
\hline Maharashtra & $-0.189 * * *(0.041)$ & $-0.225^{\star \star *}(0.037)$ & 0.036 \\
\hline Manipur & $0.249 * \star \star(0.059)$ & $-0.129 * *(0.066)$ & $0.378 * \star *$ \\
\hline Meghalaya & $0.110 *(0.067)$ & $0.127^{\star *}(0.063)$ & -0.017 \\
\hline Mizoram & $-0.327 * \star \star(0.090)$ & $-0.029(0.079)$ & $-0.298 * \star *$ \\
\hline Nagaland & $0.419 * \star \star(0.104)$ & $-0.165(0.106)$ & $0.584^{\star \star *}$ \\
\hline Orissa & $0.090 * *(0.045)$ & $0.064(0.040)$ & 0.026 \\
\hline Pondicherry & $-0.869 * \star \star(0.158)$ & $-0.739 * \star \star(0.141)$ & -0.130 \\
\hline Punjab & $0.223^{\star \star *}(0.051)$ & $0.051(0.048)$ & $0.172^{\star \star *}$ \\
\hline Rajasthan & $0.192 * \star *(0.042)$ & $0.330 * \star *(0.039)$ & $-0.138^{* *}$ \\
\hline Sikkim & $-0.319 * * *(0.092)$ & $-0.257^{\star *}(0.113)$ & -0.062 \\
\hline Tamil Nadu & $-0.564 * \star *(0.051)$ & $-0.335^{\star \star \star}(0.040)$ & $-0.229 * \star \star$ \\
\hline Tripura & $0.090(0.060)$ & $-0.101^{*}(0.057)$ & $0.191^{\star *}$ \\
\hline Uttar Pradesh & $0.419 * \star \star(0.038)$ & $0.317^{\star \star \star}(0.034)$ & $0.102^{* *}$ \\
\hline West Bengal & $0.210 * * *(0.043)$ & $0.124^{\star \star *}(0.037)$ & 0.086 \\
\hline Dummy = 1 if rural & $-0.093^{\star * *}(0.015)$ & $0.038^{\star * *}(0.015)$ & $-0.131^{\text {*** }}$ \\
\hline Observations & 68,062 & 64,630 & \\
\hline $\mathrm{Chi}^{2}(56)$ & 8,583 & 10,604 & \\
\hline$p$-value & 0.000 & 0.000 & \\
\hline Pseudo-R² & 0.244 & 0.268 & \\
\hline
\end{tabular}


Table 2 - Multinomial logit model with interaction terms, Robust SE

(Dependent variable $=0$ if $\mathrm{HH}$ with all children aged $5-14$ in school, $=1$ if $\mathrm{HH}$ has at least 1 child aged 5-14 in labour force, $=2$ if $\mathrm{HH}$ has at least 1 child aged 5-14 in no-where)

\begin{tabular}{|c|c|c|c|}
\hline Variables & $\begin{array}{c}\text { Coefficient } \\
2004-05\end{array}$ & $\begin{array}{c}\text { Coefficient } \\
1993-94\end{array}$ & $\begin{array}{c}\text { Change } \\
05-93 \\
\end{array}$ \\
\hline \multicolumn{4}{|c|}{ HH with at least 1 child aged 5-14 in labour force versus $\mathrm{HH}$ with all children aged 5-14 in school } \\
\hline No. of children aged 0-4 & $-0.005^{\star \star \star}(0.052)$ & $-0.010^{\star \star \star}(0.041)$ & 0.005 \\
\hline Proportion of girls aged 0-4 to children aged 0-4 & $-0.002^{*}(0.096)$ & $-0.001(0.072)$ & -0.001 \\
\hline No. of children aged 5-14 & $0.005^{\star \star \star}(0.025)$ & $0.007^{\star \star \star}(0.023)$ & $-0.002^{\star \star *}$ \\
\hline Proportion of girls aged 5-14 to children aged 5-14 & $-0.004^{\star \star \star}(0.070)$ & $-0.007^{\star \star \star}(0.055)$ & $0.003^{\star *}$ \\
\hline Female headed household & $0.002^{\star \star}(0.080)$ & $0.003(0.074)$ & -0.001 \\
\hline Education share of total expenditure & $-0.003^{\star \star \star}(0.037)$ & $-0.003^{\star \star \star}(0.016)$ & 0.000 \\
\hline Health share of total expenditure & $0.000(0.005)$ & $0.000(0.003)$ & 0.000 \\
\hline Per capita expenditure & $0.000(0.000)$ & $0.000(0.000)$ & 0.000 \\
\hline Head is illiterate $(\mathrm{HI})$ & $0.014^{\star \star \star}(0.124)$ & $0.027^{\star \star \star}(0.116)$ & -0.013 \\
\hline - HI * Education share of total expenditure & $-0.002^{\star \star \star}(0.048)$ & $-0.003^{\star \star \star}(0.028)$ & $0.001^{\star *}$ \\
\hline - HI * Health share of total expenditure & $-0.000 *(0.007)$ & $0.000(0.003)$ & $0.000^{*}$ \\
\hline - HI * Per capita expenditure & $0.000(0.000)$ & $-0.000 *(0.000)$ & $0.000^{\star \star}$ \\
\hline Scheduled Tribe (ST) & $0.015^{\star \star \star}(0.167)$ & $0.023^{\star \star \star}(0.170)$ & -0.008 \\
\hline - ST * Education share of total expenditure & $0.000(0.077)$ & $0.000(0.043)$ & 0.000 \\
\hline - ST * Health share of total expenditure & $0.000(0.011)$ & $0.000^{*}(0.006)$ & 0.000 \\
\hline - ST * Per capita expenditure & $-0.000^{\star \star \star}(0.000)$ & $-0.000 * \star(0.001)$ & 0.000 \\
\hline Scheduled Caste (SC) & $0.003(0.183)$ & $0.003^{\star}(0.145)$ & 0.000 \\
\hline - SC * Education share of total expenditure & $0.000(0.064)$ & $0.001(0.042)$ & -0.001 \\
\hline - SC * Health share of total expenditure & $0.000(0.009)$ & $0.000 *(0.004)$ & 0.000 \\
\hline - SC * Per capita expenditure & $0.000(0.000)$ & $-0.000^{\star \star \star}(0.001)$ & $0.000^{*}$ \\
\hline Religion is Islam (ISL) & $0.006^{\star \star \star}(0.184)$ & $0.001(0.118)$ & $0.005^{\star \star}$ \\
\hline - ISL * Education share of total expenditure & $0.001(0.051)$ & $0.001(0.031)$ & 0.000 \\
\hline - ISL * Health share of total expenditure & $0.000(0.009)$ & $0.000(0.005)$ & 0.000 \\
\hline - ISL * Per capita expenditure & $0.000(0.000)$ & $0.000(0.000)$ & 0.000 \\
\hline Andaman \& Nicobar & $-0.009 *(1.021)$ & $0.006(0.317)$ & $-0.015^{\star}$ \\
\hline Andhra Pradesh & $0.017^{\star \star \star}(0.150)$ & $0.076^{\star \star \star}(0.146)$ & $-0.059 * * \star$ \\
\hline Arunachal Pradesh & $-0.003(0.258)$ & $-0.011^{\star \star}(0.308)$ & 0.008 \\
\hline Assam & $-0.002(0.191)$ & $-0.002(0.195)$ & 0.000 \\
\hline Bihar & $-0.005^{\star \star}(0.184)$ & $-0.002(0.173)$ & $-0.003^{*}$ \\
\hline Chandigarh & $-0.005(1.039)$ & $-0.024^{\star \star \star}(0.229)$ & 0.019 \\
\hline Dadra \& Nagar Haveli & $-0.004(0.617)$ & $-0.015(0.731)$ & 0.011 \\
\hline Daman \& Diu & $0.004(0.778)$ & $-0.024^{\star \star \star}(0.230)$ & 0.028 \\
\hline Delhi & $-0.005(0.524)$ & $0.008(0.444)$ & -0.013 \\
\hline Goa & $0.002(0.531)$ & $0.014(0.525)$ & -0.012 \\
\hline Haryana & $0.002(0.272)$ & $0.004(0.274)$ & -0.002 \\
\hline Himachal Pradesh & $-0.003(0.296)$ & $0.026^{\star \star \star}(0.210)$ & $-0.029 * \star \star$ \\
\hline Jammu \& Kashmir & $-0.002(0.263)$ & $0.022^{\star \star \star}(0.271)$ & -0.024 ** \\
\hline Karnataka & $0.005^{\star}(0.171)$ & $0.045^{\star \star *}(0.155)$ & $-0.040 * \star \star$ \\
\hline Kerala & $-0.006^{\star \star \star}(0.239)$ & $-0.013^{\star \star \star}(0.271)$ & 0.007 \\
\hline Lakshadweep & $-0.010 \star \star(1.086)$ & $-0.025^{\star \star \star}(0.239)$ & 0.015 \\
\hline Madhya Pradesh & $0.000(0.163)$ & $0.017^{\star \star \star}(0.154)$ & $-0.017^{\star \star \star *}$ \\
\hline Maharashtra & $0.000(0.163)$ & $0.018^{\star \star \star}(0.154)$ & $-0.018^{\star \star *}$ \\
\hline Manipur & $-0.002(0.320)$ & $-0.008(0.387)$ & 0.006 \\
\hline Meghalaya & $0.010^{\star \star \star}(0.235)$ & $0.009 *(0.274)$ & 0.001 \\
\hline Mizoram & $-0.007^{\star \star}(0.449)$ & $0.005(0.358)$ & $-0.012^{\star \star}$ \\
\hline Nagaland & $-0.009(0.967)$ & $0.001(0.472)$ & -0.010 \\
\hline Orissa & $0.004^{*}(0.176)$ & $0.022^{\star \star \star}(0.167)$ & -0.018 \\
\hline Pondicherry & $-0.010^{\star \star}(1.013)$ & $-0.006(0.583)$ & -0.004 \\
\hline Punjab & $0.005^{\star \star}(0.210)$ & $0.021^{\star \star \star}(0.197)$ & -0.016 \\
\hline Rajasthan & $0.007^{\star \star *}(0.166)$ & $0.068^{* \star *}(0.155)$ & -0.061 *** \\
\hline Sikkim & $0.005(0.301)$ & $-0.019 *(1.015)$ & $0.024^{\star *}$ \\
\hline Tamil Nadu & $0.000(0.182)$ & $0.054^{\star \star \star}(0.150)$ & $-0.054^{\star \star \star}$ \\
\hline Tripura & $-0.002(0.291)$ & $-0.003(0.285)$ & 0.001 \\
\hline Uttar Pradesh & $0.004^{\star \star \star}(0.158)$ & $0.012^{\star \star \star}(0.156)$ & -0.008 \\
\hline West Bengal & $0.008^{\star \star \star}(0.167)$ & $0.021^{\star \star \star}(0.161)$ & -0.013 \\
\hline Dummy = 1 if rural & $-0.001^{\star \star}(0.062)$ & $0.001(0.052)$ & $-0.002^{\star \star \star}$ \\
\hline
\end{tabular}




\begin{tabular}{|c|c|c|c|}
\hline \multicolumn{4}{|c|}{ (Table 2 continued) HH with at least 1 child aged 5-14 in nowhere versus $\mathrm{HH}$ with all children age in school } \\
\hline No. of children aged 0-4 & $0.004^{\star \star \star}(0.016)$ & $0.009^{\star \star *}(0.015)$ & -0.005 \\
\hline Proportion of girls aged 0-4 to children aged 0-4 & $0.011^{\star \star \star}(0.035)$ & $0.011^{* *}(0.031)$ & 0.000 \\
\hline No. of children aged 5-14 & $0.036^{\star \star \star}(0.012)$ & $0.074^{\star \star \star}(0.012)$ & $-0.038^{\star \star \star}$ \\
\hline Proportion of girls aged 5-14 to children aged 5-14 & $0.029^{* \star \star}(0.030)$ & $0.096^{\star \star \star}(0.027)$ & $-0.067^{\star \star \star}$ \\
\hline Female headed household & $-0.013^{\star \star *}(0.043)$ & $-0.016^{\star \star \star}(0.043)$ & 0.003 \\
\hline Education share of total expenditure & $-0.021^{\star \star *}(0.012)$ & $-0.024^{\star \star \star}(0.007)$ & $0.003^{\star \star \star}$ \\
\hline Health share of total expenditure & $0.001^{\star \star *}(0.003)$ & $0.000^{\star \star *}(0.001)$ & 0.001 \\
\hline Per capita expenditure & $-0.000^{\star \star *}(0.000)$ & $-0.000^{\star \star *}(0.000)$ & $0.000^{* \star *}$ \\
\hline Head is illiterate $(\mathrm{HI})$ & $0.104^{\star \star \star}(0.070)$ & $0.211^{\star \star \star}(0.139)$ & $-0.107^{\star \star \star}$ \\
\hline - $\mathrm{HI}{ }^{*}$ Education share of total expenditure & $-0.010^{\star \star *}(0.018)$ & $-0.022^{\star \star \star}(0.013)$ & 0.012 \\
\hline - HI * Health share of total expenditure & $-0.001^{\star \star *}(0.003)$ & $0.000(0.002)$ & $-0.001^{*}$ \\
\hline - HI * Per capita expenditure & -0.000 *** $(0.000)$ & $0.000(0.001)$ & 0.000 \\
\hline Scheduled Tribe (ST) & $0.012(0.103)$ & $0.092^{\star \star \star}(0.116)$ & $-0.080^{\star \star \star}$ \\
\hline - ST * Education share of total expenditure & $-0.002(0.024)$ & $-0.005^{\star}(0.020)$ & 0.003 \\
\hline - ST * Health share of total expenditure & $0.000(0.006)$ & $0.001^{\star \star}(0.004)$ & $-0.001^{*}$ \\
\hline - ST * Per capita expenditure & $0.000(0.000)$ & $-0.000 * \star(0.000)$ & $0.000 * \star *$ \\
\hline Scheduled Caste (SC) & $0.022^{\star \star \star}(0.088)$ & $0.089^{\star \star \star}(0.091)$ & $-0.067^{\star \star \star}$ \\
\hline - SC * Education share of total expenditure & $-0.003^{*}(0.022)$ & $-0.009^{\star \star \star}(0.015)$ & 0.006 \\
\hline - SC * Health share of total expenditure & $-0.001(0.004)$ & $0.001 *(0.002)$ & $-0.002^{\star \star}$ \\
\hline - SC * Per capita expenditure & $0.000(0.000)$ & $0.000(0.000)$ & $0.000^{* *}$ \\
\hline Religion is Islam (ISL) & $0.025^{\star \star \star}(0.092)$ & $0.013(0.170)$ & $0.012^{\star *}$ \\
\hline - ISL * Education share of total expenditure & $-0.001(0.023)$ & $-0.004^{*}(0.015)$ & 0.003 \\
\hline - ISL * Health share of total expenditure & $0.000(0.004)$ & $0.000(0.003)$ & 0.000 \\
\hline - ISL * Per capita expenditure & $0.000 *(0.000)$ & $0.000^{\star \star}(0.001)$ & $0.000^{\star \star *}$ \\
\hline Andaman \& Nicobar & $-0.048^{\star \star \star}(0.301)$ & $-0.031(0.154)$ & $-0.017^{*}$ \\
\hline Andhra Pradesh & $-0.047^{\star \star \star}(0.087)$ & $-0.072^{\star \star \star}(0.067)$ & $0.025^{\star \star \star}$ \\
\hline Arunachal Pradesh & $0.092^{\star \star \star}(0.097)$ & $0.008(0.104)$ & $0.084^{\star \star \star}$ \\
\hline Assam & $-0.006(0.084)$ & $-0.024^{\star \star}(0.073)$ & 0.018 \\
\hline Bihar & $0.098^{\star \star \star}(0.070)$ & $0.127^{\star \star \star}(0.062)$ & $-0.029 *$ \\
\hline Chandigarh & $-0.003(0.378)$ & $-0.012(0.361)$ & 0.009 \\
\hline Dadra \& Nagar Haveli & $-0.017(0.287)$ & $0.054^{*}(0.185)$ & $-0.071^{*}$ \\
\hline Daman \& Diu & $-0.026(0.435)$ & $-0.089 *(0.422)$ & 0.063 \\
\hline Delhi & $0.037^{\star \star \star}(0.159)$ & 0.121 *夫 $(0.191)$ & -0.084 \\
\hline Goa & $-0.057^{\star \star *}(0.400)$ & $-0.102^{\star \star \star}(0.313)$ & 0.045 \\
\hline Haryana & $0.086^{\star \star \star}(0.102)$ & $0.036^{\star *}(0.096)$ & $0.050^{\star \star * *}$ \\
\hline Himachal Pradesh & $-0.043^{\star \star *}(0.139)$ & $-0.069^{\star \star \star}(0.104)$ & 0.026 \\
\hline Jammu \& Kashmir & $0.021^{* *}(0.106)$ & $0.022(0.112)$ & -0.001 \\
\hline Karnataka & $-0.040^{\star \star \star}(0.093)$ & $-0.084^{\star \star \star}(0.074)$ & 0.044 \\
\hline Kerala & $-0.037^{\star \star \star}(0.093)$ & $-0.130^{\star * *}(0.105)$ & $0.093^{\star \star \star}$ \\
\hline Lakshadweep & $-0.079^{\star \star \star}(0.451)$ & $-0.168^{\star \star \star}(0.297)$ & 0.089 \\
\hline Madhya Pradesh & $0.024^{\star \star \star}(0.072)$ & $0.046^{\star \star \star}(0.062)$ & -0.022 \\
\hline Maharashtra & $-0.030^{\star \star *}(0.077)$ & $-0.076^{\star \star \star}(0.066)$ & 0.046 \\
\hline Manipur & $0.062^{\star \star *}(0.108)$ & $-0.014(0.116)$ & $0.076^{\star \star *}$ \\
\hline Meghalaya & $0.018^{*}(0.126)$ & $0.091^{\star \star \star}(0.113)$ & $-0.073^{\star}$ \\
\hline Mizoram & $-0.029^{\star \star \star}(0.164)$ & $0.075^{\star \star *}(0.149)$ & $-0.104^{\star \star \star}$ \\
\hline Nagaland & $0.146^{\star \star \star}(0.186)$ & $0.035(0.202)$ & $0.111^{\star \star \star}$ \\
\hline Orissa & $0.007(0.082)$ & $-0.007(0.072)$ & 0.014 \\
\hline Pondicherry & $-0.071^{\star \star \star}(0.353)$ & $-0.136^{\star \star \star}(0.298)$ & 0.065 \\
\hline Punjab & $0.045^{\star \star \star}(0.095)$ & $0.029^{* * *}(0.083)$ & $0.016^{\star *}$ \\
\hline Rajasthan & $0.025^{\star \star \star}(0.078)$ & $0.056^{\star \star \star}(0.069)$ & -0.031 \\
\hline Sikkim & $-0.049^{\star \star \star}(0.201)$ & $-0.055^{\star \star}(0.190)$ & 0.006 \\
\hline Tamil Nadu & $-0.069^{\star \star *}(0.111)$ & $-0.132^{\star \star \star}(0.078)$ & 0.063 \\
\hline Tripura & $0.020^{\star *}(0.112)$ & $-0.015(0.100)$ & $0.035^{\star *}$ \\
\hline Uttar Pradesh & $0.079 * \star \star(0.070)$ & $0.097^{\star \star \star}(0.059)$ & $-0.018^{\star *}$ \\
\hline West Bengal & $0.032^{\star \star \star}(0.078)$ & $0.020^{* *}(0.066)$ & $0.012^{\star \star}$ \\
\hline Dummy = 1 if rural & $-0.016^{\star \star \star}(0.028)$ & $-0.002(0.026)$ & $-0.014^{\star \star \star}$ \\
\hline Observations & 67376 & 62972 & \\
\hline $\mathrm{Chi}^{2}(112)$ & 9,269 & 146,090 & \\
\hline$p$-value & 0.000 & 0.000 & \\
\hline Pseudo- $\mathrm{R}^{2}$ & 0.229 & 0.247 & \\
\hline
\end{tabular}

Notes: $\quad 1$ Marginal effects; Standard errors in parentheses. Reference state is Gujarat

2. ${ }^{*} p<=0.10,{ }^{* *} p<=0.05,{ }^{* * *} p<=0.01$

Sources: 1. Computed from NSS 61st Round for 2004-05 and NSS 50th Round for 1993-94

2. Chaudhri \& Jha, 'Child Poverty and Elementary Education in India', ASARC Working Paper 2011/04 
Policy Insights from Household Data Analysis

Table A1: Child Population (5-14 years) in Indian States 1961-2005 with Projections to 2026

\begin{tabular}{|c|c|c|c|c|c|c|c|c|c|c|}
\hline States & 1961 & 1971 & 1981 & 1991 & 2001 & NSS 04-05 & $2011^{*}$ & $2016^{*}$ & $2021^{*}$ & $2026^{*}$ \\
\hline Andhra Pradesh & $9,224,996$ & $11,564,453$ & $14,138,294$ & $16,655,656$ & $16,881,000$ & $14,853,069$ & $15,792,000$ & $14,417,000$ & $13,680,000$ & $13,291,000$ \\
\hline Bihar & $7,416,568$ & $9,290,088$ & $10,792,142$ & $13,006,858$ & $29,528,000$ & $25,715,462$ & $31,088,000$ & $29,323,000$ & $26,979,000$ & $26,173,000$ \\
\hline Gujarat & $5,575,323$ & $7,635,236$ & $8,981,496$ & $9,952,794$ & $11,140,000$ & $10,043,867$ & $11,020,000$ & $10,766,000$ & $10,499,000$ & $10,232,000$ \\
\hline Haryana & $2,252,082$ & $3,061,947$ & $3,684,747$ & $4,308,223$ & $5,132,000$ & $4,789,319$ & $5,047,000$ & $4,869,000$ & $4,792,000$ & $4,763,000$ \\
\hline Himachal Pradesh & 670,535 & 930,011 & $1,143,923$ & $1,241,683$ & $1,293,000$ & $1,251,555$ & $1,217,000$ & $1,146,000$ & $1,092,000$ & $1,056,000$ \\
\hline Karnataka & $6,452,716$ & $8,212,931$ & $10,062,257$ & $11,083,831$ & $11,520,000$ & $9,483,237$ & $10,903,000$ & $10,201,000$ & $9,762,000$ & $9,636,000$ \\
\hline Kerala & $4,678,209$ & $5,779,093$ & $6,180,026$ & $5,983,926$ & $5,591,000$ & $6,998,095$ & $5,397,000$ & $5,278,000$ & $5,137,000$ & $4,985,000$ \\
\hline Madhya Pradesh & $7,913,164$ & $11,520,370$ & $14,437,706$ & $16,740,647$ & $20,251,000$ & $20,742,254$ & $20,806,000$ & $20,721,000$ & $20,575,000$ & $20,579,000$ \\
\hline Maharashtra & $10,142,716$ & $13,585,164$ & $16,606,086$ & $18,650,065$ & $20,977,000$ & $18,667,469$ & $20,601,000$ & $20,067,000$ & $19,851,000$ & $19,836,000$ \\
\hline Orissa & $4,369,236$ & $6,169,018$ & $7,334,421$ & $7,704,761$ & $8,266,000$ & $7,908,582$ & $7,988,000$ & $7,369,000$ & $6,881,000$ & $6,659,000$ \\
\hline Punjab & $2,846,380$ & $3,833,832$ & $4,200,614$ & $4,702,876$ & $5,309,000$ & $5,020,821$ & $4,910,000$ & $4,615,000$ & $4,581,000$ & $4,476,000$ \\
\hline Rajasthan & $5,354,581$ & $7,385,480$ & $9,720,864$ & $11,992,321$ & $14,738,000$ & $14,596,185$ & $15,376,000$ & $14,880,000$ & $14,339,000$ & $14,121,000$ \\
\hline Tamil Nadu & $8,057,402$ & $9,922,564$ & $11,555,559$ & $11,979,383$ & $11,610,000$ & $10,362,846$ & $10,743,000$ & $10,295,000$ & $10,032,000$ & $9,605,000$ \\
\hline Uttar Pradesh & $18,889,772$ & $24,004,063$ & $31,280,964$ & $37,021,048$ & $46,883,000$ & $45,537,938$ & $47,682,000$ & $47,428,000$ & $48,968,000$ & $50,472,000$ \\
\hline West Bengal & $9,041,214$ & $12,552,123$ & $14,862,246$ & $17,105,523$ & $18,110,000$ & $17,328,493$ & $17,463,000$ & $15,709,000$ & $14,063,000$ & $13,660,000$ \\
\hline Others & $11,095,250$ & $15,391,836$ & $14,615,900$ & $21,857,035$ & $15,957,000$ & $12,834,238$ & $14,980,000$ & $14,959,000$ & $15,947,000$ & $16,728,000$ \\
\hline India & $113,980,144$ & $150,838,209$ & $179,597,245$ & $209,986,630$ & $243,186,000$ & $226,133,430$ & $232,064,000$ & $226,190,000$ & $225,491,000$ & $222,420,000$ \\
\hline
\end{tabular}

Sources: Census of India 1961, 1971, 1981, 1991, 2001, NSS 61'st Round for 2005, and Population Projections for India and States $2001-2026$ (Census of India 2001 ). Chaudhri \& Jha, 'Child Poverty and Elementary Education in India', ASARC Working Paper 2011/04. 
Table A2: Total fertility rates in major states of India 1961-2001

\begin{tabular}{lccccc}
\hline States & 1961 & $\mathbf{1 9 7 1}$ & $\mathbf{1 9 8 1}$ & 1991 & $\mathbf{2 0 0 1}$ \\
\hline Andhra Pradesh & 4.6 & 4.6 & 4.0 & 2.8 & 2.1 \\
Bihar & 7.9 & 5.6 & 5.7 & 4.6 & 3.9 \\
Jharkhand & 7.9 & 5.6 & 5.7 & 4.6 & 3.3 \\
Gujarat & 7.1 & 5.6 & 4.3 & 3.2 & 2.6 \\
Haryana & 8.9 & 6.7 & 5.0 & 3.8 & 2.8 \\
Himachal Pradesh & 6.7 & 5.2 & 3.8 & 3.1 & 2.1 \\
Karnataka & 5.3 & 4.4 & 3.6 & 2.9 & 2.2 \\
Kerala & 5.6 & 4.1 & 2.8 & 1.7 & 1.8 \\
Madhya Pradesh & 5.6 & 5.6 & 5.2 & 4.4 & 3.7 \\
Chhattisgarh & 5.6 & 5.6 & 5.2 & 4.4 & 3.3 \\
Maharashtra & 5.9 & 4.6 & 3.6 & 2.9 & 2.4 \\
Orissa & 4.3 & 4.7 & 4.3 & 3.1 & 2.5 \\
Punjab & 6.7 & 5.2 & 4.0 & 3.1 & 2.3 \\
Rajasthan & 6.6 & 6.2 & 5.2 & 4.5 & 3.6 \\
Tamil Nadu & 3.7 & 3.9 & 3.4 & 2.2 & 1.9 \\
Uttar Pradesh & 7.6 & 6.6 & 5.8 & 5.2 & 4.4 \\
Uttaranchal & 7.6 & 6.6 & 5.8 & 5.2 & 3.2 \\
West Bengal & 6.8 & 5.4 & 4.2 & 2.9 & 2.2 \\
\hline All India & 6.1 & 6.5 & 5.4 & 4.6 & $\mathbf{2 . 9}$ \\
\hline
\end{tabular}

Sources: 1. Census of India 1961, 1971, 1981, 1991 and 2001

2. Ron C . Mittelhammer, Tauhidur Rahman (2004), Distribution of Human Development, Child Labor and Poverty in India.

3. National Commission on Population MHFW 2006

4. Chaudhri \& Jha, 'Child Poverty and Elementary Education in India', ASARC Working Paper 2011/04.

Table A3: Household size, number of children (0-14) in poor and non poor households in India

\begin{tabular}{l|cccc|cccc}
\hline & \multicolumn{4}{|c|}{$2004-05$} & \multicolumn{4}{c}{$1993-14$} \\
\cline { 2 - 9 } & $\begin{array}{c}\text { Very } \\
\text { poor }\end{array}$ & $\begin{array}{c}\text { Moderately } \\
\text { poor }\end{array}$ & $\begin{array}{c}\text { Non- } \\
\text { poor low }\end{array}$ & $\begin{array}{c}\text { Non-poor } \\
\text { high }\end{array}$ & $\begin{array}{c}\text { Very } \\
\text { poor }\end{array}$ & $\begin{array}{c}\text { Moderately } \\
\text { poor }\end{array}$ & $\begin{array}{c}\text { Non- } \\
\text { poor low }\end{array}$ & $\begin{array}{c}\text { Non-poor } \\
\text { high }\end{array}$ \\
\hline Family size* & 5.5 & 5.8 & 5.1 & 3.9 & 5.8 & 5.6 & 5.0 & 3.9 \\
Children+ & 2.6 & 2.4 & 1.7 & 0.9 & 2.9 & 2.4 & 1.7 & 1.0 \\
Adults & 2.9 & 3.4 & 3.4 & 3.0 & 2.9 & 3.2 & 3.3 & 2.9 \\
\hline
\end{tabular}

Sources: 1. Computed from NSS 61st Round for 2004-05 and NSS 50th Round for 1993-94

2. 'Poverty estimates for 2004-05', Press Information Bureau of Government of India, New Delhi, March-2007

3. Savita Sarma, 'Poverty Estimates in India: Some key issues', ERD Working Paper Series No. 51, ADB, May 2004.

4. Chaudhri \& Jha, 'Child Poverty and Elementary Education in India', ASARC Working Paper 2011/04.

Notes: * all pairwise comparisons of differences in mean values of household size are statistically significant at $1 \%$ within the two samples and also between 1993-94 and 2004-05

+ all pairwise comparisons of differences in mean values of number of children are statistically significant at $1 \%$ within the two samples and also between 1993-94 and 2004-05 
Table A4: Child poverty in 2004-05 and 1993-94 in major states of India

\begin{tabular}{|c|c|c|c|c|c|c|}
\hline & \multicolumn{3}{|c|}{ 2004-05 } & \multicolumn{3}{|c|}{ 1993-94 } \\
\hline & $0-4$ & $5-9$ & $0-14$ & $0-4$ & $5-9$ & $0-14$ \\
\hline All India & $34,279,542$ & $38,225,253$ & $103,931,034$ & $43,930,219$ & $43,880,663$ & $121,678,168$ \\
\hline \multicolumn{7}{|l|}{ States } \\
\hline Andhra Pradesh & $1,005,236$ & $1,345,199$ & $3,718,001$ & $2,166,667$ & $2,206,538$ & $5,807,373$ \\
\hline Assam & 602,240 & 810,275 & $1,993,848$ & $1,147,749$ & $1,293,210$ & $3,570,004$ \\
\hline Bihar & $5,833,646$ & $6,060,077$ & $16,182,531$ & $6,574,326$ & $6,120,688$ & $17,116,611$ \\
\hline Dadra \& Nagar Haveli & 7,258 & 6,633 & 17,249 & 10,503 & 10,467 & 27,437 \\
\hline Delhi & 159,186 & 169,683 & 509,644 & 193,209 & 202,298 & 510,440 \\
\hline Gujarat & 870,607 & $1,039,858$ & $2,724,786$ & $1,358,690$ & $1,264,251$ & $3,556,418$ \\
\hline Haryana & 465,713 & 458,633 & $1,259,855$ & 783,913 & 696,623 & $2,078,702$ \\
\hline Himachal Pradesh & 70,701 & 77,088 & 224,587 & 220,227 & 201,597 & 609,203 \\
\hline Jammu \& Kashmir & 26,618 & 36,936 & 98,449 & 68,045 & 65,932 & 180,359 \\
\hline Karnataka & $1,254,864$ & $1,410,069$ & $3,973,940$ & $1,972,297$ & $2,119,073$ & $5,865,050$ \\
\hline Kerala & 876,772 & 938,864 & $2,592,934$ & 662,034 & 724,329 & $2,177,746$ \\
\hline Madhya Pradesh & $3,890,722$ & $4,534,772$ & $11,946,556$ & $4,282,661$ & $4,161,953$ & $11,524,453$ \\
\hline Maharashtra & $3,242,095$ & $3,234,186$ & $9,642,228$ & $3,526,481$ & $3,583,189$ & $9,763,367$ \\
\hline Orissa & $2,026,434$ & $2,096,754$ & $5,951,422$ & $2,165,624$ & $2,300,113$ & $6,206,286$ \\
\hline Punjab & 294,447 & 336,933 & 895,156 & 445,909 & 383,822 & $1,149,841$ \\
\hline Rajasthan & $1,722,491$ & $1,995,041$ & $5,297,573$ & $1,928,256$ & $1,673,605$ & $4,807,930$ \\
\hline Tamil Nadu & $1,138,120$ & $1,401,304$ & $3,914,075$ & $1,995,475$ & $2,235,256$ & $6,569,147$ \\
\hline Uttar Pradesh & $7,861,438$ & $8,877,201$ & $23,748,467$ & $10,163,387$ & $9,475,490$ & $26,909,218$ \\
\hline West Bengal & $2,697,424$ & $3,197,099$ & $8,558,785$ & $3,956,057$ & $4,583,456$ & $11,825,806$ \\
\hline
\end{tabular}

Sources: 1. Computed from NSS 61st Round for 2004-05 and NSS 50th Round for 1993-94

2. Chaudhri \& Jha, 'Child Poverty and Elementary Education in India', ASARC Working Paper 2011/04. 
Child Poverty and Compulsory Elementary Education in India:

Table A4R: Child poverty in 2004-05 and 1993-94 in major states of rural India

\begin{tabular}{|c|c|c|c|c|c|c|}
\hline & \multicolumn{3}{|c|}{$2004-05$} & \multicolumn{3}{|c|}{$1993-94$} \\
\hline & $0-4$ & $5-9$ & $0-14$ & $0-4$ & $5-9$ & $0-14$ \\
\hline All Rural India & $26,711,499$ & $29,700,332$ & $79,628,902$ & $35,116,471$ & $34,741,658$ & $95,556,999$ \\
\hline States & & & & & & \\
\hline Andhra Pradesh & 553,239 & 777,788 & $2,097,968$ & $1,303,051$ & $1,296,938$ & $3,335,776$ \\
\hline Assam & 590,966 & 798,796 & $1,965,244$ & $1,126,207$ & $1,268,425$ & $3,499,818$ \\
\hline Bihar & $5,443,844$ & $5,639,137$ & $14,969,416$ & $6,067,588$ & $5,627,186$ & $15,724,598$ \\
\hline Dadra \& Nagar Haveli & 6,946 & 6,047 & 15,896 & 9,933 & 9,994 & 26,008 \\
\hline Delhi & 5,450 & 5,450 & 13,625 & 4,292 & 4,292 & 8,584 \\
\hline Gujarat & 667,052 & 781,858 & $2,052,435$ & $1,019,620$ & 898,303 & $2,571,815$ \\
\hline Haryana & 361,390 & 335,331 & 927,702 & 659,565 & 585,426 & $1,756,903$ \\
\hline Himachal Pradesh & 58,046 & 71,629 & 197,705 & 211,991 & 193,096 & 581,744 \\
\hline Jammu \& Kashmir & 17,668 & 22,289 & 58,115 & 62,585 & 58,059 & 156,878 \\
\hline Karnataka & 808,709 & 889,784 & $2,456,337$ & $1,336,402$ & $1,417,141$ & $3,827,465$ \\
\hline Kerala & 663,659 & 719,668 & $1,951,064$ & 486,175 & 526,379 & $1,607,547$ \\
\hline Madhya Pradesh & $3,024,822$ & $3,570,017$ & $9,078,394$ & $3,320,614$ & $3,204,599$ & $8,734,083$ \\
\hline Maharashtra & $1,775,378$ & $1,797,149$ & $5,251,037$ & $2,780,073$ & $2,796,408$ & $7,543,720$ \\
\hline Orissa & $1,757,449$ & $1,832,040$ & $5,170,990$ & $1,967,285$ & $2,096,708$ & $5,606,980$ \\
\hline Punjab & 238,693 & 268,291 & 721,417 & 280,562 & 239,546 & 713,473 \\
\hline Rajasthan & $1,149,838$ & $1,309,777$ & $3,453,100$ & $1,550,343$ & $1,321,412$ & $3,818,644$ \\
\hline Tamil Nadu & 728,910 & 861,776 & $2,461,207$ & $1,420,706$ & $1,646,965$ & $4,600,320$ \\
\hline Uttar Pradesh & $6,408,265$ & $7,101,511$ & $18,879,082$ & $7,963,543$ & $7,368,921$ & $20,843,447$ \\
\hline West Bengal & $2,446,410$ & $2,887,280$ & $7,674,980$ & $3,313,055$ & $3,770,893$ & $9,612,625$ \\
\hline
\end{tabular}

Table A4U: Child poverty in 2004-05 and 1993-94 in major states of urban India

\begin{tabular}{|c|c|c|c|c|c|c|}
\hline & \multicolumn{3}{|c|}{ 2004-05 } & \multicolumn{3}{|c|}{$1993-94$} \\
\hline & $0-4$ & $5-9$ & $0-14$ & $0-4$ & $5-9$ & $0-14$ \\
\hline All Urban India & $7,568,043$ & $8,524,921$ & $24,302,132$ & $8,813,748$ & $9,139,005$ & $26,121,169$ \\
\hline States & & & & & & \\
\hline Andhra Pradesh & 451,997 & 567,411 & $1,620,033$ & 863,616 & 909,600 & $2,471,597$ \\
\hline Assam & 11,274 & 11,479 & 28,604 & 21,542 & 24,785 & 70,186 \\
\hline Bihar & 389,802 & 420,940 & $1,213,115$ & 506,738 & 493,502 & $1,392,013$ \\
\hline Dadra \& Nagar Haveli & 312 & 586 & 1,353 & 570 & 473 & 1,429 \\
\hline Delhi & 153,736 & 164,233 & 496,019 & 188,917 & 198,006 & 501,856 \\
\hline Gujarat & 203,555 & 258,000 & 672,351 & 339,070 & 365,948 & 984,603 \\
\hline Haryana & 104,323 & 123,302 & 332,153 & 124,348 & 111,197 & 321,799 \\
\hline Himachal Pradesh & 12,655 & 5,459 & 26,882 & 8,236 & 8,501 & 27,459 \\
\hline Jammu \& Kashmir & 8,950 & 14,647 & 40,334 & 5,460 & 7,873 & 23,481 \\
\hline Karnataka & 446,155 & 520,285 & $1,517,603$ & 635,895 & 701,932 & $2,037,585$ \\
\hline Kerala & 213,113 & 219,196 & 641,870 & 175,859 & 197,950 & 570,199 \\
\hline Madhya Pradesh & 865,900 & 964,755 & $2,868,162$ & 962,047 & 957,354 & $2,790,370$ \\
\hline Maharashtra & $1,466,717$ & $1,437,037$ & $4,391,191$ & 746,408 & 786,781 & $2,219,647$ \\
\hline Orissa & 268,985 & 264,714 & 780,432 & 198,339 & 203,405 & 599,306 \\
\hline Punjab & 55,754 & 68,642 & 173,739 & 165,347 & 144,276 & 436,368 \\
\hline Rajasthan & 572,653 & 685,264 & $1,844,473$ & 377,913 & 352,193 & 989,286 \\
\hline Tamil Nadu & 409,210 & 539,528 & $1,452,868$ & 574,769 & 588,291 & $1,968,827$ \\
\hline Uttar Pradesh & $1,453,173$ & $1,775,690$ & $4,869,385$ & $2,199,844$ & $2,106,569$ & $6,065,771$ \\
\hline West Bengal & 251,014 & 309,819 & 883,805 & 643,002 & 812,563 & $2,213,181$ \\
\hline
\end{tabular}

Sources: For Tables A4R \& A4U: Computed from NSS 61st Round for 2004-05 and NSS 50th Round for 1993-94; Chaudhri \& Jha, 'Child Poverty and Elementary Education in India', ASARC Working Paper 2011/04. 
Policy Insights from Household Data Analysis

Table A5: Change in child poverty from 1993 to 2005 in major states of India

\begin{tabular}{|c|c|c|c|c|c|c|c|c|c|}
\hline & \multicolumn{3}{|c|}{ Total } & \multicolumn{3}{|c|}{ Rural } & \multicolumn{3}{|c|}{ Urban } \\
\hline & $0-4$ & 5-9 & $0-14$ & $0-4$ & 5-9 & $0-14$ & $0-4$ & 5-9 & $0-14$ \\
\hline All India & $-9,650,677$ & $-5,655,410$ & $-17,747,134$ & $-8,404,972$ & $-5,041,326$ & $-15,928,097$ & $-1,245,705$ & $-614,084$ & $-1,819,037$ \\
\hline States & & & & & & & & & \\
\hline Andhra Pradesh & $-1,161,431$ & $-861,339$ & $-2,089,372$ & $-749,812$ & $-519,150$ & $-1,237,808$ & $-411,619$ & $-342,189$ & $-851,564$ \\
\hline Assam & $-545,509$ & $-482,935$ & $-1,576,156$ & $-535,241$ & $-469,629$ & $-1,534,574$ & $-10,268$ & $-13,306$ & $-41,582$ \\
\hline Bihar & $-740,680$ & $-60,611$ & $-934,080$ & $-623,744$ & 11,951 & $-755,182$ & $-116,936$ & $-72,562$ & $-178,898$ \\
\hline Dadra \& Nagar Haveli & $-3,245$ & $-3,834$ & $-10,188$ & $-2,987$ & $-3,947$ & $-10,112$ & -258 & 113 & -76 \\
\hline Delhi & $-34,023$ & $-32,615$ & -796 & 1,158 & 1,158 & 5,041 & $-35,181$ & $-33,773$ & $-5,837$ \\
\hline Gujarat & $-488,083$ & $-224,393$ & $-831,632$ & $-352,568$ & $-116,445$ & $-519,380$ & $-135,515$ & $-107,948$ & $-312,252$ \\
\hline Haryana & $-318,200$ & $-237,990$ & $-818,847$ & $-298,175$ & $-250,095$ & $-829,201$ & $-20,025$ & 12,105 & 10,354 \\
\hline Himachal Pradesh & $-149,526$ & $-124,509$ & $-384,616$ & $-153,945$ & $-121,467$ & $-384,039$ & 4,419 & $-3,042$ & -577 \\
\hline Jammu \& Kashmir & $-41,427$ & $-28,996$ & $-81,910$ & $-44,917$ & $-35,770$ & $-98,763$ & 3,490 & 6,774 & 16,853 \\
\hline Karnataka & $-717,433$ & $-709,004$ & $-1,891,110$ & $-527,693$ & $-527,357$ & $-1,371,128$ & $-189,740$ & $-181,647$ & $-519,982$ \\
\hline Kerala & 214,738 & 214,535 & 415,188 & 177,484 & 193,289 & 343,517 & 37,254 & 21,246 & 71,671 \\
\hline Madhya Pradesh & $-391,939$ & 372,819 & 422,103 & $-295,792$ & 365,418 & 344,311 & $-96,147$ & 7,401 & 77,792 \\
\hline Maharashtra & $-284,386$ & $-349,003$ & $-121,139$ & $-1,004,695$ & $-999,259$ & $-2,292,683$ & 720,309 & 650,256 & $2,171,544$ \\
\hline Orissa & $-139,190$ & $-203,359$ & $-254,864$ & $-209,836$ & $-264,668$ & $-435,990$ & 70,646 & 61,309 & 181,126 \\
\hline Punjab & $-151,462$ & $-46,889$ & $-254,685$ & $-41,869$ & 28,745 & 7,944 & $-109,593$ & $-75,634$ & $-262,629$ \\
\hline Rajasthan & $-205,765$ & 321,436 & 489,643 & $-400,505$ & $-11,635$ & $-365,544$ & 194,740 & 333,071 & 855,187 \\
\hline Tamil Nadu & $-857,355$ & $-833,952$ & $-2,655,072$ & $-691,796$ & $-785,189$ & $-2,139,113$ & $-165,559$ & $-48,763$ & $-515,959$ \\
\hline Uttar Pradesh & $-2,301,949$ & $-598,289$ & $-3,160,751$ & $-1,555,278$ & $-267,410$ & $-1,964,365$ & $-746,671$ & $-330,879$ & $-1,196,386$ \\
\hline West Bengal & $-1,258,633$ & $-1,386,357$ & $-3,267,021$ & $-866,645$ & $-883,613$ & $-1,937,645$ & $-391,988$ & $-502,744$ & $-1,329,376$ \\
\hline
\end{tabular}

Sources: 1. Computed from NSS 61st Round for 2004-05 and NSS 50th Round for 1993-94

2. Chaudhri \& Jha, 'Child Poverty and Eementary Education in India', ASARC Working Paper 2011/04. 
Child Poverty and Compulsory Elementary Education in India:

Table A6: Child population (5-14) in schools, in labor force and nowhere by poverty status in India, 2004-2005 and 1993-94

\begin{tabular}{|c|c|c|c|c|c|c|c|c|}
\hline & \multicolumn{4}{|c|}{$2004-05$} & \multicolumn{4}{|c|}{$1993-94$} \\
\hline & $\begin{array}{c}\text { Total } \\
\text { (million) }\end{array}$ & $\begin{array}{c}\text { In schools } \\
\text { (\%) }\end{array}$ & $\begin{array}{c}\text { Child labour } \\
\text { (\%) }\end{array}$ & $\begin{array}{l}\text { No where } \\
\text { (\%) }\end{array}$ & $\begin{array}{l}\text { Total } \\
\text { (million) }\end{array}$ & $\begin{array}{c}\text { In schools } \\
\text { (\%) }\end{array}$ & $\begin{array}{c}\text { Child labour } \\
\text { (\%) }\end{array}$ & $\begin{array}{c}\text { No where } \\
\text { (\%) }\end{array}$ \\
\hline Ultra poor & 28 & 66.4 & 4.4 & 29.2 & 5.4 & 41.8 & 8.2 & 50.0 \\
\hline Poor & 66.8 & 72.3 & 3.3 & 24.3 & 723 & 57.6 & 6.0 & 36.4 \\
\hline Non-poor low & 124.6 & 84.4 & 2.3 & 13.4 & 85.6 & 74.6 & 4.4 & 21.0 \\
\hline Non-poor high & 319 & 95.1 & 1.0 & 3.9 & 220 & 86.9 & 2.8 & 10.4 \\
\hline Total & 226.1 & 821 & 2.4 & 15.5 & 185.4 & 68.4 & 5.0 & 26.6 \\
\hline
\end{tabular}

Sources: 1. Computed from NSS 61st Round for 2004-05 and NSS 50th Round for 1993-94

2. Chaudhri \& Jha, 'Child Poverty and Eementary Education in India', ASARC Working Paper 2011/04. 
Policy Insights from Household Data Analysis

Table A7: Child population (5 to 14 years) in major states of India 2004-05 and 1993-94

a) 2004-05

\begin{tabular}{|c|c|c|c|c|c|c|c|c|c|c|c|c|}
\hline & \multicolumn{4}{|c|}{ Total } & \multicolumn{4}{|c|}{ Poverty } & \multicolumn{4}{|c|}{ Non-poverty } \\
\hline & $\begin{array}{c}\text { Child } \\
\text { population }\end{array}$ & $\begin{array}{l}\text { In schools } \\
\text { (\% of (1)) }\end{array}$ & $\begin{array}{l}\text { Child labor } \\
\text { (\% of (1)) }\end{array}$ & $\begin{array}{l}\text { No where } \\
\text { (\% of (1)) }\end{array}$ & $\begin{array}{c}\text { Child } \\
\text { population }\end{array}$ & $\begin{array}{l}\text { In schools } \\
\text { (\% of (5)) }\end{array}$ & $\begin{array}{c}\text { Child labor } \\
\text { (\% of (5)) }\end{array}$ & $\begin{array}{l}\text { No where } \\
\text { (\% of (5)) }\end{array}$ & $\begin{array}{c}\text { Child } \\
\text { population }\end{array}$ & $\begin{array}{l}\text { In schools } \\
\text { (\% of (9)) }\end{array}$ & $\begin{array}{l}\text { Child labor } \\
\text { (\% of (9)) }\end{array}$ & $\begin{array}{l}\text { No where } \\
\text { (\% of (9)) }\end{array}$ \\
\hline & (1) & (2) & (3) & (4) & (5) & (6) & $(7)$ & (8) & (9) & (10) & (11) & (12) \\
\hline All India & $226,133,430$ & 82.1 & 24 & 15.5 & $69,651,492$ & 721 & 3.4 & 24.5 & $156,481,938$ & 86.5 & 20 & 114 \\
\hline \multicolumn{13}{|l|}{ States } \\
\hline Andhra Pradesh & $14,853,069$ & 87.6 & 5.9 & 6.4 & $2,712,765$ & 85.7 & 6.8 & 7.5 & $12,140,304$ & 88.1 & 5.8 & 6.2 \\
\hline Assam & $6,177,458$ & 87.1 & 1.5 & 11.3 & $1,391,608$ & 80.1 & 1.6 & 18.3 & $4,785,850$ & 89.2 & 1.5 & 9.3 \\
\hline Bihar & $25,715,462$ & 67.8 & 1.3 & 30.9 & $10,348,885$ & 54.4 & 1.9 & 43.7 & $15,366,577$ & 76.8 & 0.9 & 22.3 \\
\hline Dadra \& Nagar Haveli & 40,605 & 84.2 & 1.6 & 14.2 & 9,991 & 71.9 & 1.5 & 26.6 & 30,614 & 88.2 & 1.6 & 10.2 \\
\hline Delhi & $2,293,883$ & 90.3 & 0.3 & 9.5 & 350,458 & 75.8 & 1.0 & 23.2 & $1,943,425$ & 92.9 & 0.1 & 7.0 \\
\hline Goa & 171,089 & 94.6 & 2.7 & 2.7 & 22,173 & 90.7 & 1.2 & 8.1 & 148,916 & 95.2 & 2.9 & 1.9 \\
\hline Gujarat & $10,043,867$ & 85.6 & 2.0 & 12.4 & $1,854,179$ & 79.2 & 2.7 & 18.0 & 8,189,688 & 87.0 & 1.9 & 11.1 \\
\hline Haryana & $4,789,319$ & 87.2 & 0.7 & 12.1 & 794,142 & 71.1 & 1.1 & 27.8 & $3,995,177$ & 90.4 & 0.6 & 9.0 \\
\hline Himachal Pradesh & $1,251,555$ & 95.0 & 1.1 & 4.0 & 153,886 & 85.7 & 3.8 & 10.5 & $1,097,669$ & 96.3 & 0.7 & 3.1 \\
\hline Jammu \& Kashmir & $1,482,166$ & 88.1 & 2.3 & 9.6 & 71,831 & 69.1 & 13.2 & 17.7 & 1,410,335 & 89.1 & 1.7 & 9.2 \\
\hline Karnataka & $9,483,237$ & 88.3 & 4.1 & 7.6 & $2,719,076$ & 81.0 & 4.5 & 14.5 & $6,764,161$ & 91.2 & 4.0 & 4.8 \\
\hline Kerala & $6,998,095$ & 94.9 & 0.4 & 4.6 & $1,716,162$ & 88.4 & 1.0 & 10.7 & $5,281,933$ & 97.1 & 0.3 & 2.6 \\
\hline Madhya Pradesh & $20,742,254$ & 79.0 & 2.5 & 18.4 & $8,055,834$ & 72.1 & 3.1 & 24.8 & $12,686,420$ & 83.5 & 2.2 & 14.4 \\
\hline Maharashtra & $18,667,469$ & 89.1 & 2.5 & 8.4 & $6,400,133$ & 82.8 & 3.2 & 14.0 & $12,267,336$ & 92.4 & 2.1 & 5.4 \\
\hline Orissa & $7,908,582$ & 80.2 & 3.6 & 16.3 & $3,924,988$ & 73.6 & 4.5 & 21.9 & $3,983,594$ & 86.7 & 2.7 & 10.7 \\
\hline Punjab & $5,020,821$ & 89.0 & 1.2 & 9.8 & 600,709 & 68.3 & 2.2 & 29.5 & $4,420,112$ & 91.8 & 1.1 & 7.1 \\
\hline Rajasthan & $14,596,185$ & 78.0 & 3.8 & 18.2 & $3,575,082$ & 67.0 & 5.7 & 27.3 & $11,021,103$ & 81.6 & 3.2 & 15.2 \\
\hline Tamil Nadu & $10,362,846$ & 96.1 & 1.4 & 2.5 & $2,775,955$ & 93.6 & 2.1 & 4.3 & $7,586,891$ & 97.0 & 1.2 & 1.8 \\
\hline Uttar Pradesh & $45,537,938$ & 77.5 & 2.1 & 20.3 & $15,887,029$ & 69.4 & 2.9 & 27.7 & $29,650,909$ & 81.9 & 1.8 & 16.4 \\
\hline West Bengal & $17,328,493$ & 82.9 & 2.6 & 14.5 & $5,861,361$ & 70.6 & 3.8 & 25.6 & $11,467,132$ & 89.2 & 1.9 & 8.9 \\
\hline
\end{tabular}


Table A7 (continued)

b) 1993-94

\begin{tabular}{|c|c|c|c|c|c|c|c|c|c|c|c|c|}
\hline & \multicolumn{4}{|c|}{ Total } & \multicolumn{4}{|c|}{ Poverty } & \multicolumn{4}{|c|}{ Non-poverty } \\
\hline & $\begin{array}{c}\text { Child } \\
\text { population }\end{array}$ & $\begin{array}{c}\text { In schools } \\
\text { (\% of (1)) }\end{array}$ & $\begin{array}{c}\text { Child labor } \\
\text { (\% of (1)) }\end{array}$ & $\begin{array}{r}\text { No where } \\
\text { (\% of (1)) }\end{array}$ & $\begin{array}{c}\text { Child } \\
\text { population }\end{array}$ & $\begin{array}{l}\text { In schools } \\
\text { (\% of (5)) }\end{array}$ & $\begin{array}{c}\text { Child labor } \\
\text { (\% of (5)) }\end{array}$ & $\begin{array}{l}\text { No where } \\
\text { (\% of (5)) }\end{array}$ & $\begin{array}{c}\text { Child } \\
\text { population }\end{array}$ & $\begin{array}{l}\text { In schools } \\
\text { (\% of (9)) }\end{array}$ & $\begin{array}{l}\text { Child labor } \\
\text { (\% of (9)) }\end{array}$ & $\begin{array}{r}\text { No where } \\
\text { (\% of (9)) }\end{array}$ \\
\hline & (1) & (2) & (3) & (4) & (5) & (6) & (7) & (8) & (9) & (10) & (11) & (12) \\
\hline $\begin{array}{l}\text { All India } \\
\text { States }\end{array}$ & $185,306,273$ & 68.4 & 5.0 & 26.6 & $77,747,949$ & 56.4 & 6.2 & 37.4 & $15,890,601$ & 52.1 & 10.2 & 37.7 \\
\hline Andhra Pradesh & $13,935,894$ & 65.2 & 13.4 & 21.4 & $3,640,706$ & 58.5 & 12.9 & 28.6 & $1,037,341$ & 40.6 & 31.3 & 28.1 \\
\hline Assam & $5,031,212$ & 74.2 & 1.9 & 23.9 & $2,422,255$ & 65.8 & 2.4 & 31.8 & 654,587 & 81.4 & 0.5 & 18.1 \\
\hline Bihar & $17,682,319$ & 53.6 & 3.0 & 43.5 & $10,542,285$ & 43.3 & 3.5 & 53.2 & $1,356,185$ & 43.3 & 6.3 & 50.4 \\
\hline Dadra \& Nagar Haveli & 26,592 & 58.2 & 1.6 & 40.2 & 16,934 & 52.2 & 1.3 & 46.5 & 23,630 & 54.3 & 1.8 & 43.9 \\
\hline Delhi & $1,617,151$ & 83.9 & 0.8 & 15.3 & 317,231 & 71.2 & 1.0 & 27.8 & 17,834 & 82.2 & 17.8 & - \\
\hline Goa & 151,475 & 92.7 & 1.5 & 5.8 & 14,496 & 91.0 & 2.9 & 6.1 & 4,869 & 90.4 & - & 9.6 \\
\hline Gujarat & $8,525,234$ & 73.9 & 2.5 & 23.6 & $2,197,728$ & 62.6 & 3.5 & 33.9 & $1,341,702$ & 65.0 & 3.2 & 31.7 \\
\hline Haryana & $4,505,066$ & 77.4 & 1.6 & 21.0 & $1,294,789$ & 59.3 & 1.8 & 38.9 & 86,277 & 45.3 & 7.0 & 47.7 \\
\hline Himachal Pradesh & $1,179,234$ & 87.0 & 3.1 & 9.9 & 388,976 & 77.3 & 5.8 & 16.8 & 33,845 & 71.9 & 9.3 & 18.9 \\
\hline Jammu \& Kashmir & 580,275 & 80.7 & 2.9 & 16.4 & 112,314 & 53.6 & 7.4 & 39.0 & 10,807 & 31.0 & 16.5 & 52.5 \\
\hline Karnataka & $9,707,474$ & 72.7 & 8.9 & 18.4 & $3,892,753$ & 63.1 & 11.4 & 25.5 & 667,825 & 63.8 & 12.2 & 24.0 \\
\hline Kerala & $4,746,301$ & 94.4 & 0.6 & 5.0 & $1,515,712$ & 92.5 & 0.9 & 6.6 & 45,495 & 65.1 & 10.1 & 24.8 \\
\hline Madhya Pradesh & $15,706,955$ & 60.5 & 5.1 & 34.4 & $7,241,792$ & 49.5 & 6.2 & 44.3 & $3,778,131$ & 43.2 & 10.2 & 46.7 \\
\hline Maharashtra & $16,339,118$ & 81.4 & 4.1 & 14.6 & $6,236,886$ & 70.0 & 6.8 & 23.2 & $1,566,908$ & 64.9 & 6.5 & 28.6 \\
\hline Orissa & $7,388,821$ & 64.6 & 5.2 & 30.2 & $4,040,662$ & 53.3 & 6.1 & 40.6 & $1,716,873$ & 44.4 & 10.4 & 45.2 \\
\hline Punjab & $4,180,277$ & 80.3 & 2.0 & 17.7 & 703,932 & 57.6 & 3.3 & 39.1 & 49,569 & 58.0 & 6.2 & 35.8 \\
\hline Rajasthan & $9,761,945$ & 59.6 & 9.5 & 30.9 & $2,879,674$ & 44.2 & 13.4 & 42.4 & $1,296,786$ & 38.0 & 23.9 & 38.1 \\
\hline Tamil Nadu & $11,553,496$ & 83.0 & 7.7 & 9.3 & $4,573,672$ & 78.7 & 9.2 & 12.1 & 215,528 & 84.3 & 3.1 & 12.6 \\
\hline Uttar Pradesh & $34,330,060$ & 61.2 & 3.2 & 35.6 & $16,745,831$ & 51.1 & 3.9 & 45.0 & 307,692 & 48.9 & 9.4 & 41.7 \\
\hline West Bengal & $16,191,944$ & 68.1 & 3.5 & 28.4 & $7,869,749$ & 56.5 & 4.3 & 39.1 & 977,947 & 48.4 & 4.7 & 46.9 \\
\hline
\end{tabular}

Sources: 1. Computed from NSS 61st Round for 2004-05 and NSS 50th Round for 1993-94

2. Chaudhri \& Jha, 'Child Poverty and Elementary Education in India', ASARC Working Paper 2011/04. 
Policy Insights from Household Data Analysis

Table A7R: Child population (5 to 14 years) in major states of rural India 2004-05 and 1993-94

a) 2004-05

\begin{tabular}{|c|c|c|c|c|c|c|c|c|c|c|c|c|}
\hline & \multicolumn{4}{|c|}{ Total } & \multicolumn{4}{|c|}{ Poverty } & \multicolumn{4}{|c|}{ Non-poverty } \\
\hline & $\begin{array}{c}\text { Child } \\
\text { population }\end{array}$ & $\begin{array}{l}\text { In schools } \\
\text { (\% of (1)) }\end{array}$ & $\begin{array}{l}\text { Child labor } \\
\text { (\% of (1)) }\end{array}$ & $\begin{array}{l}\text { No where } \\
(\% \text { of (1)) }\end{array}$ & $\begin{array}{c}\text { Child } \\
\text { population }\end{array}$ & $\begin{array}{l}\text { In schools } \\
(\% \text { of (5)) }\end{array}$ & $\begin{array}{l}\text { Child labor } \\
\text { (\% of (5)) }\end{array}$ & $\begin{array}{l}\text { No where } \\
\text { (\% of (5)) }\end{array}$ & $\begin{array}{c}\text { Child } \\
\text { population }\end{array}$ & $\begin{array}{l}\text { In schools } \\
\text { (\% of (9)) }\end{array}$ & $\begin{array}{l}\text { Child labor } \\
\text { (\% of (9)) }\end{array}$ & $\begin{array}{l}\text { No where } \\
\text { (\% of (9)) }\end{array}$ \\
\hline & (1) & $(2)$ & (3) & (4) & (5) & (6) & $(7)$ & (8) & (9) & (10) & (11) & (12) \\
\hline $\begin{array}{l}\text { All Rural India } \\
\text { States }\end{array}$ & $176,302,387$ & 80.3 & 2.6 & 17.1 & $52,917,403$ & 70.4 & 3.3 & 26.3 & $123,384,984$ & 84.5 & 23 & 13.2 \\
\hline Andhra Pradesh & $11,202,377$ & 86.5 & 6.9 & 6.6 & $1,544,729$ & 85.1 & 8.0 & 6.9 & $9,657,648$ & 86.7 & 6.8 & 6.5 \\
\hline Assam & $5,676,130$ & 87.1 & 1.6 & 11.3 & $1,374,278$ & 80.5 & 1.6 & 17.9 & $4,301,852$ & 89.3 & 1.6 & 9.1 \\
\hline Bihar & $23,123,106$ & 66.1 & 1.3 & 32.6 & $9,525,572$ & 53.6 & 1.8 & 44.6 & $13,597,534$ & 74.8 & 0.9 & 24.3 \\
\hline Dadra \& Nagar Haveli & 37,620 & 83.6 & 1.3 & 15.1 & 8,950 & 71.0 & - & 29.0 & 28,670 & 87.6 & 1.7 & 10.7 \\
\hline Delhi & 272,345 & 94.2 & - & 5.8 & 8,175 & 100.0 & - & - & 264,170 & 94.0 & - & 6.0 \\
\hline Goa & 113,015 & 95.0 & 3.5 & 1.5 & 4,674 & 100.0 & - & - & 108,341 & 94.8 & 3.6 & 1.6 \\
\hline Gujarat & $6,969,806$ & 82.8 & 2.2 & 14.9 & $1,385,383$ & 80.8 & 2.1 & 17.1 & $5,584,423$ & 83.3 & 2.2 & 14.4 \\
\hline Haryana & $3,560,588$ & 86.1 & 0.7 & 13.2 & 566,312 & 72.6 & 1.0 & 26.4 & $2,994,276$ & 88.6 & 0.7 & 10.7 \\
\hline Himachal Pradesh & $1,151,389$ & 94.9 & 1.1 & 4.0 & 139,659 & 84.3 & 4.2 & 11.5 & $1,011,730$ & 96.4 & 0.7 & 2.9 \\
\hline Jammu \& Kashmir & $1,122,248$ & 86.9 & 1.6 & 11.5 & 40,447 & 68.6 & 6.8 & 24.6 & $1,081,801$ & 87.6 & 1.4 & 11.0 \\
\hline Karnataka & $6,720,215$ & 85.9 & 5.4 & 8.7 & $1,647,628$ & 75.3 & 6.6 & 18.2 & $5,072,587$ & 89.3 & 5.1 & 5.6 \\
\hline Kerala & $5,410,020$ & 94.4 & 0.5 & 5.1 & $1,287,405$ & 86.9 & 1.2 & 11.8 & $4,122,615$ & 96.8 & 0.3 & 3.0 \\
\hline Madhya Pradesh & $16,831,846$ & 76.7 & 2.8 & 20.5 & $6,053,572$ & 68.6 & 3.3 & 28.1 & $10,778,274$ & 81.3 & 2.5 & 16.2 \\
\hline Maharashtra & $11,847,243$ & 87.3 & 3.5 & 9.2 & $3,475,659$ & 78.9 & 5.0 & 16.1 & $8,371,584$ & 90.8 & 2.9 & 6.4 \\
\hline Orissa & $6,941,652$ & 79.1 & 3.8 & 17.1 & $3,413,541$ & 72.9 & 4.7 & 22.4 & 3,528,111 & 85.1 & 3.0 & 11.9 \\
\hline Punjab & $3,597,599$ & 89.0 & 1.4 & 9.6 & 482,724 & 73.0 & 2.4 & 24.6 & $3,114,875$ & 91.5 & 1.2 & 7.2 \\
\hline Rajasthan & $11,373,576$ & 77.1 & 4.1 & 18.8 & $2,303,262$ & 68.0 & 6.1 & 25.9 & $9,070,314$ & 79.4 & 3.6 & 17.0 \\
\hline Tamil Nadu & $6,733,721$ & 95.8 & 1.4 & 2.7 & $1,732,297$ & 93.4 & 1.8 & 4.8 & $5,001,424$ & 96.7 & 1.3 & 2.0 \\
\hline Uttar Pradesh & $37,425,280$ & 77.1 & 1.9 & 21.0 & $12,470,817$ & 70.0 & 2.2 & 27.8 & $24,954,463$ & 80.7 & 1.7 & 17.6 \\
\hline West Bengal & $14,214,979$ & 82.2 & 2.3 & 15.5 & $5,228,570$ & 70.6 & 3.1 & 26.3 & 8,986,409 & 89.0 & 1.8 & 9.2 \\
\hline
\end{tabular}


Table A7R (continued)

b) 1993-94

\begin{tabular}{|c|c|c|c|c|c|c|c|c|c|c|c|c|}
\hline & \multicolumn{4}{|c|}{ Total } & \multicolumn{4}{|c|}{ Poverty } & \multicolumn{4}{|c|}{ Non-poverty } \\
\hline & $\begin{array}{c}\text { Child } \\
\text { population }\end{array}$ & $\begin{array}{c}\text { In schools (\% } \\
\text { of (1)) }\end{array}$ & $\begin{array}{l}\text { Child labor } \\
\text { (\% of (1)) }\end{array}$ & $\begin{array}{c}\text { No where (\% } \\
\text { of (1)) }\end{array}$ & $\begin{array}{c}\text { Child } \\
\text { population }\end{array}$ & $\begin{array}{l}\text { In schools } \\
\text { (\% of (5)) }\end{array}$ & $\begin{array}{l}\text { Child labor } \\
\text { (\% of (5)) }\end{array}$ & $\begin{array}{l}\text { No where } \\
\text { (\% of (5)) }\end{array}$ & $\begin{array}{c}\text { Child } \\
\text { population }\end{array}$ & $\begin{array}{l}\text { In schools } \\
\text { (\% of (9)) }\end{array}$ & $\begin{array}{l}\text { Child labor } \\
\text { (\% of (9)) }\end{array}$ & $\begin{array}{l}\text { No where } \\
\text { (\% of (9)) }\end{array}$ \\
\hline & (1) & (2) & (3) & (4) & (5) & (6) & (7) & (8) & (9) & (10) & (11) & (12) \\
\hline $\begin{array}{l}\text { All Rural India } \\
\text { States }\end{array}$ & $141,898,749$ & 64.3 & 5.6 & 30.1 & $60,440,528$ & 523 & 6.8 & 40.9 & $81,458,221$ & 73.2 & 4.8 & 220 \\
\hline Andhra Pradesh & $10,335,638$ & 59.7 & 16.0 & 24.3 & $2,032,725$ & 48.1 & 16.5 & 35.4 & 8,302,913 & 62.5 & 15.9 & 21.6 \\
\hline Assam & $4,615,385$ & 73.6 & 1.7 & 24.7 & $2,373,611$ & 65.7 & 2.3 & 32.0 & $2,241,774$ & 81.9 & 1.1 & 17.1 \\
\hline Bihar & $15,496,190$ & 50.6 & 3.2 & 46.2 & $9,657,010$ & 41.8 & 3.7 & 54.5 & $5,839,180$ & 65.1 & 2.4 & 32.5 \\
\hline Dadra \& Nagar Haveli & 24,766 & 58.8 & 1.7 & 39.6 & 16,075 & 52.0 & 1.3 & 46.7 & 8,691 & 71.2 & 2.4 & 26.4 \\
\hline Delhi & 182,936 & 91.6 & - & 8.4 & 4,292 & 100.0 & - & - & 178,644 & 91.4 & - & 8.6 \\
\hline Goa & 86,503 & 95.8 & 0.9 & 3.3 & 6,003 & 85.3 & - & 14.7 & 80,500 & 96.6 & 1.0 & 2.5 \\
\hline Gujarat & $5,807,528$ & 69.8 & 2.8 & 27.4 & 1,552,195 & 58.9 & 3.9 & 37.2 & $4,255,333$ & 73.8 & 2.4 & 23.8 \\
\hline Haryana & $3,417,769$ & 74.7 & 1.3 & 24.0 & 1,097,338 & 57.8 & 1.5 & 40.7 & $2,320,431$ & 82.7 & 1.3 & 16.0 \\
\hline Himachal Pradesh & $1,089,764$ & 86.5 & 3.2 & 10.4 & 369,753 & 76.8 & 5.9 & 17.3 & 720,011 & 91.4 & 1.8 & 6.8 \\
\hline Jammu \& Kashmir & 468,214 & 78.1 & 3.3 & 18.6 & 94,293 & 47.8 & 8.5 & 43.7 & 373,921 & 85.8 & 2.0 & 12.2 \\
\hline Karnataka & $7,029,534$ & 68.4 & 10.7 & 20.9 & $2,491,063$ & 55.4 & 14.1 & 30.4 & $4,538,471$ & 75.6 & 8.8 & 15.6 \\
\hline Kerala & $3,736,577$ & 94.2 & 0.5 & 5.3 & $1,121,372$ & 92.3 & 0.7 & 7.0 & $2,615,205$ & 95.0 & 0.5 & 4.6 \\
\hline Madhya Pradesh & $11,949,014$ & 53.9 & 6.3 & 39.8 & $5,413,469$ & 42.1 & 7.6 & 50.4 & $6,535,545$ & 63.7 & 5.3 & 31.0 \\
\hline Maharashtra & $10,529,057$ & 78.9 & 5.2 & 15.9 & $4,763,647$ & 68.4 & 7.8 & 23.8 & $5,765,410$ & 87.6 & 3.1 & 9.3 \\
\hline Orissa & $6,503,251$ & 62.8 & 5.5 & 31.6 & $3,639,695$ & 52.6 & 6.2 & 41.3 & $2,863,556$ & 75.8 & 4.8 & 19.4 \\
\hline Punjab & $2,974,573$ & 77.2 & 2.1 & 20.7 & 432,911 & 47.8 & 3.3 & 48.9 & $2,541,662$ & 82.2 & 1.9 & 15.9 \\
\hline Rajasthan & $7,637,553$ & 55.1 & 11.3 & 33.6 & $2,268,301$ & 40.4 & 16.0 & 43.6 & $5,369,252$ & 61.3 & 9.3 & 29.4 \\
\hline Tamil Nadu & $7,484,322$ & 80.1 & 9.3 & 10.6 & $3,179,614$ & 75.9 & 10.6 & 13.5 & $4,304,708$ & 83.2 & 8.3 & 8.5 \\
\hline Uttar Pradesh & $27,856,756$ & 58.1 & 3.4 & 38.5 & $12,879,904$ & 47.3 & 4.0 & 48.7 & $14,976,852$ & 67.4 & 2.8 & 29.7 \\
\hline West Bengal & $13,041,812$ & 65.1 & 3.5 & 31.4 & $6,299,570$ & 52.6 & 4.3 & 43.1 & $6,742,242$ & 76.8 & 2.8 & 20.4 \\
\hline
\end{tabular}

Sources: 1. Computed from NSS 61st Round for 2004-05 and NSS 50th Round for 1993-94

2. Chaudhri \& Jha, 'Child Poverty and Elementary Education in India', ASARC Working Paper 2011/04. 
Policy Insights from Household Data Analysis

TableA7U: Child population (5 to 14 years) in major states of urban India 2004-05 and 1993-94

a) 2004-05

\begin{tabular}{|c|c|c|c|c|c|c|c|c|c|c|c|c|}
\hline & \multicolumn{4}{|c|}{ Total } & \multicolumn{4}{|c|}{ Poverty } & \multicolumn{4}{|c|}{ Non-poverty } \\
\hline & $\begin{array}{c}\text { Child } \\
\text { population }\end{array}$ & $\begin{array}{l}\text { In schools } \\
\text { (\% of (1)) }\end{array}$ & $\begin{array}{l}\text { Child labor } \\
\text { (\% of (1)) }\end{array}$ & $\begin{array}{l}\text { No where } \\
\text { (\% of (1)) }\end{array}$ & $\begin{array}{c}\text { Child } \\
\text { population }\end{array}$ & $\begin{array}{l}\text { In schools } \\
\text { (\% of (5)) }\end{array}$ & $\begin{array}{l}\text { Child } \\
\text { labor } \\
\text { (\% of (5)) }\end{array}$ & $\begin{array}{l}\text { No where } \\
\text { (\% of (5)) }\end{array}$ & $\begin{array}{c}\text { Child } \\
\text { population }\end{array}$ & $\begin{array}{l}\text { In schools } \\
\text { (\% of (9)) }\end{array}$ & $\begin{array}{l}\text { Child labor } \\
\text { (\% of (9)) }\end{array}$ & $\begin{array}{l}\text { No where } \\
\text { (\% of (9)) }\end{array}$ \\
\hline & (1) & (2) & (3) & (4) & (5) & (6) & (7) & (8) & (9) & (10) & (11) & (12) \\
\hline $\begin{array}{l}\text { All Urban India } \\
\text { States }\end{array}$ & $49,831,043$ & 88.5 & 19 & 9.7 & $16,734,089$ & 77.4 & 3.6 & 19.0 & $33,096,954$ & 94.1 & 10 & 4.9 \\
\hline Andhra Pradesh & $3,650,692$ & 91.1 & 3.0 & 5.9 & $1,168,036$ & 86.6 & 5.2 & 8.2 & $2,482,656$ & 93.2 & 1.9 & 4.9 \\
\hline Assam & 501,328 & 87.0 & 0.9 & 12.1 & 17,330 & 47.9 & 0.3 & 51.8 & 483,998 & 88.4 & 0.9 & 10.7 \\
\hline Bihar & $2,592,356$ & 82.9 & 1.3 & 15.8 & 823,313 & 63.8 & 2.8 & 33.4 & $1,769,043$ & 91.7 & 0.7 & 7.6 \\
\hline Dadra \& Nagar Haveli & 2,985 & 91.2 & 5.2 & 3.7 & 1,041 & 79.0 & 14.8 & 6.2 & 1,944 & 97.7 & - & 2.3 \\
\hline Delhi & $2,021,538$ & 89.8 & 0.3 & 9.9 & 342,283 & 75.2 & 1.1 & 23.7 & $1,679,255$ & 92.7 & 0.1 & 7.1 \\
\hline Goa & 58,074 & 93.8 & 1.2 & 5.0 & 17,499 & 88.2 & 1.5 & 10.2 & 40,575 & 96.2 & 1.0 & 2.8 \\
\hline Gujarat & 3,074,061 & 91.8 & 1.6 & 6.6 & 468,796 & 74.7 & 4.5 & 20.8 & $2,605,265$ & 94.9 & 1.1 & 4.0 \\
\hline Haryana & $1,228,731$ & 90.5 & 0.6 & 8.9 & 227,830 & 67.6 & 1.1 & 31.3 & $1,000,901$ & 95.7 & 0.5 & 3.8 \\
\hline Himachal Pradesh & 100,166 & 95.9 & 0.1 & 4.0 & 14,227 & 99.7 & - & 0.3 & 85,939 & 95.3 & 0.1 & 4.6 \\
\hline Jammu \& Kashmir & 359,918 & 92.0 & 4.3 & 3.7 & 31,384 & 69.7 & 21.5 & 8.9 & 328,534 & 94.1 & 2.6 & 3.2 \\
\hline Karnataka & $2,763,022$ & 94.1 & 0.9 & 5.0 & $1,071,448$ & 89.8 & 1.3 & 8.9 & $1,691,574$ & 96.9 & 0.6 & 2.5 \\
\hline Kerala & $1,588,075$ & 96.7 & 0.2 & 3.1 & 428,757 & 92.6 & 0.1 & 7.2 & $1,159,318$ & 98.2 & 0.3 & 1.5 \\
\hline Madhya Pradesh & $3,910,408$ & 89.0 & 1.5 & 9.5 & $2,002,262$ & 82.5 & 2.6 & 14.9 & $1,908,146$ & 95.9 & 0.3 & 3.8 \\
\hline Maharashtra & $6,820,226$ & 92.3 & 0.8 & 6.9 & $2,924,474$ & 87.4 & 1.2 & 11.5 & $3,895,752$ & 96.1 & 0.5 & 3.5 \\
\hline Orissa & 966,930 & 87.9 & 1.7 & 10.5 & 511,447 & 78.2 & 3.1 & 18.7 & 455,483 & 98.7 & - & 1.3 \\
\hline Punjab & $1,423,222$ & 89.0 & 0.7 & 10.3 & 117,985 & 48.9 & 1.5 & 49.6 & $1,305,237$ & 92.6 & 0.6 & 6.7 \\
\hline Rajasthan & $3,222,609$ & 81.3 & 2.8 & 15.9 & $1,271,820$ & 65.2 & 5.0 & 29.8 & 1,950,789 & 91.8 & 1.3 & 6.9 \\
\hline Tamil Nadu & $3,629,125$ & 96.7 & 1.4 & 2.0 & $1,043,658$ & 94.0 & 2.6 & 3.3 & $2,585,467$ & 97.7 & 0.8 & 1.4 \\
\hline Uttar Pradesh & $8,112,658$ & 79.6 & 3.3 & 17.1 & $3,416,212$ & 67.3 & 5.3 & 27.4 & $4,696,446$ & 88.5 & 1.8 & 9.7 \\
\hline West Bengal & $3,113,514$ & 86.0 & 3.9 & 10.1 & 632,791 & 70.4 & 9.2 & 20.4 & $2,480,723$ & 90.0 & 2.5 & 7.5 \\
\hline
\end{tabular}


Table A7U (continued)

b) 1993-94

\begin{tabular}{|c|c|c|c|c|c|c|c|c|c|c|c|c|}
\hline & \multicolumn{4}{|c|}{ Total } & \multicolumn{4}{|c|}{ Poverty } & \multicolumn{4}{|c|}{ Non-poverty } \\
\hline & $\begin{array}{c}\text { Child } \\
\text { population }\end{array}$ & $\begin{array}{c}\text { In schools (\% } \\
\text { of (1)) }\end{array}$ & $\begin{array}{l}\text { Child labor } \\
\text { (\% of (1)) }\end{array}$ & $\begin{array}{l}\text { No where } \\
\text { (\% of (1)) }\end{array}$ & $\begin{array}{c}\text { Child } \\
\text { population }\end{array}$ & $\begin{array}{l}\text { In schools } \\
\text { (\% of (5)) }\end{array}$ & $\begin{array}{l}\text { Child labor } \\
\text { (\% of (5)) }\end{array}$ & $\begin{array}{l}\text { No where } \\
\text { (\% of (5)) }\end{array}$ & $\begin{array}{c}\text { Child } \\
\text { population }\end{array}$ & $\begin{array}{l}\text { In schools } \\
\text { (\% of (9)) }\end{array}$ & $\begin{array}{c}\text { Child } \\
\text { labor (\% } \\
\text { of (9)) }\end{array}$ & $\begin{array}{l}\text { No where } \\
\text { (\% of (9)) }\end{array}$ \\
\hline & (1) & (2) & (3) & (4) & (5) & (6) & (7) & (8) & (9) & (10) & (11) & (12) \\
\hline $\begin{array}{l}\text { All Urban India } \\
\text { States }\end{array}$ & $43,407,524$ & 81.9 & 28 & 15.3 & $17,307,421$ & 710 & 4.1 & 24.9 & $26,100,103$ & 89.1 & 2.0 & 8.9 \\
\hline Andhra Pradesh & $3,600,256$ & 81.2 & 5.9 & 12.9 & $1,607,981$ & 71.7 & 8.3 & 20.0 & $1,992,275$ & 88.8 & 4.0 & 7.2 \\
\hline Assam & 415,827 & 81.2 & 3.7 & 15.1 & 48,644 & 68.8 & 6.6 & 24.6 & 367,183 & 82.8 & 3.3 & 13.9 \\
\hline Bihar & $2,186,129$ & 74.6 & 1.2 & 24.2 & 885,275 & 58.9 & 1.8 & 39.3 & $1,300,854$ & 85.2 & 0.8 & 13.9 \\
\hline Dadra \& Nagar Haveli & 1,826 & 49.9 & 1.0 & 49.1 & 859 & 54.8 & 2.1 & 43.1 & 967 & 45.5 & - & 54.5 \\
\hline Delhi & $1,434,215$ & 82.9 & 0.9 & 16.2 & 312,939 & 70.8 & 1.0 & 28.2 & $1,121,276$ & 86.3 & 0.9 & 12.9 \\
\hline Goa & 64,972 & 88.6 & 2.3 & 9.1 & 8,493 & 95.0 & 5.0 & - & 56,479 & 87.6 & 1.9 & 10.4 \\
\hline Gujarat & $2,717,706$ & 82.7 & 1.7 & 15.6 & 645,533 & 71.5 & 2.6 & 25.9 & $2,072,173$ & 86.2 & 1.4 & 12.4 \\
\hline Haryana & $1,087,297$ & 85.9 & 2.2 & 11.8 & 197,451 & 67.7 & 3.5 & 28.8 & 889,846 & 90.0 & 2.0 & 8.1 \\
\hline Himachal Pradesh & 89,470 & 93.6 & 2.1 & 4.3 & 19,223 & 88.2 & 4.4 & 7.4 & 70,247 & 95.1 & 1.5 & 3.4 \\
\hline Jammu \& Kashmir & 112,061 & 91.5 & 1.1 & 7.5 & 18,021 & 83.8 & 1.6 & 14.5 & 94,040 & 92.9 & 0.9 & 6.1 \\
\hline Karnataka & $2,677,940$ & 84.0 & 4.3 & 11.7 & $1,401,690$ & 76.8 & 6.6 & 16.6 & $1,276,250$ & 91.9 & 1.7 & 6.4 \\
\hline Kerala & $1,009,724$ & 95.3 & 0.8 & 3.9 & 394,340 & 93.3 & 1.4 & 5.4 & 615,384 & 96.6 & 0.4 & 2.9 \\
\hline Madhya Pradesh & $3,757,941$ & 81.6 & 1.2 & 17.2 & $1,828,323$ & 71.7 & 2.0 & 26.3 & $1,929,618$ & 90.9 & 0.4 & 8.7 \\
\hline Maharashtra & $5,810,061$ & 85.8 & 2.0 & 12.2 & $1,473,239$ & 74.9 & 3.6 & 21.4 & $4,336,822$ & 89.5 & 1.4 & 9.1 \\
\hline Orissa & 885,570 & 77.5 & 2.9 & 19.6 & 400,967 & 60.0 & 5.6 & 34.3 & 484,603 & 92.1 & 0.6 & 7.4 \\
\hline Punjab & $1,205,704$ & 88.0 & 1.8 & 10.2 & 271,021 & 73.2 & 3.3 & 23.5 & 934,683 & 92.3 & 1.3 & 6.3 \\
\hline Rajasthan & $2,124,392$ & 75.8 & 2.8 & 21.4 & 611,373 & 58.2 & 3.8 & 38.0 & $1,513,019$ & 83.0 & 2.4 & 14.7 \\
\hline Tamil Nadu & $4,069,174$ & 88.3 & 4.9 & 6.8 & $1,394,058$ & 85.1 & 6.0 & 8.9 & $2,675,116$ & 89.9 & 4.3 & 5.7 \\
\hline Uttar Pradesh & $6,473,304$ & 74.3 & 2.7 & 22.9 & $3,865,927$ & 63.8 & 3.5 & 32.8 & $2,607,377$ & 90.0 & 1.7 & 8.3 \\
\hline West Bengal & $3,150,132$ & 80.3 & 3.6 & 16.1 & $1,570,179$ & 72.2 & 4.5 & 23.3 & $1,579,953$ & 88.3 & 2.7 & 9.0 \\
\hline
\end{tabular}

Sources: 1. Computed from NSS 61st Round for 2004-05 and NSS 50th Round for 1993-94

2. Chaudhri \& Jha, 'Child Poverty and Elementary Education in India', ASARC Working Paper 2011/04. 
Policy Insights from Household Data Analysis

Table A8: Change in children's participation in schooling, child labour and non-participation from 1993-94 to 2004-05 in major states of urban India

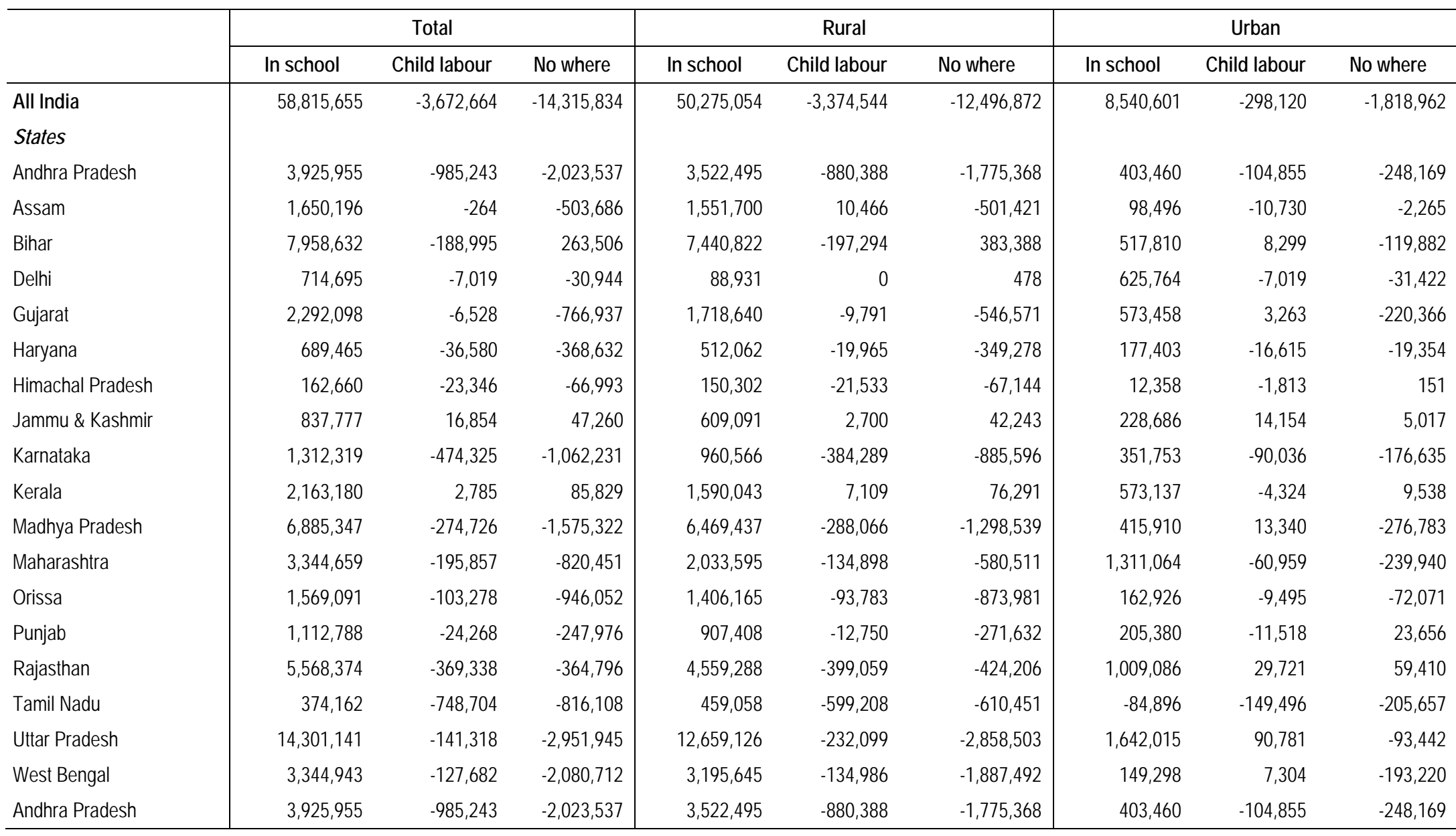

Sources: 1. Computed from NSS 61st Round for 2004-05 and NSS 50th Round for 1993-94

2. Chaudhri \& Jha, 'Child Poverty and Eementary Education in India', ASARC Working Paper 2011/04. 
Child Poverty and Compulsory Elementary Education in India:

Table A9: Estimates of Child Poverty using the Absolute Poverty Line in India

\begin{tabular}{|c|c|c|c|c|c|c|c|c|c|}
\hline & \multicolumn{3}{|c|}{ 2004-05 } & \multicolumn{3}{|c|}{ 1993-94 } & \multicolumn{3}{|c|}{ Change (\%) } \\
\hline & $0-4$ & $5-9$ & $0-14$ & $0-4$ & $5-9$ & $0-14$ & $0-4$ & $5-9$ & $0-14$ \\
\hline All India & 33.77 & 33.84 & 31.72 & 46.07 & 45.3 & 43.4 & -26.7 & -25.3 & -26.8 \\
\hline \multicolumn{10}{|l|}{ States } \\
\hline Andhra Pradesh & 16.23 & 18.58 & 17.67 & 31.33 & 29.38 & 27.85 & -48.2 & -36.8 & -36.6 \\
\hline Assam & 24.43 & 26.19 & 23.07 & 53.72 & 51.74 & 49.81 & -54.5 & -49.4 & -53.7 \\
\hline Bihar & 44.42 & 43.53 & 41.65 & 65.80 & 63.06 & 61.85 & -32.5 & -31.0 & -32.7 \\
\hline Dadra \& Nagar Haveli & 29.56 & 32.32 & 26.47 & 64.52 & 72.07 & 64.00 & -54.2 & -55.2 & -58.6 \\
\hline Delhi & 17.43 & 15.46 & 15.89 & 22.30 & 23.46 & 20.55 & -21.9 & -34.1 & -22.7 \\
\hline Gujarat & 18.2 & 21.1 & 18.38 & 29.79 & 29.24 & 27.18 & -38.9 & -27.8 & -32.4 \\
\hline Haryana & 20.08 & 19.98 & 17.72 & 33.19 & 30.61 & 30.27 & -39.5 & -34.7 & -41.5 \\
\hline Himachal Pradesh & 12.91 & 13.27 & 12.48 & 40.17 & 35.78 & 35.27 & -67.9 & -62.9 & -64.6 \\
\hline Jammu \& Kashmir & 4.816 & 5.608 & 4.838 & 21.71 & 21.62 & 20.18 & -77.8 & -74.1 & -76.0 \\
\hline Karnataka & 30.04 & 32.17 & 29.09 & 43.08 & 42.23 & 41.06 & -30.3 & -23.8 & -29.1 \\
\hline Kerala & 26.56 & 27.48 & 25.18 & 34.96 & 33.66 & 32.80 & -24.0 & -18.4 & -23.2 \\
\hline Madhya Pradesh & 42.8 & 42.48 & 40.05 & 50.92 & 49.07 & 47.78 & -15.9 & -13.4 & -16.2 \\
\hline Maharashtra & 39.54 & 36.87 & 35.89 & 42.99 & 43.34 & 39.78 & -8.0 & -14.9 & -9.8 \\
\hline Orissa & 55.34 & 53.44 & 51.44 & 59.32 & 59.87 & 56.22 & -6.7 & -10.7 & -8.5 \\
\hline Punjab & 14.37 & 14.57 & 12.66 & 20.84 & 18.41 & 18.19 & -31.1 & -20.8 & -30.4 \\
\hline Rajasthan & 26.35 & 26.99 & 25.07 & 34.13 & 32.39 & 31.20 & -22.8 & -16.7 & -19.6 \\
\hline Tamil Nadu & 25.5 & 28.95 & 26.4 & 36.92 & 41.21 & 38.74 & -30.9 & -29.7 & -31.8 \\
\hline Uttar Pradesh & 37.43 & 37.45 & 35.69 & 52.48 & 51.25 & 50.11 & -28.7 & -26.9 & -28.8 \\
\hline West Bengal & 38.84 & 38.05 & 35.26 & 54.38 & 52.34 & 50.40 & -28.6 & -27.3 & -30.0 \\
\hline
\end{tabular}

Sources: 1. Computed from NSS 61st Round for 2004-05 and NSS 50th Round for 1993-94

2. Chaudhri \& Jha, 'Child Poverty and Elementary Education in India', ASARC Working Paper 2011/04. 
Table A9R

Estimates of Child Poverty using the Absolute Poverty Line in Rural India

\begin{tabular}{|c|c|c|c|c|c|c|c|c|c|}
\hline & \multicolumn{3}{|c|}{ 2004-05 } & \multicolumn{3}{|c|}{ 1993-94 } & \multicolumn{3}{|c|}{ Change (\%) } \\
\hline & $0-4$ & $5-9$ & $0-14$ & $0-4$ & $5-9$ & $0-14$ & $0-4$ & $5-9$ & $0-14$ \\
\hline All Rural India & 33.27 & 33.25 & 31.03 & 46.77 & 46.06 & 44.04 & -28.9 & -27.8 & -29.5 \\
\hline \multicolumn{10}{|l|}{ States } \\
\hline Andhra Pradesh & 11.64 & 14.14 & 13.15 & 25.08 & 23.09 & 21.48 & -53.6 & -38.8 & -38.8 \\
\hline Assam & 25.99 & 27.96 & 24.72 & 57.41 & 54.62 & 53.21 & -54.7 & -48.8 & -53.5 \\
\hline Bihar & 44.86 & 44.56 & 42.46 & 67.56 & 65.64 & 64.24 & -33.6 & -32.1 & -33.9 \\
\hline Dadra \& Nagar Haveli & 31.97 & 32.21 & 26.78 & 65.86 & 73.23 & 65.27 & -51.5 & -56.0 & -59.0 \\
\hline Delhi & 4.85 & 4.29 & 3.54 & 3.18 & 3.38 & 2.70 & 52.8 & 27.0 & 31.3 \\
\hline Gujarat & 19.27 & 22.65 & 19.67 & 31.92 & 29.59 & 28.57 & -39.7 & -23.4 & -31.1 \\
\hline Haryana & 20.00 & 19.33 & 17.28 & 35.97 & 33.59 & 33.46 & -44.4 & -42.4 & -48.3 \\
\hline Himachal Pradesh & 11.67 & 13.37 & 11.99 & 41.46 & 36.73 & 36.34 & -71.9 & -63.6 & -67.0 \\
\hline Jammu \& Kashmir & 4.02 & 4.57 & 3.72 & 24.62 & 23.25 & 21.72 & -83.7 & -80.4 & -82.9 \\
\hline Karnataka & 28.17 & 29.10 & 25.61 & 39.29 & 38.69 & 36.69 & -28.3 & -24.8 & -30.2 \\
\hline Kerala & 25.72 & 27.21 & 24.42 & 33.68 & 31.19 & 31.03 & -23.6 & -12.7 & -21.3 \\
\hline Madhya Pradesh & 40.61 & 40.38 & 37.39 & 50.04 & 48.55 & 46.99 & -18.8 & -16.8 & -20.4 \\
\hline Maharashtra & 34.93 & 31.66 & 31.02 & 49.29 & 51.03 & 46.66 & -29.1 & -38.0 & -33.5 \\
\hline Orissa & 55.16 & 53.10 & 51.06 & 60.41 & 61.35 & 57.45 & -8.7 & -13.4 & -11.1 \\
\hline Punjab & 16.21 & 16.21 & 14.23 & 18.04 & 16.18 & 15.75 & -10.1 & 0.2 & -9.7 \\
\hline Rajasthan & 22.04 & 22.73 & 20.81 & 34.45 & 32.57 & 31.46 & -36.0 & -30.2 & -33.8 \\
\hline Tamil Nadu & 25.88 & 27.59 & 25.77 & 39.02 & 45.25 & 41.35 & -33.7 & -39.0 & -37.7 \\
\hline Uttar Pradesh & 36.32 & 35.94 & 34.28 & 49.67 & 48.86 & 47.49 & -26.9 & -26.4 & -27.8 \\
\hline West Bengal & 43.60 & 41.21 & 38.71 & 54.29 & 52.15 & 50.21 & -19.7 & -21.0 & -22.9 \\
\hline
\end{tabular}

Sources: 1. Computed from NSS 61st Round for 2004-05 and NSS 50th Round for 1993-94

2. Chaudhri \& Jha, 'Child Poverty and Elementary Education in India', ASARC Working Paper 2011/04. 
Table A9U

Estimates of Child Poverty using the Absolute Poverty Line in Urban India

\begin{tabular}{|c|c|c|c|c|c|c|c|c|c|}
\hline & \multicolumn{3}{|c|}{ 2004-05 } & \multicolumn{3}{|c|}{$1993-94$} & \multicolumn{3}{|c|}{ Change (\%) } \\
\hline & $0-4$ & $5-9$ & $0-14$ & $0-4$ & $5-9$ & $0-14$ & $0-4$ & $5-9$ & $0-14$ \\
\hline All Urban India & 35.68 & 36.05 & 34.21 & 43.49 & 42.56 & 41.02 & -18.0 & -15.3 & -16.6 \\
\hline States & & & & & & & & & \\
\hline Andhra Pradesh & 31.42 & 32.64 & 31.83 & 50.17 & 48.03 & 46.45 & -37.4 & -32.1 & -31.5 \\
\hline Assam & 5.89 & 4.84 & 4.13 & 12.32 & 13.96 & 11.88 & -52.2 & -65.3 & -65.3 \\
\hline Bihar & 39.05 & 33.27 & 33.79 & 50.15 & 43.56 & 43.55 & -22.1 & -23.6 & -22.4 \\
\hline Dadra \& Nagar Haveli & 11.05 & 33.47 & 23.30 & 47.62 & 54.00 & 47.27 & -76.8 & -38.0 & -50.7 \\
\hline Delhi & 19.19 & 16.93 & 17.57 & 25.84 & 26.92 & 23.18 & -25.7 & -37.1 & -24.2 \\
\hline Gujarat & 15.42 & 17.47 & 15.30 & 24.80 & 28.42 & 24.10 & -37.8 & -38.5 & -36.5 \\
\hline Haryana & 20.34 & 22.00 & 19.07 & 23.53 & 20.87 & 19.92 & -13.6 & 5.4 & -4.2 \\
\hline Himachal Pradesh & 25.15 & 12.11 & 17.86 & 22.27 & 22.55 & 21.72 & 12.9 & -46.3 & -17.7 \\
\hline Jammu \& Kashmir & 7.88 & 8.58 & 8.52 & 9.21 & 14.24 & 13.70 & -14.5 & -39.8 & -37.9 \\
\hline Karnataka & 34.16 & 39.27 & 37.29 & 54.02 & 51.79 & 52.86 & -36.8 & -24.2 & -29.4 \\
\hline Kerala & 29.55 & 28.38 & 27.80 & 39.04 & 42.65 & 39.05 & -24.3 & -33.5 & -28.8 \\
\hline Madhya Pradesh & 52.74 & 52.61 & 51.66 & 54.21 & 50.93 & 50.43 & -2.7 & 3.3 & 2.4 \\
\hline Maharashtra & 47.05 & 46.41 & 44.19 & 29.12 & 28.22 & 26.51 & 61.6 & 64.5 & 66.7 \\
\hline Orissa & 56.59 & 55.88 & 54.11 & 50.29 & 47.93 & 46.82 & 12.5 & 16.6 & 15.6 \\
\hline Punjab & 9.66 & 10.46 & 8.69 & 28.32 & 23.88 & 24.39 & -65.9 & -56.2 & -64.4 \\
\hline Rajasthan & 43.40 & 42.10 & 40.61 & 32.89 & 31.76 & 30.22 & 31.9 & 32.6 & 34.4 \\
\hline Tamil Nadu & 24.85 & 31.43 & 27.54 & 32.57 & 32.97 & 33.75 & -23.7 & -4.7 & -18.4 \\
\hline Uttar Pradesh & 43.31 & 45.02 & 42.46 & 65.99 & 61.84 & 61.85 & -34.4 & -27.2 & -31.4 \\
\hline West Bengal & 18.83 & 22.21 & 19.87 & 54.87 & 53.26 & 51.21 & -65.7 & -58.3 & -61.2 \\
\hline
\end{tabular}

Sources: 1. Computed from NSS 61st Round for 2004-05 and NSS 50th Round for 1993-94

2. Chaudhri \& Jha, 'Child Poverty and Elementary Education in India', ASARC Working Paper 2011/04. 